تعزيز القدرة التنافسية للمؤسسات الصغيرة والمتوسطة كآلية لتفعيل دورها التنموي "دراسة عينة من المؤسسات الصغيرة والمتوسطة "

* غياط شريف (1)، مكاحلية محي الدين (2)

\author{
(1) جامعة 1 ماي 0 9 1 1، الجزائر

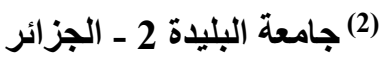 \\ *cghiat@yahoo.fr
}

الملخص

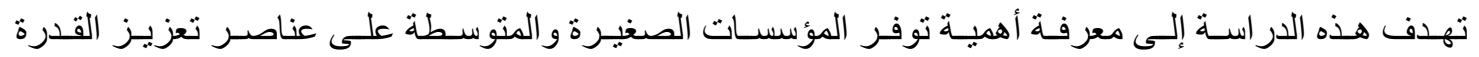

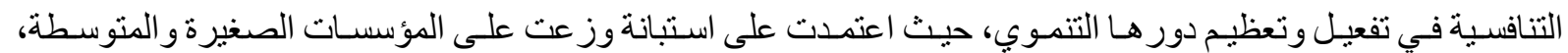

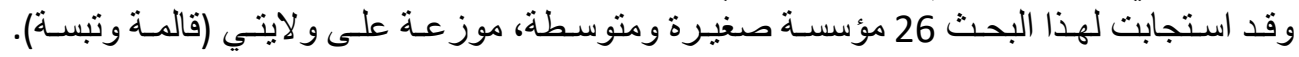

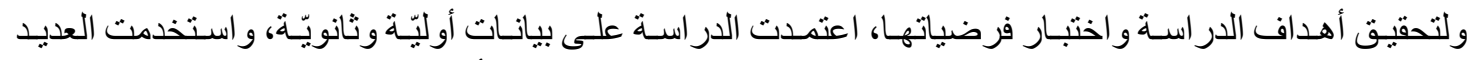

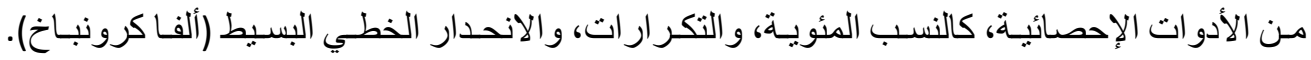

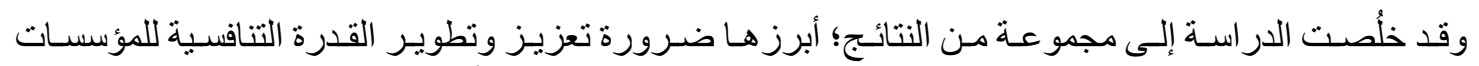

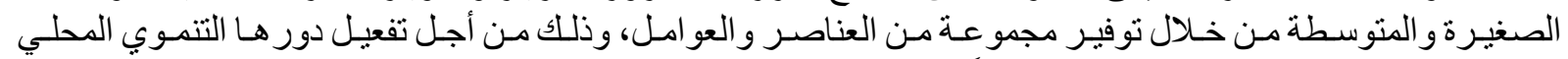
على مسـتوى و لايتي (قالمـة وتبسـة)، وصـو لاً إلى تجسيد التنميـة الوطنيـة الثـاملة.

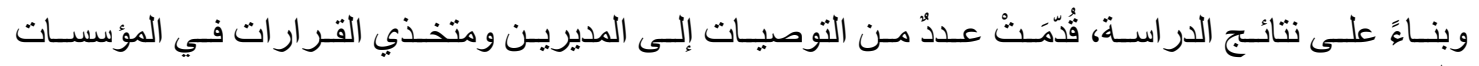
موضـوع الدراســة.

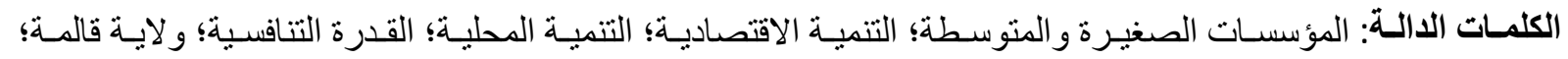
و لايـة تبســة. 
شريف ، محي الدين

\title{
Enhancing the competitiveness of small and medium companies mechanism to activate their development role
}

\author{
"Study a sample of small and medium companies"
}

\author{
*Ghiat Cherif ${ }^{(1)}$, Mukahlia Mohyaddine ${ }^{(2)}$ \\ (1) University of 8 May 1945 - Algeria \\ (2) Blida University 2 - Algeria
}

*cghiat@yahoo.fr

\begin{abstract}
The study aims to show the importance of existing factors of enhancing competitiveness in SMEs in order for activating their development role. The study adopts questionnaire methodology that distributed to a number of small and medium companies, where 26 companies, in Guelma and Tebessa cities, responded to the questionnaire. To achieve the objectives of the study and examine its hypotheses, it relied on primary and secondary data along with using many statistical tools such as percentages, repetitions, simple linear regression (Alpha Kronbach). The study concludes a set of findings, most notably the necessity to enhance and develop the competitiveness of SMEs through providing a range of fundamental elements and factors. This is to activate their development role locally at the level of Guelma and Tebessa cities reaching to comprehensive national development. Based on the results, the study offers a number of recommendations to the managers and decision makers in the organizations subject matter of this study.
\end{abstract}

Keywords: small and medium-sized enterprises; economic development; local development; competitiveness; Guelma; Tebessa.

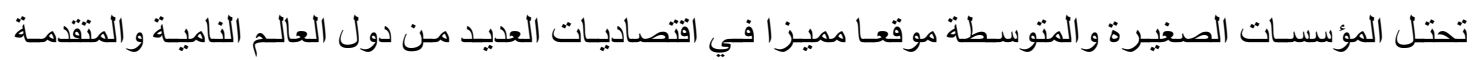

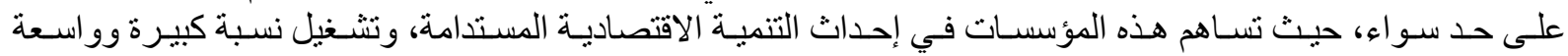
مـن اليـد العاملــة.

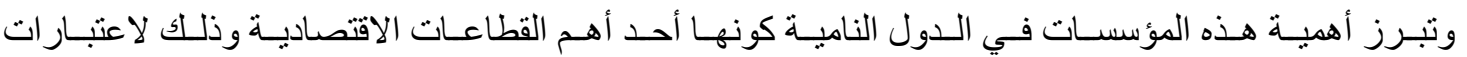

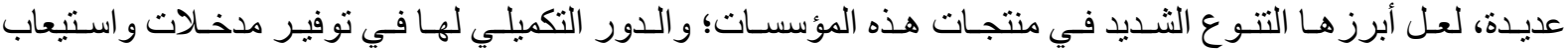

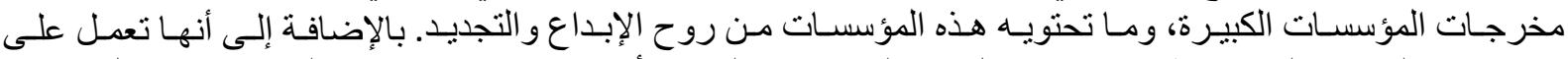

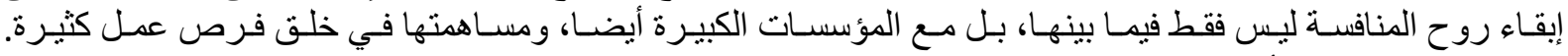

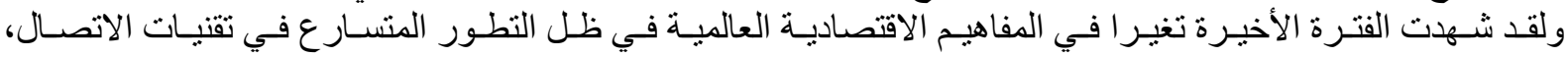

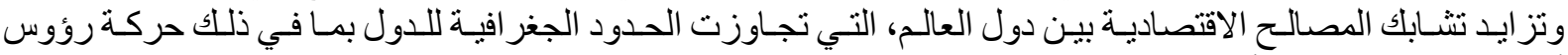

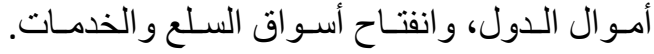
و انعكست هــه التحـو لات على أسـواق الهـال، و التجــارة الخارجيـة، والهيـاكل الاقتصاديـة، و التشـريعات في 


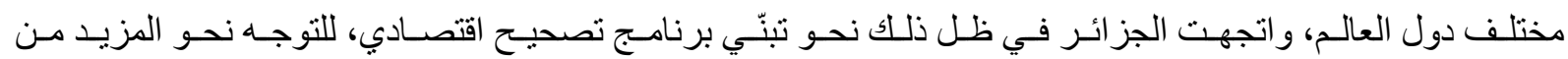

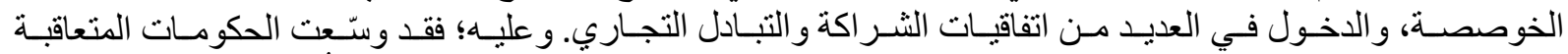

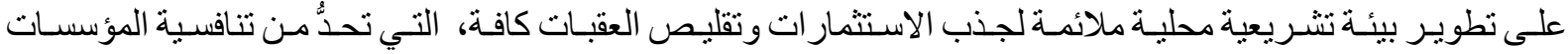
المحليـة.

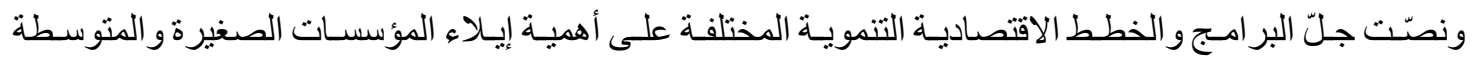

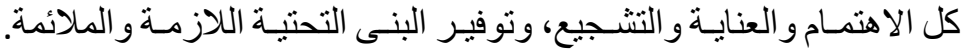

مشكلة الدراسة

لا ريب في أن المؤسسـات الصغيرة و المتوسطة أصبحت تعدّ في الوقت الر اهـن مـن أبرز الدعامـات و الركائز

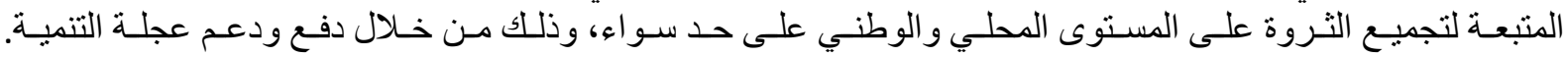

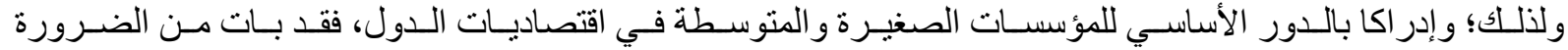

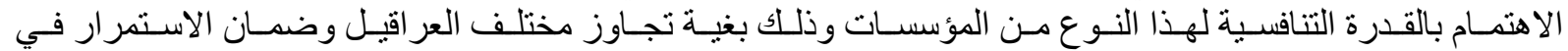

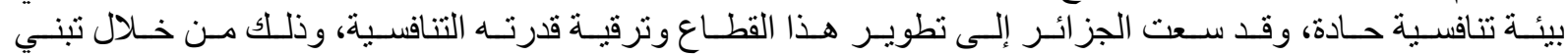

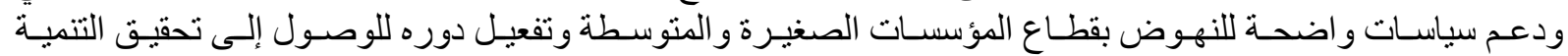

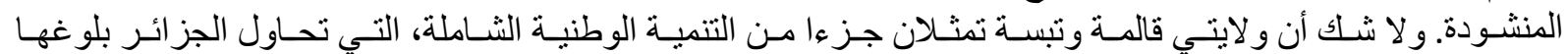

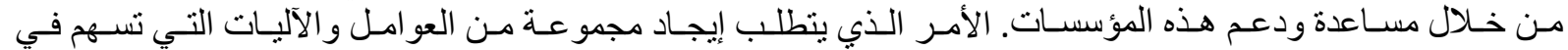

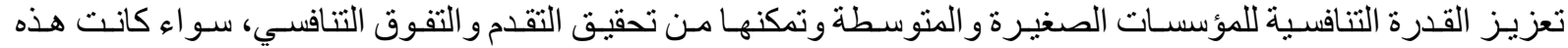

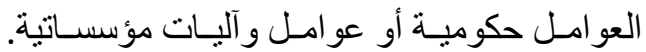
تأسيسا على ما تقدم، فإن إنشالية هذه الدراسة تتمحور حول التساؤل الرئيس الآتي:

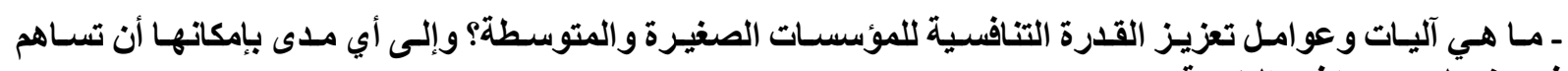
في تفعيل دور هـا في التنميـة نعزيـ

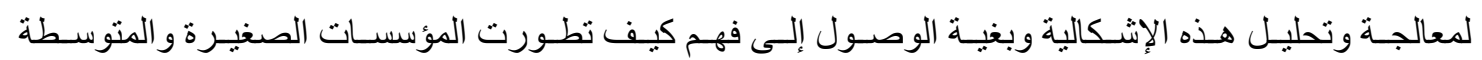

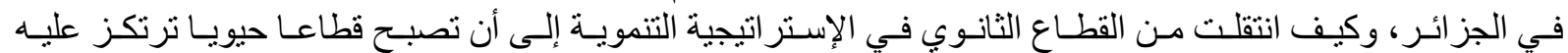

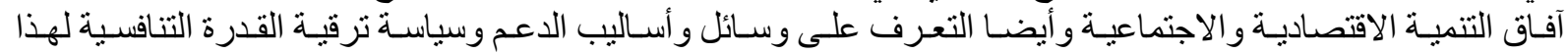

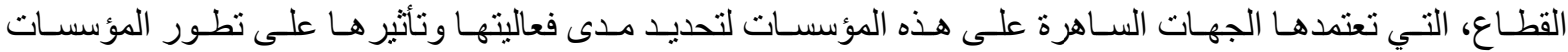

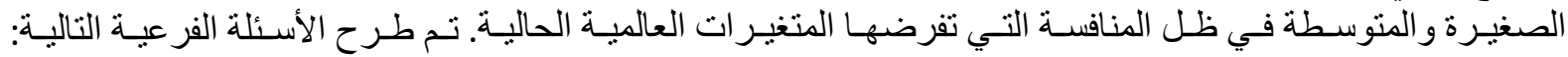

1. مـا هـي أبرز العناصـر التـي تسـاهم في دعم وتعزيز القدرة التنافسية للمؤسسـات الصغيرة و المتوسطة، ومـا أهينهـا

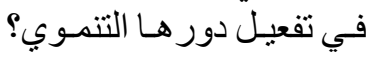

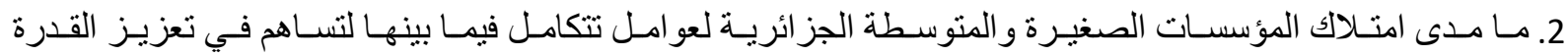
التنافسبـة مبد؟

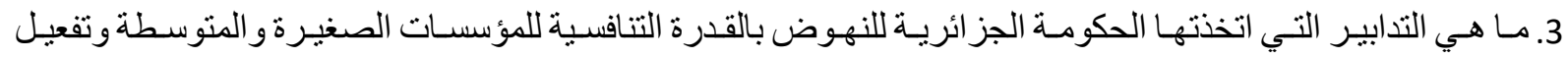

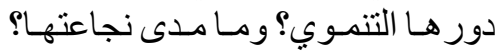

أهداف الدراسة: تهدف هذه الدر اسة إلى تحقيق ما يلي:

الإلمام بمختلف عناصر تعزيز وتطوير القدرة التنافسية المنوفرة في المؤسسات الصغيرة والمتوسطة الجزائرية.

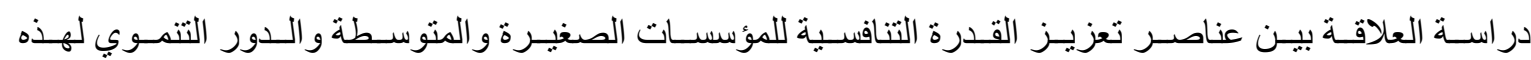
المؤسسـات.

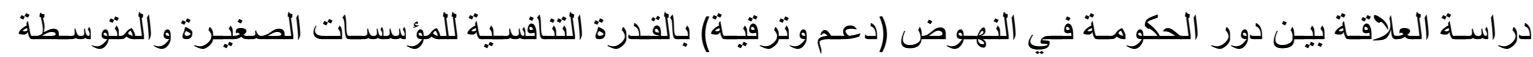

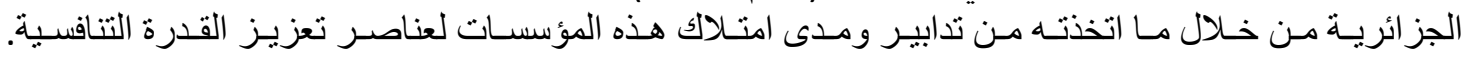

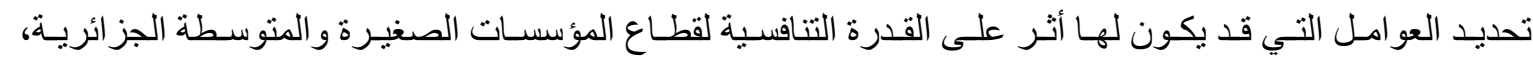

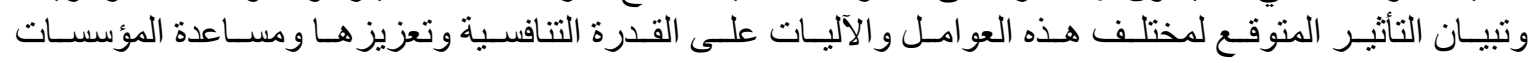




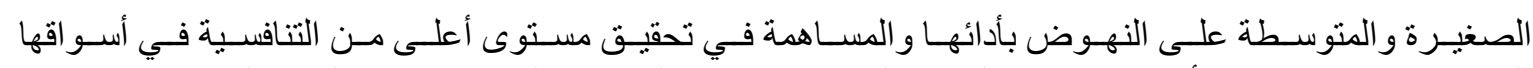

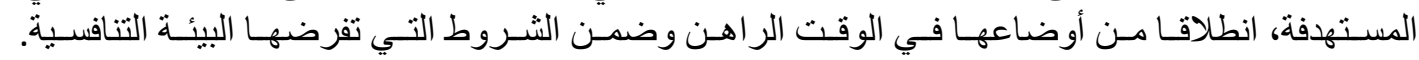

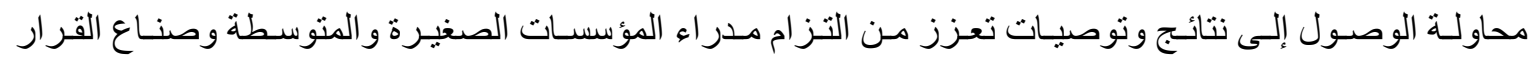

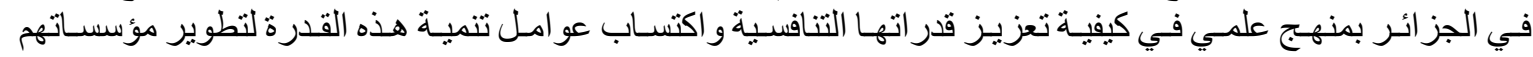

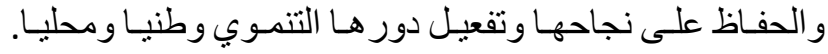

\section{فرضيات الاراسة:}

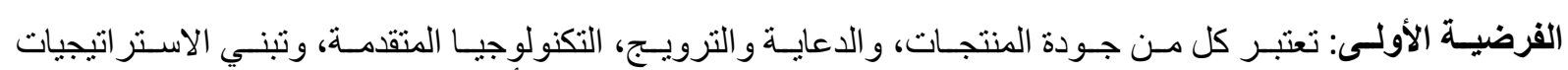

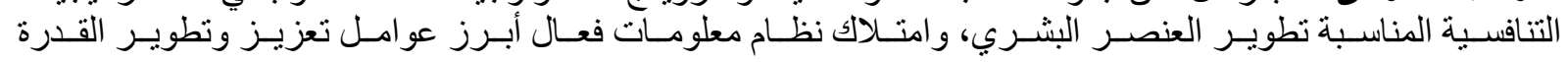

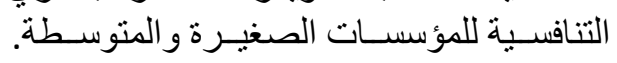
الفرضيـة الثانيـة: القدرة التنافسـية للمؤسسـات الصغيـرة والمتوسـة لهـا دور و أهميـة كبيـرة في تفعيـل وتعظيـم الـدور التنمـوي لهـذه المؤسسـات.

الفرضية الثالثة: لا تمتلك المؤسسات الصغيرة و المنوسطة الجز ائرية معظم عو امل وعناصر تعزيز القدرة التنافسية.

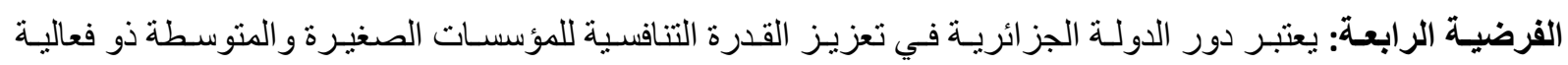

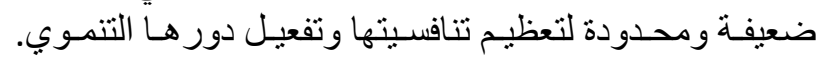

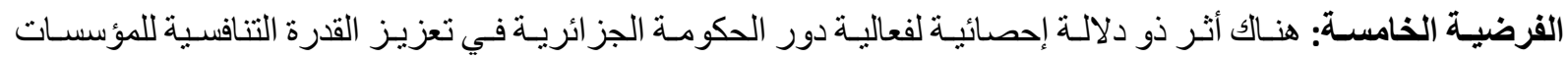

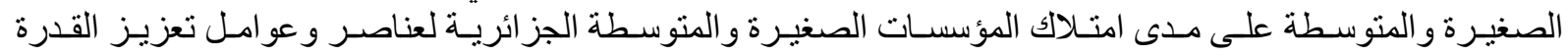

التنافسية.

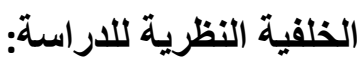

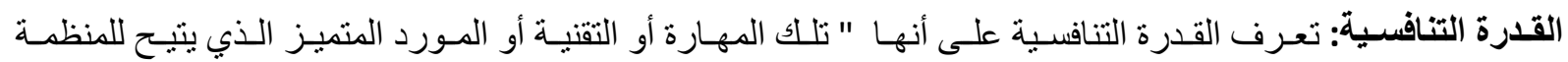

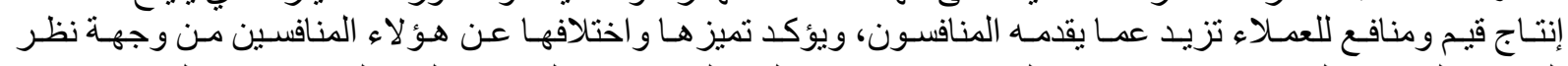

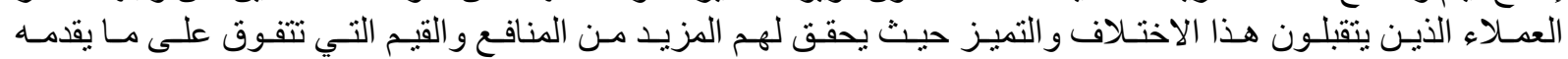

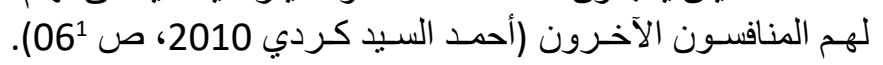

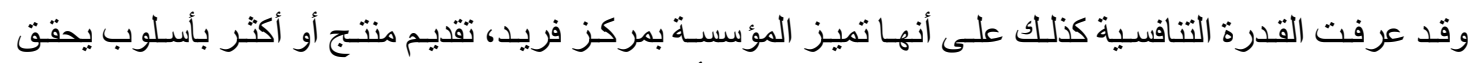

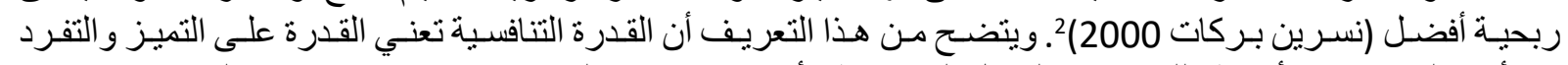

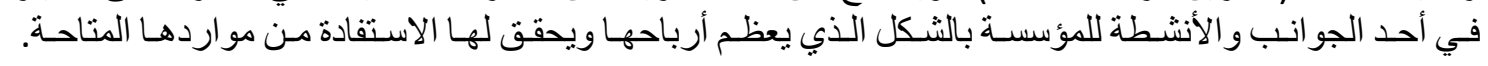

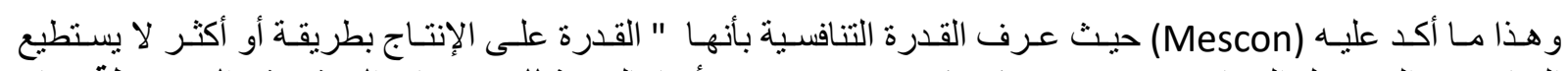

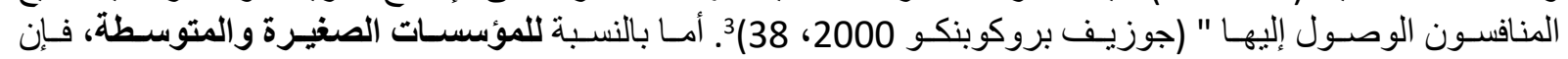

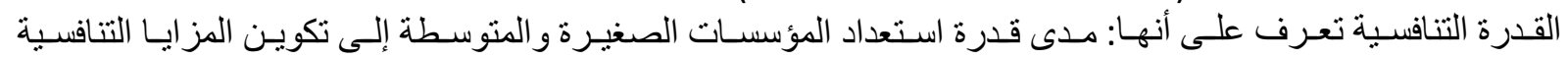

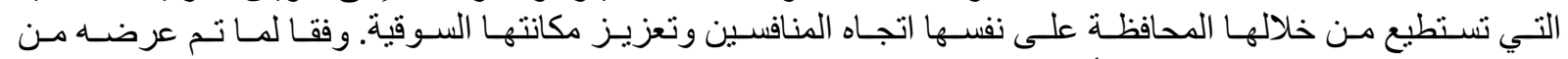

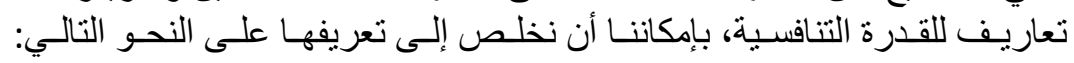

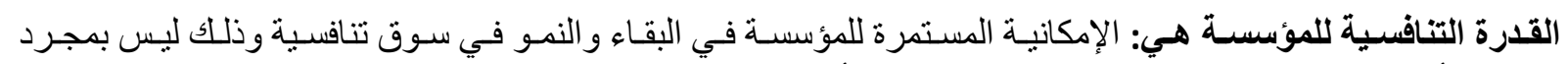

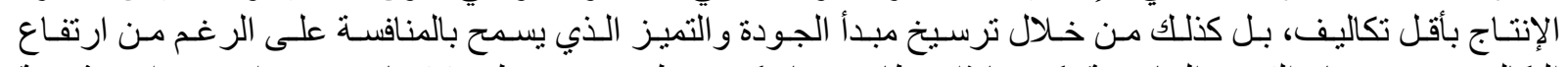

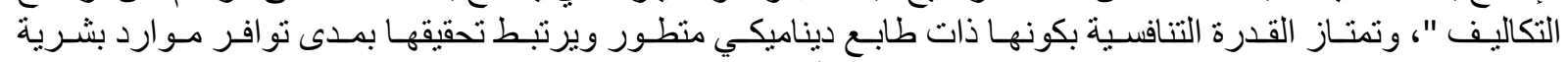

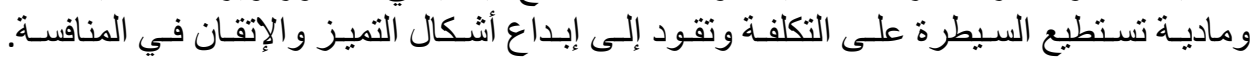

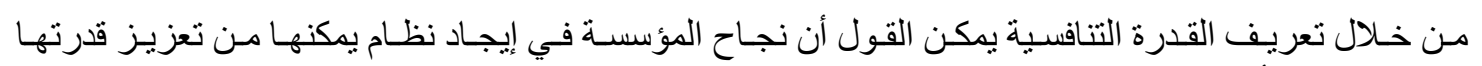

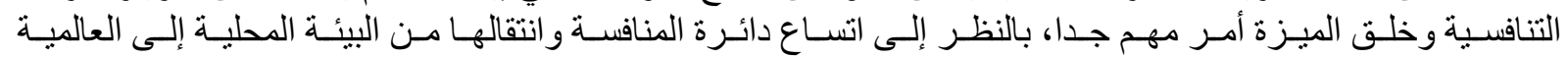

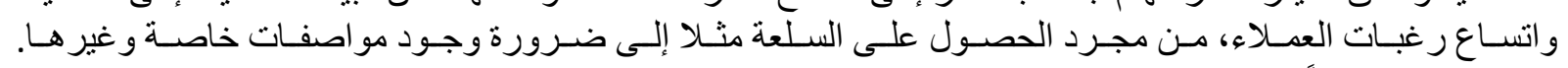

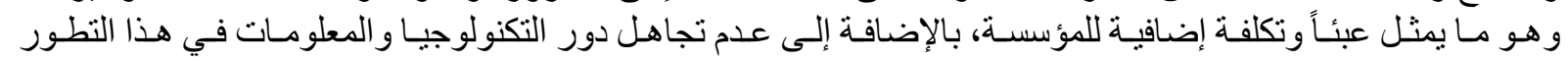
والتغيـر المسـتمر. 


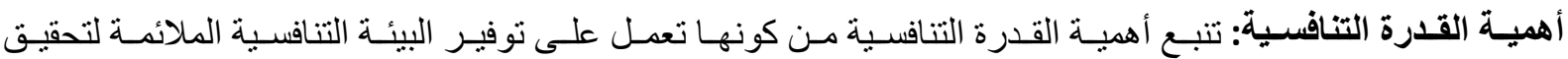

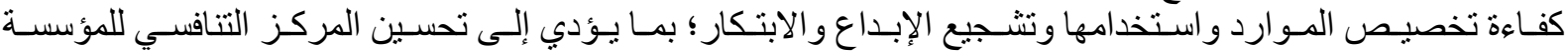

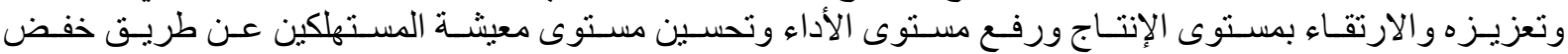

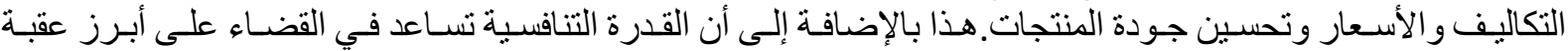

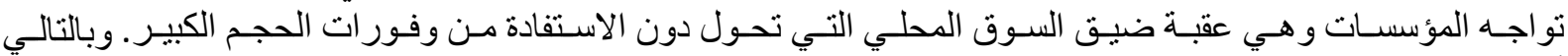

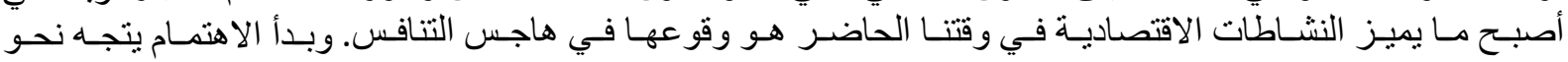

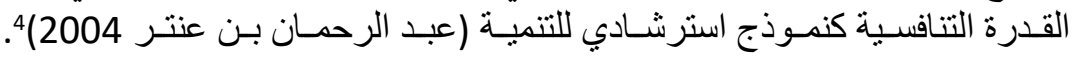

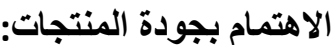

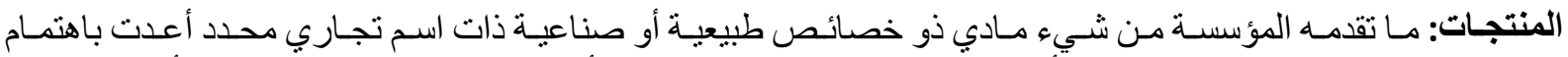

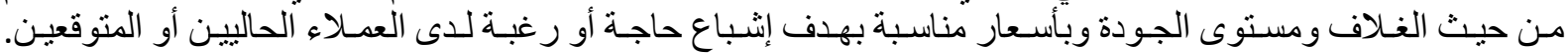

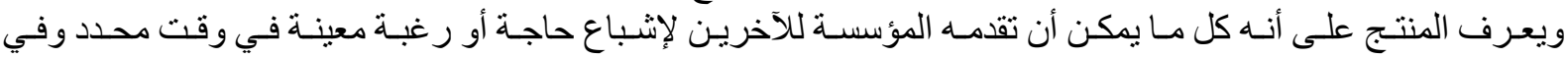

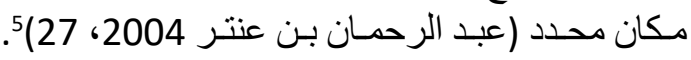

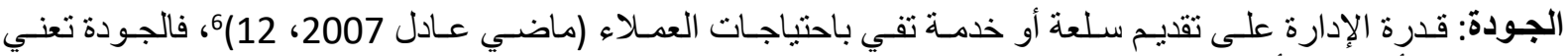

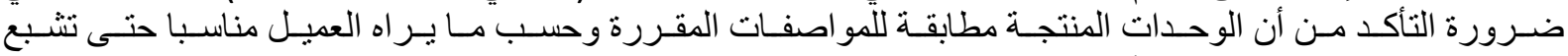

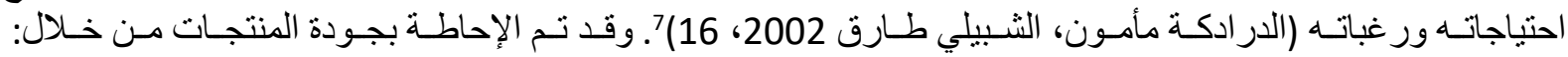

ـ أثر جودة المنتجات على تعزيز القدرة التنافسية للمؤسسات الصغيرة والمتوسطة؛

ـ مدى امتلاك المؤسسات الصغيرة و المتوسطة الجز ائرية لعنصر جودة المنتوج.

التطور التكنولوجي: هو عمليـة التجديد و التحديث للتقنيـات و الآليات التي تستخدمها المؤسسـة في أداء مهامها ونشـاطاتها

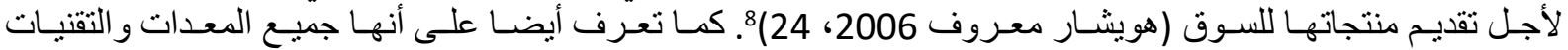

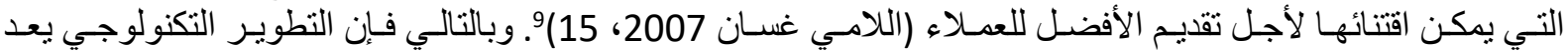

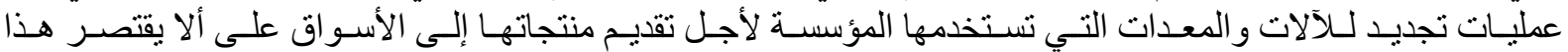

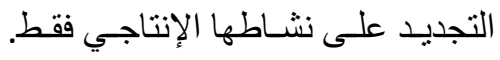

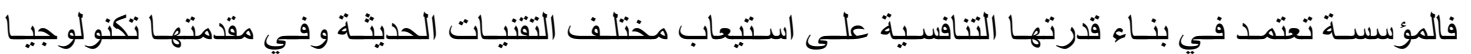

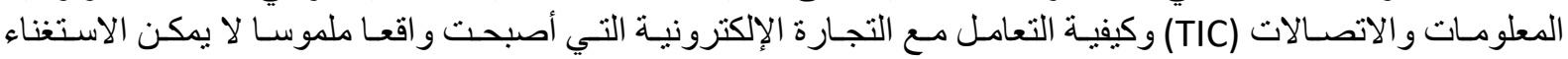

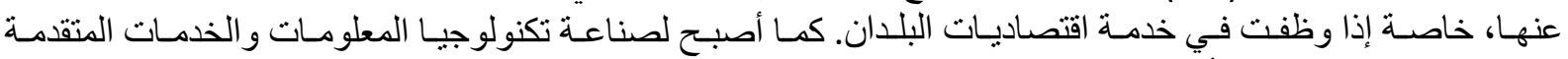

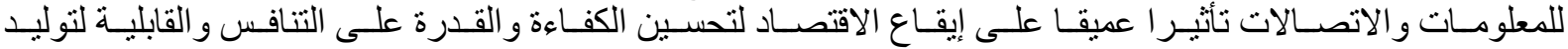

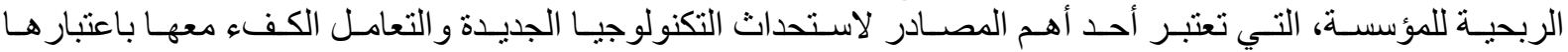

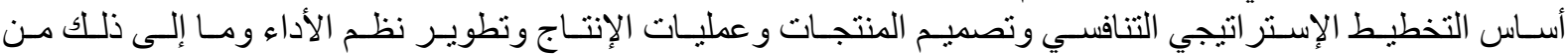

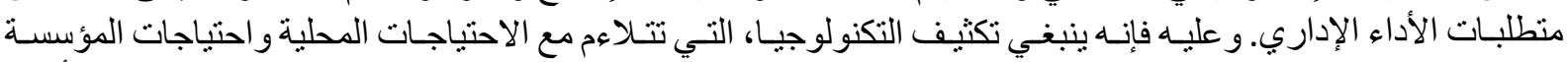

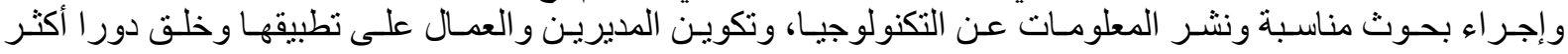

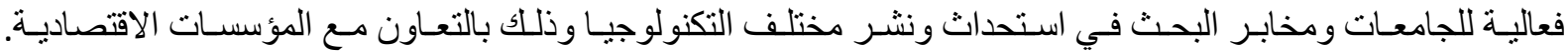

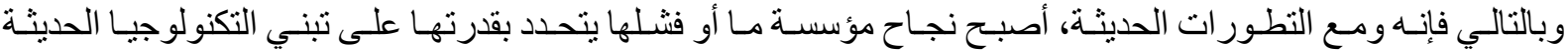

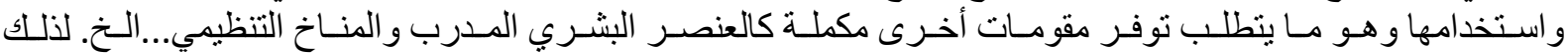

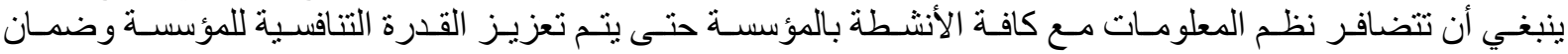

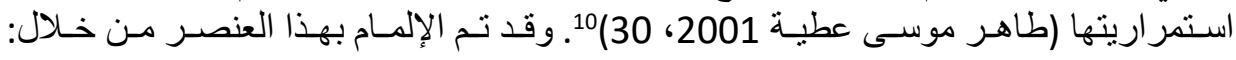

ـ أثر التطور التكنولوجي على تعزيز القدرة التتافسية للمؤسسات الصغيرة والمتوسطة؛

ـ مدى اهتمام المؤسسات الصغيرة و المنوسطة الجزائرية بعنصر التطور التكنولوجي.

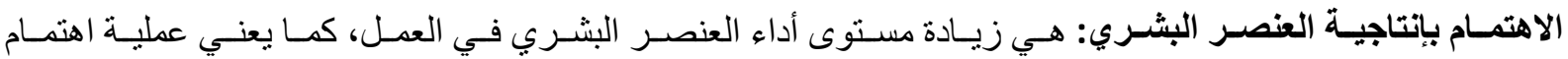

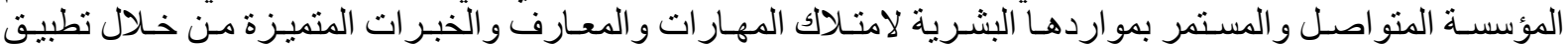

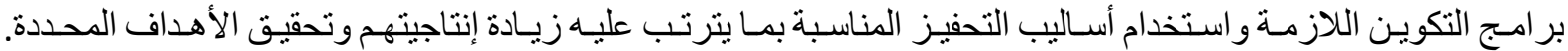

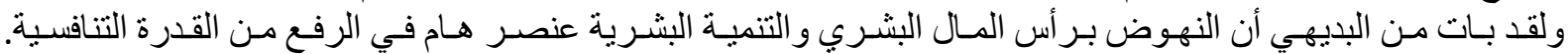

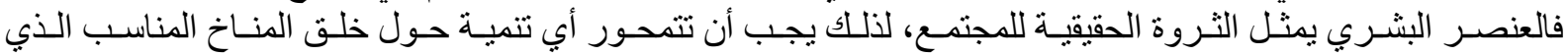




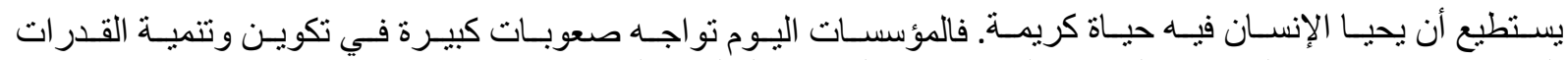

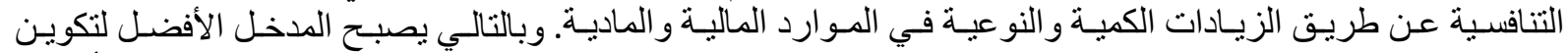

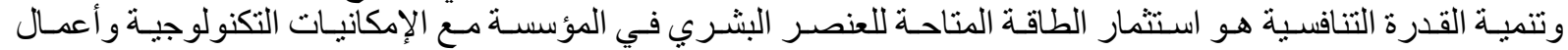

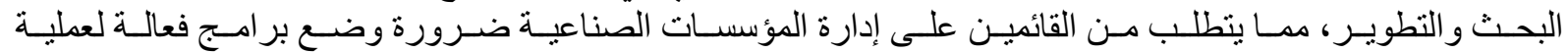

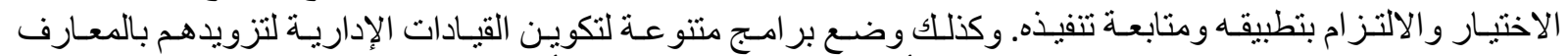

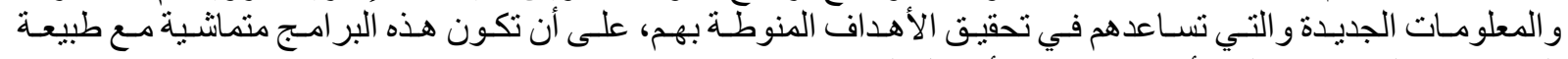

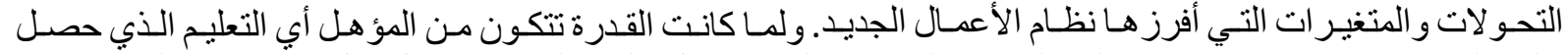

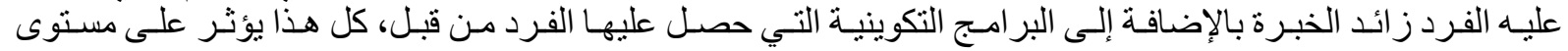

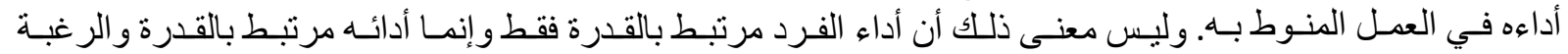

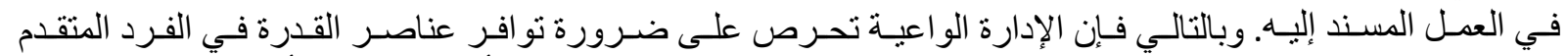

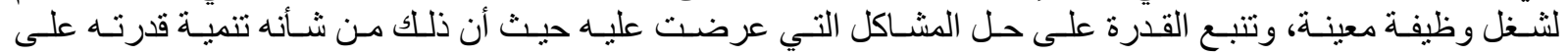

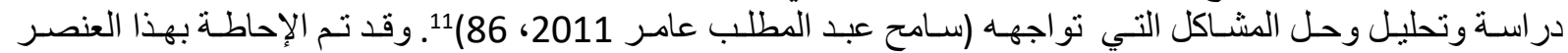

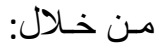

ـ أثر الاهتمام بإنتاجية العنصر البشري على تعزيز القدرة التنافسية للمؤسسات الصغيرة والمتوسطة؛ ـ مدى اهتمام المؤسسات الصغيرة والمتوسطة الجزائرية بتطوير إنتاجية العنصر البشري.

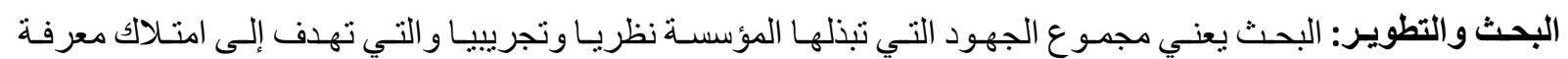

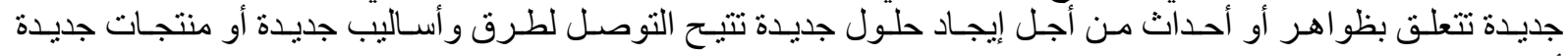

أو كلاهما

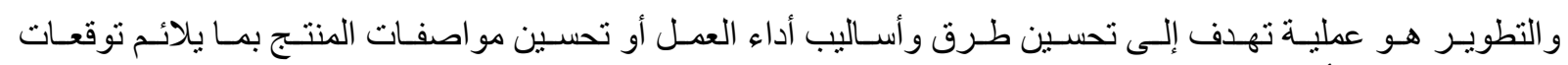

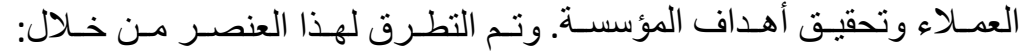
ـ أثر البحث و التطوير على تعزيز القدرة التنافسية للمؤسسات الصغيرة والمتوسطة؛ ـ مدى اعتماد المؤسسات الصغيرة والمنوسطة الجزائرية على عنصري البحث و التطوير.

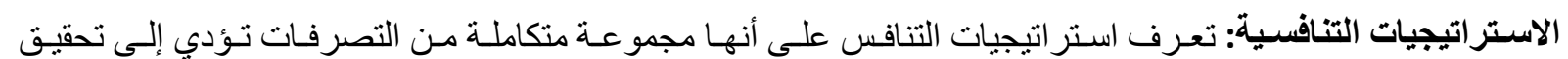

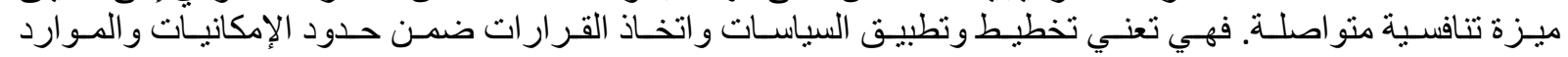

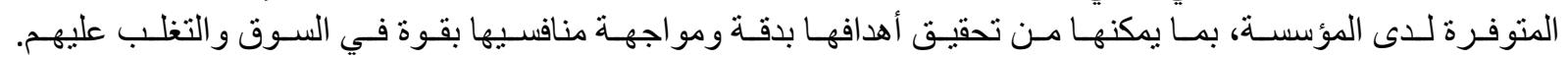

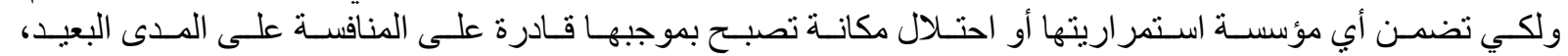

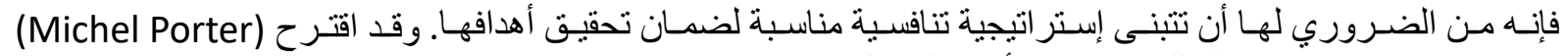

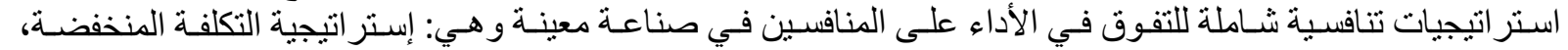

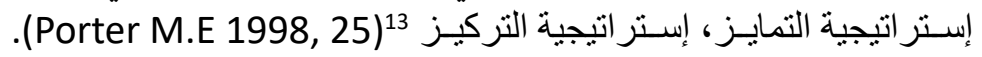

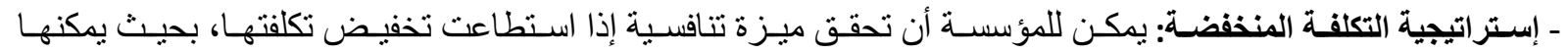

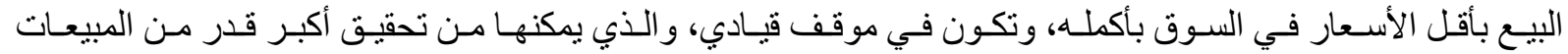

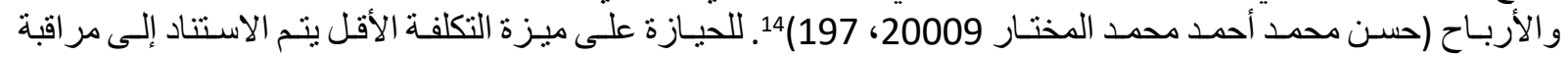

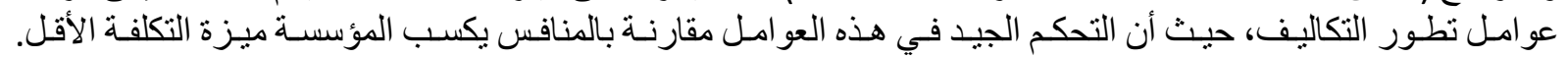

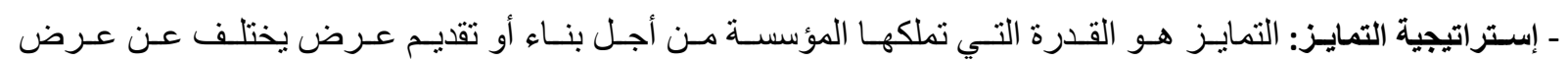

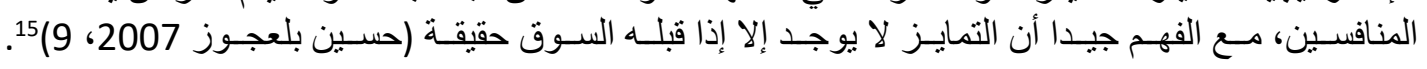

وتتحقق هذه الإستر اتيجية من خلال مجمو عة من المداخل تتمثل في (حسن محمد أحمد محمد المختار 2009، -198 $:{ }^{16}(199$

خلق مز ايا فريدة في أداء المنتج عن المنتجات المنافسة؛ 
تخفيض درجة المخاطر و التكلفة التي يتحملها المستهلك عند شر اء السلعة؛

جعل عملية الصيانة أسهل و أقل تكرار ا؛

مرونة المنتج لتلبية حاجات المستهلك.

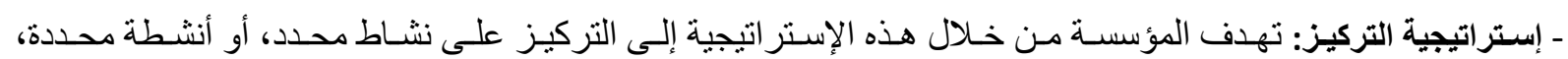

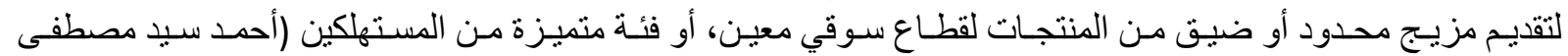

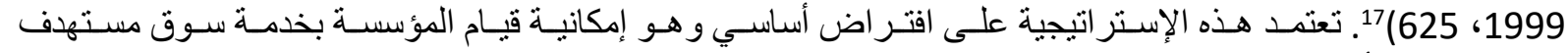

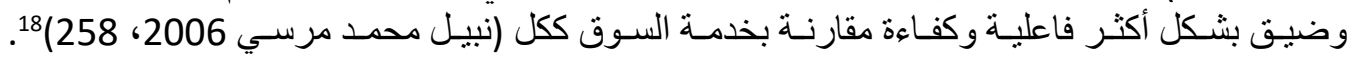
وتأخذ هذه الإستر اتيجية ثلاثة أثكال هي (يحضية سملالي 2003، 29-28) ـ تنميـة السـوق: تتـم تتميـة وتوسـيع سـوق منتجـات المؤسسـة مـن خـلال الحصـول على أكبر حصـة في السـوق الحالي،

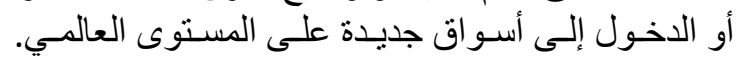

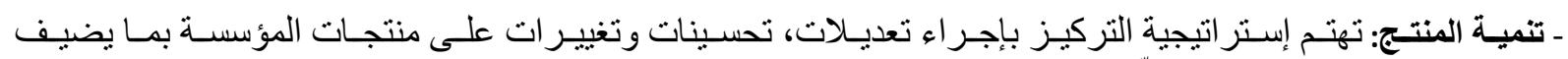

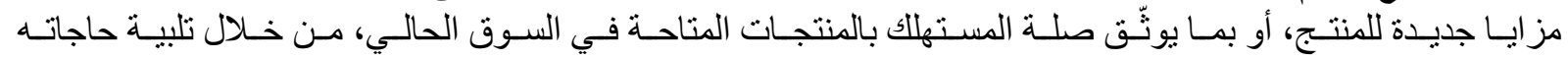
ورغباتـهـ رغـم تنو عهـا وتجددهـا.

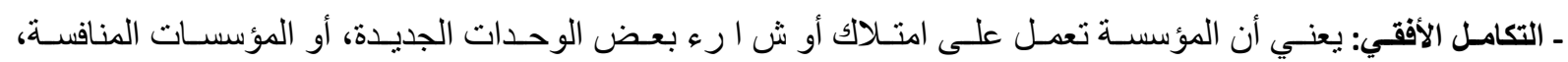

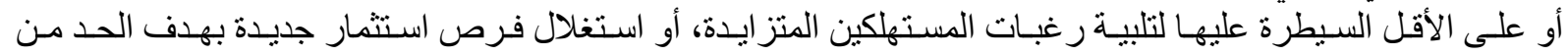

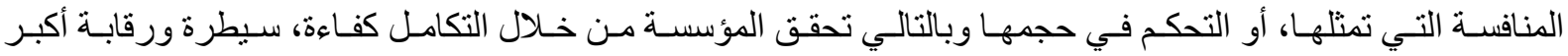
على السـوق.

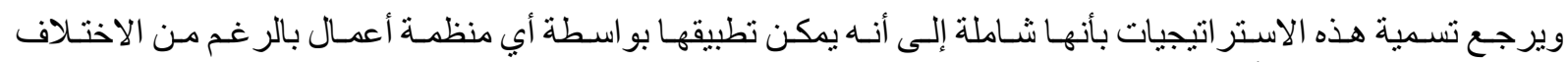

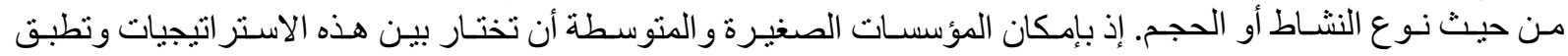

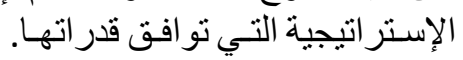

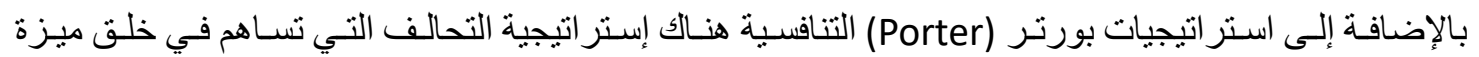

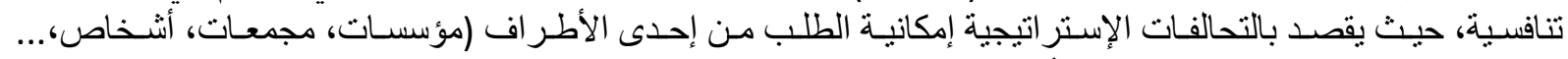

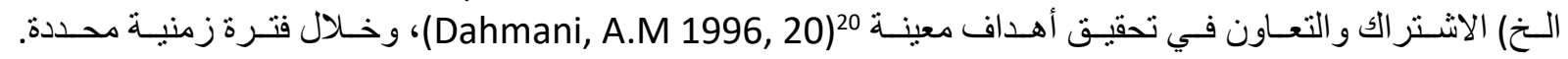

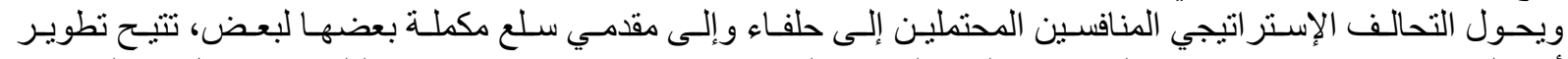

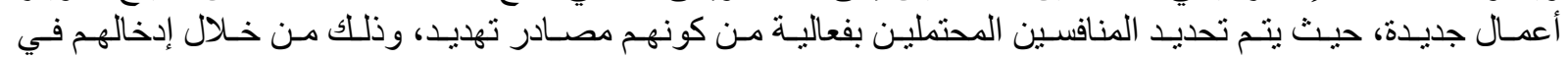

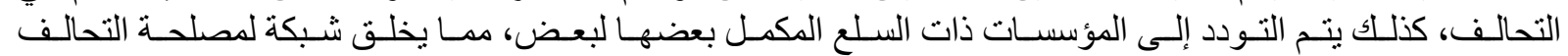

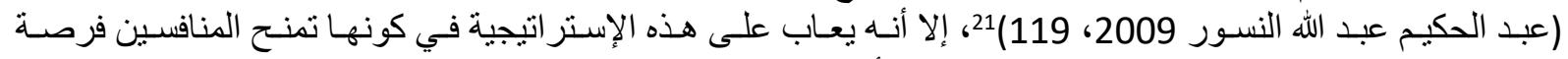

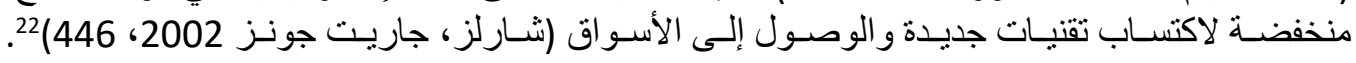

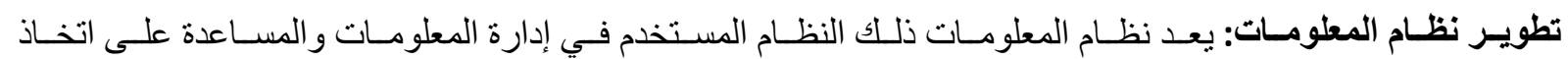

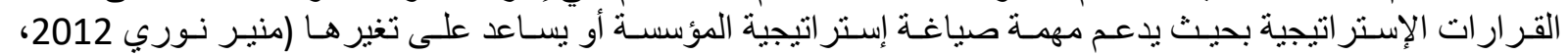

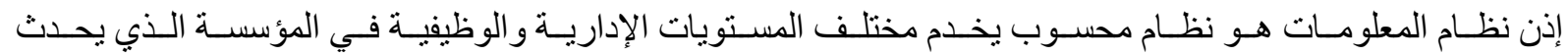

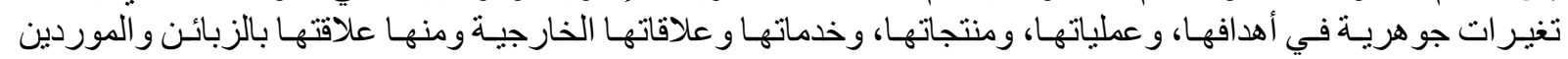

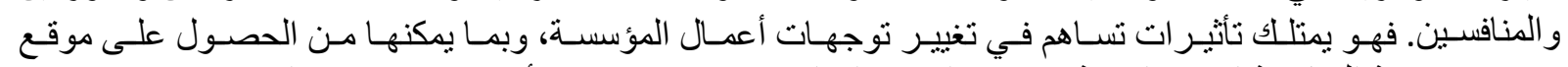

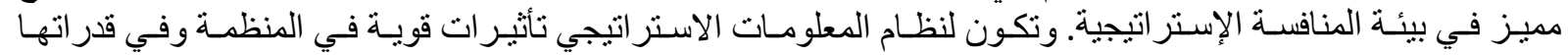

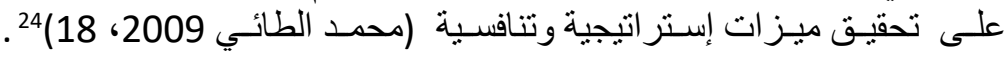

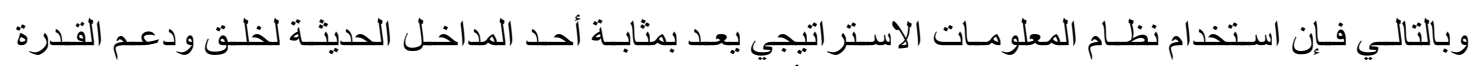

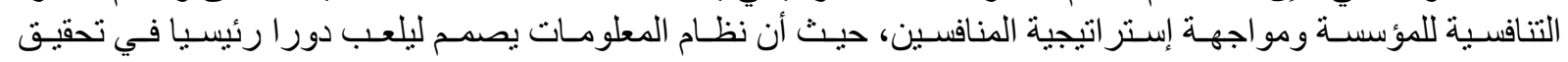

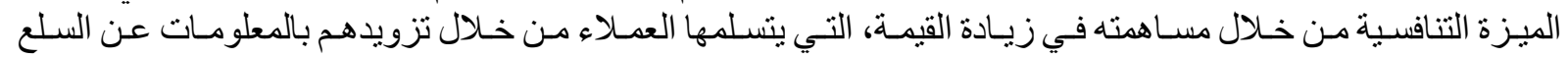

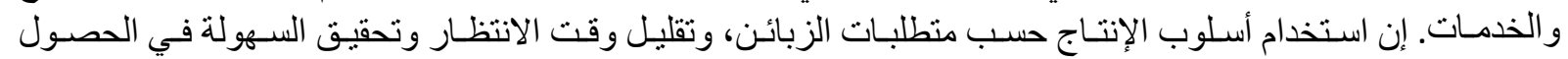


شريف ، محي الدين

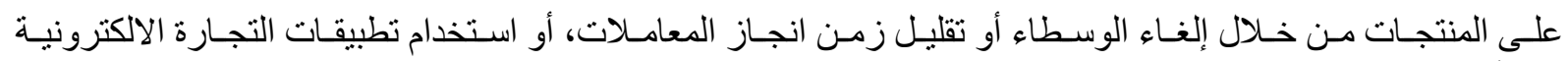
هـي أفضـل منـال على ذلـ ذلك.

الار اسات السابقة:

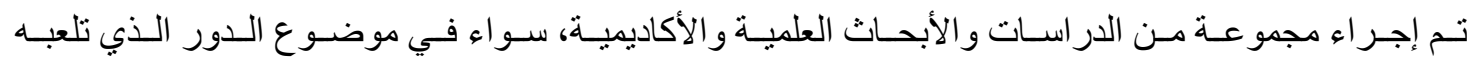

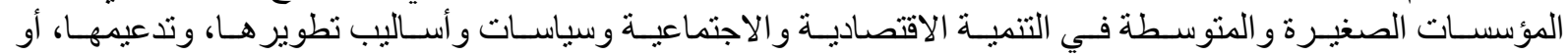

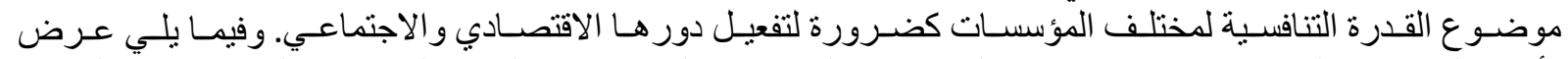

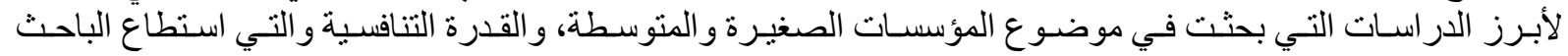
الوصسول إلبهــا:

ـ در اسـة مصطفى بو عقل (2019) موسـومة بـــ " تحليـل القـارة التنافسية للمؤسسـات الصغيـرة والمتوسط الجزائريـة

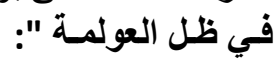

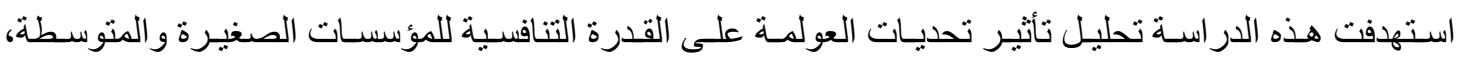

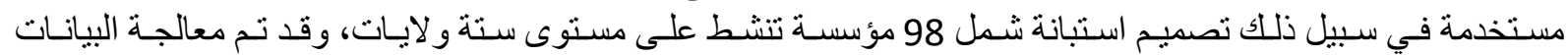

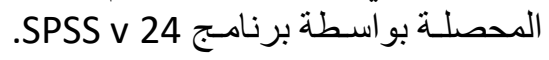

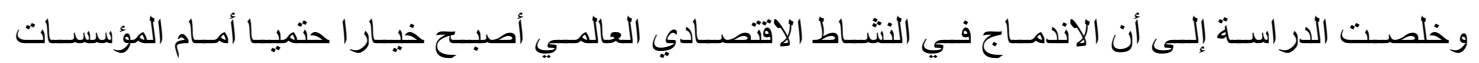

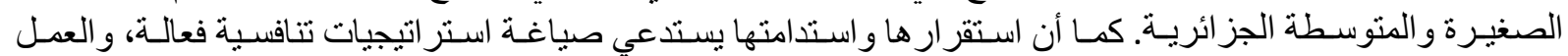

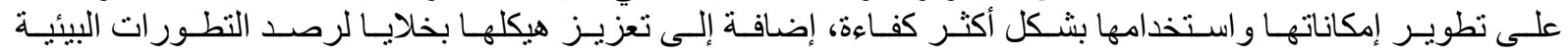

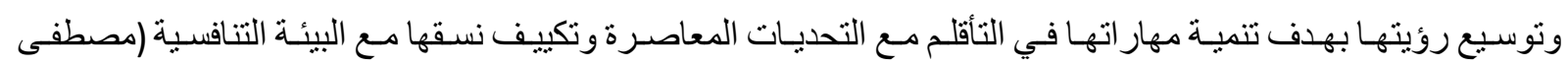

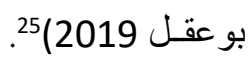

ـ در اسـة فـارس طـارق (2018) تحــت عنـوان "دور ومكانـة المؤسســات الصغيـرة والمتوسـة وسـبل ترقيـة قدرتهـا

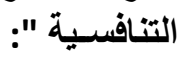

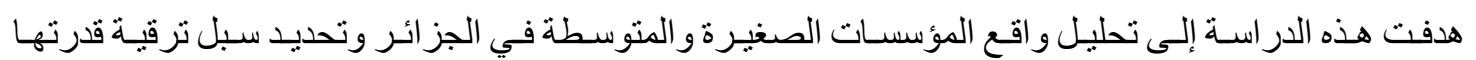

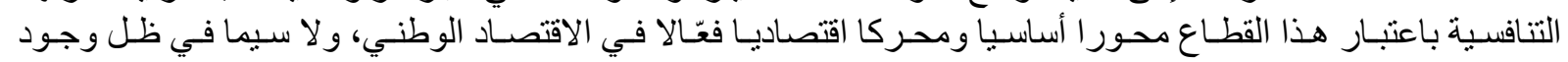

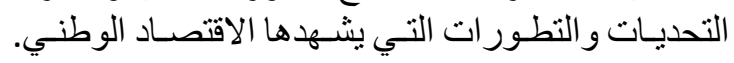

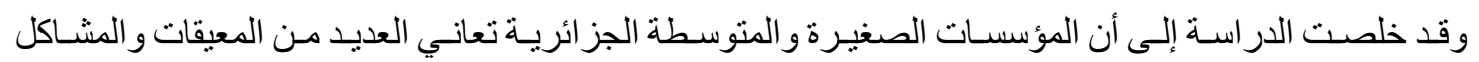

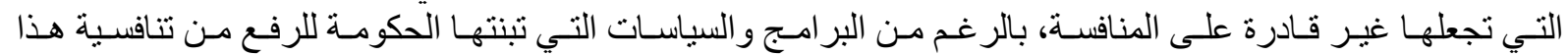

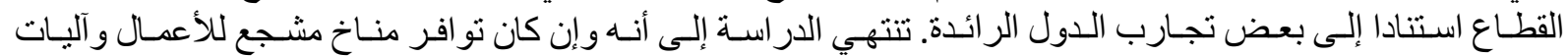

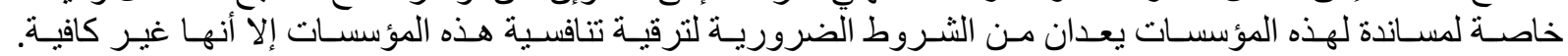

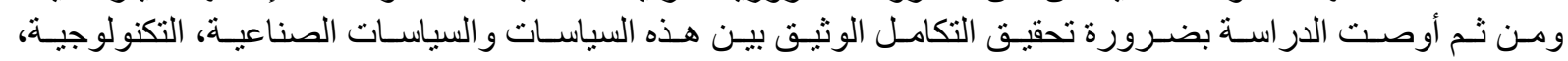

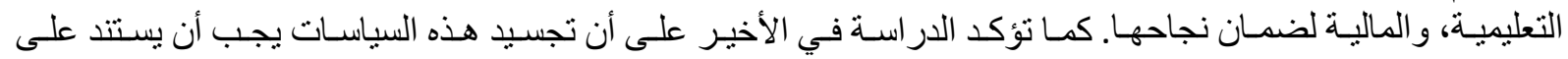

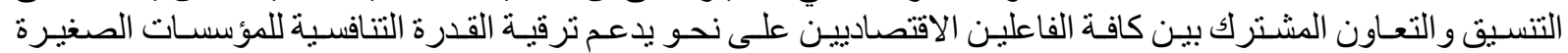

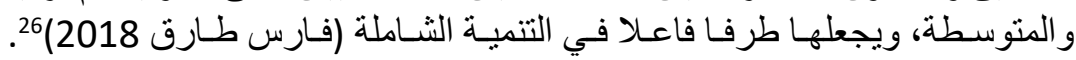

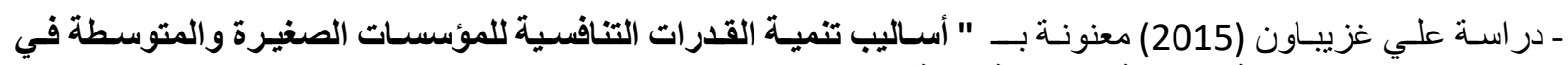

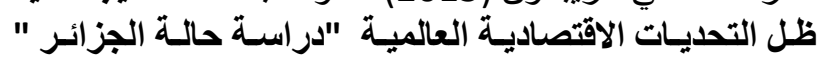

هدفت هذه الدر اسـة إلى تحليـل العو امـل المسـاهمة في تنافسية المؤسسـات الصغيـرة و المتوسـة وفي وفي تعزيز

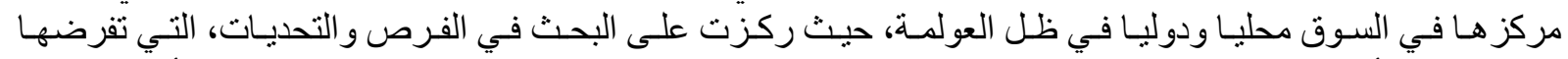

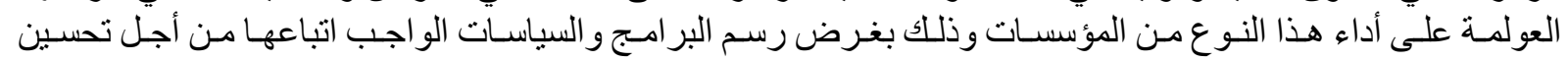

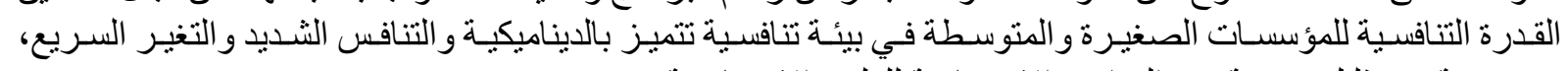

مستخدمة في ذلك حزمسة مـن البر امسج الإحصائيـة للعلكوم الاجتماعيـة (SPSS 20) 


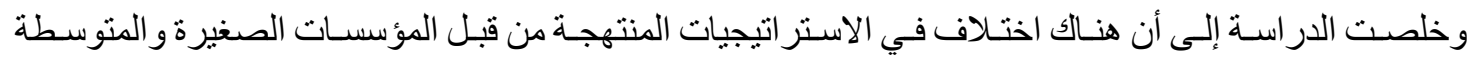

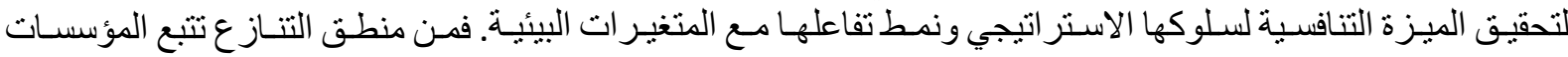

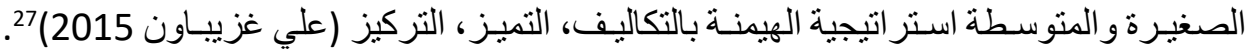

ـ در اسة خياري زهية (2010) المعنونة بـ "تحسين الإنتاجية كمدخل لتعزيز القدرة التنافسية "

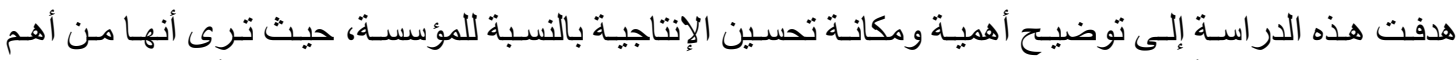

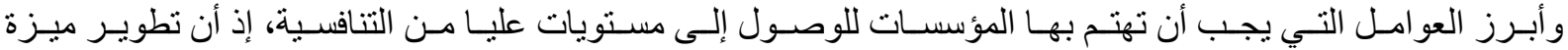

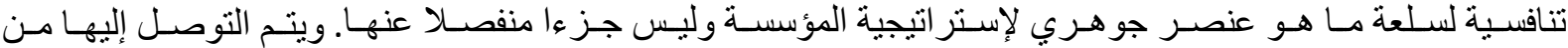

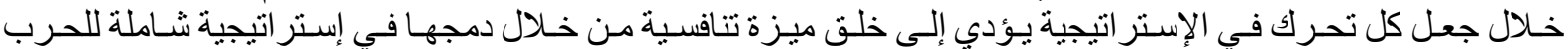
التسـويقية في مول اقع ديناميكيـة للصنئاعـة.

وقد توصلت هذه الدر اسـة إلـى وجـود علاقـة تكامليـة بيـن مفهومسي الإنتاجيـة و التنافسية، وأن الإنتاجيـة تعتبـر

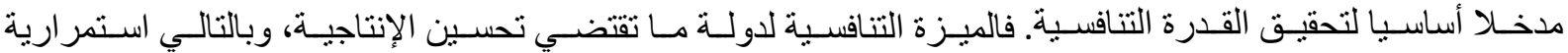

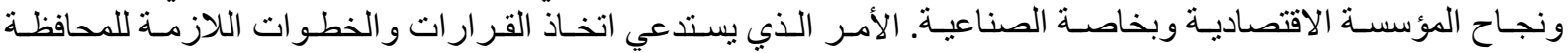

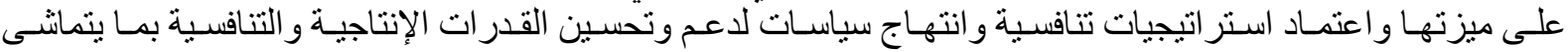

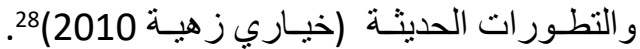

- دراسة فرحات غول (2006) بعنوان "مؤشرات تنافسيـة المؤسسـات الاقتصاديـة في ظل العولمـة الاقتصاديـة (حالـة

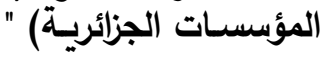

استـهوفت هذه الدر اسـة البحـث في مؤشـر ات التنافسية بالنسبة للمؤسســات الاقتصاديـة وبخاصـة الجز ائريـة منهـا

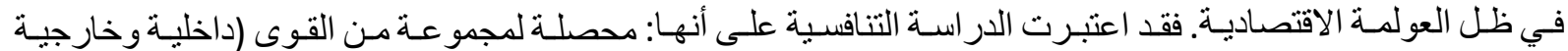

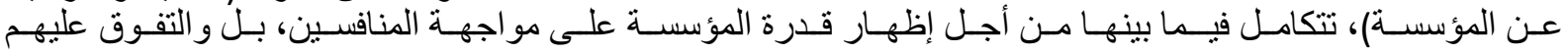

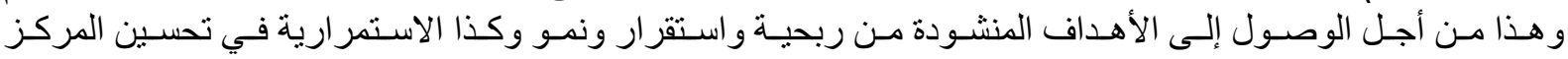

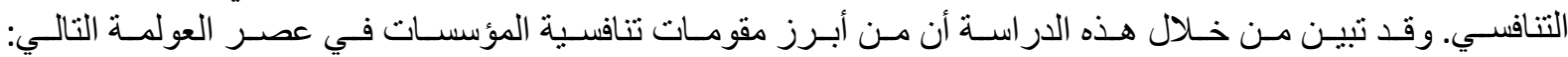

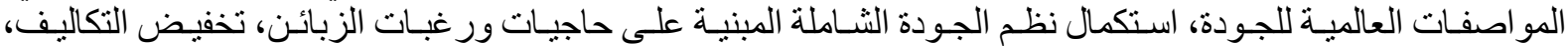

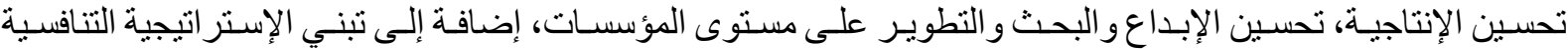
المتعسارف عليهـا وتطوير هـا.

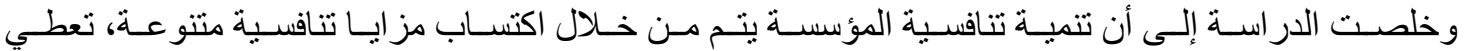

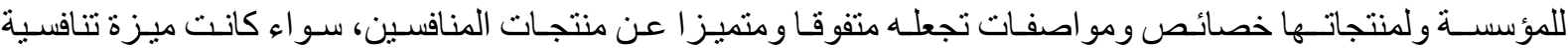

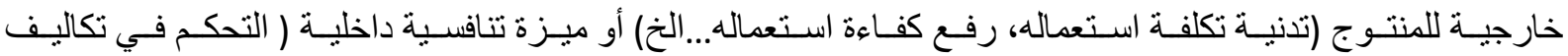

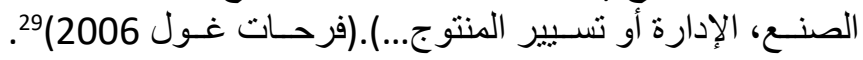

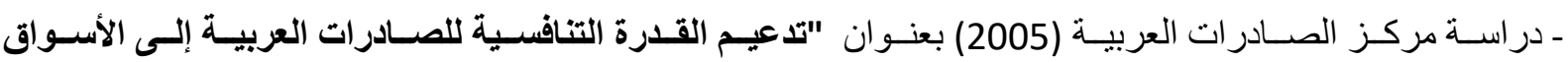

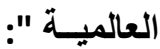

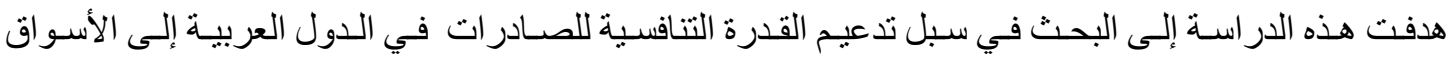

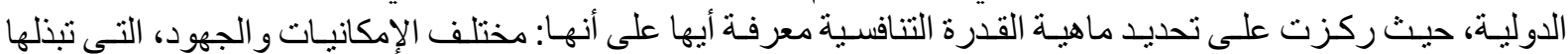

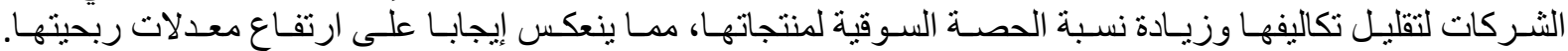

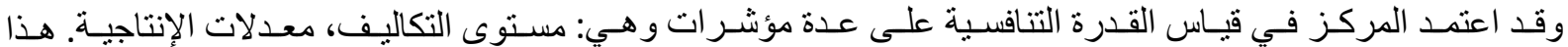

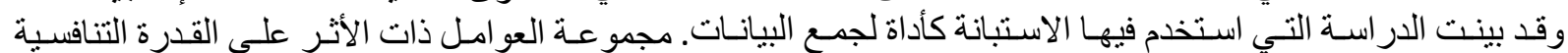

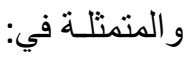

أ. قدرة المنشآت على إجر اء در اسات للأسواق الخارجية المستهدفة يُكسبها تعزيز ا لقدر اتها التنافسية؛ ب. تعزيز المنشآت الصناعية لقدر اتها التنافسية يأتي من خلال الاهتمام الجاد بدر اسة وتحليل الأسواق الخارجية؛

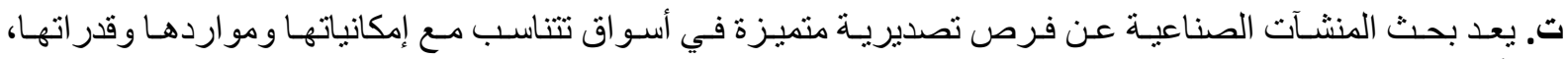

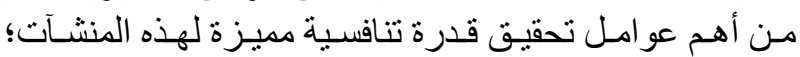

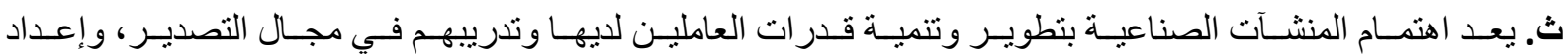


شريف ، محي الدين

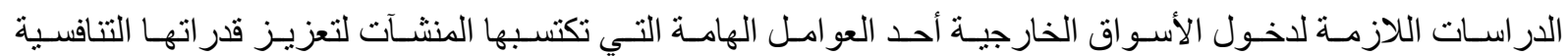

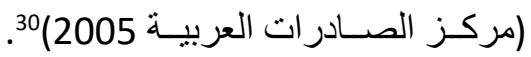

- در اسة عبد الرحمان بن عنتر (2004) بعنوان " تحسين الإنتاجية وتدعيم القدرة التنافسية للمنتجات الصناعية "

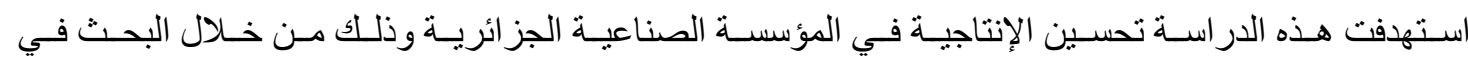

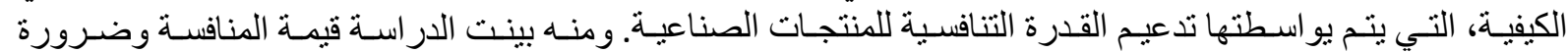

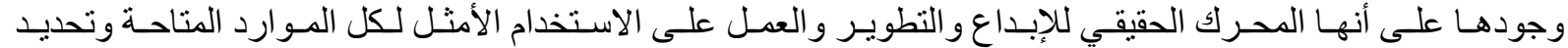

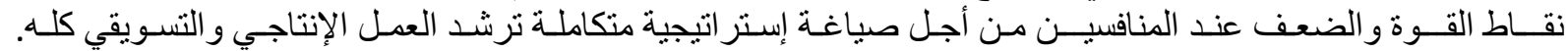

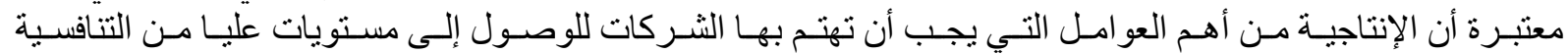

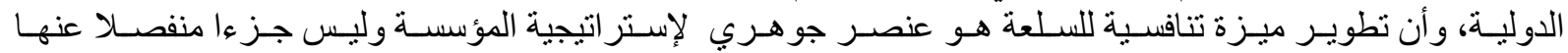

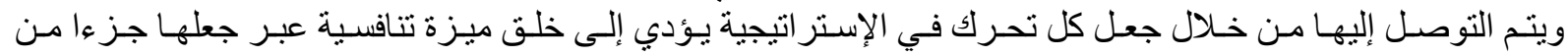

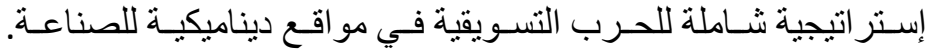

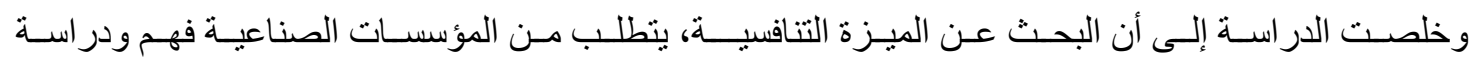

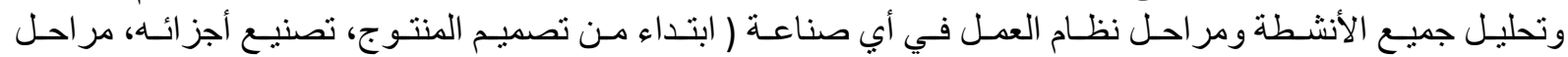

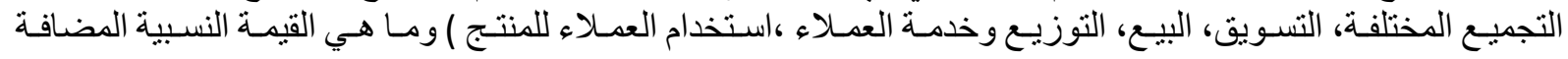

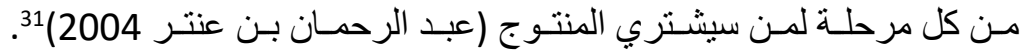

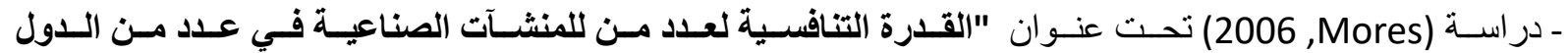
الصناعيـة" الصة

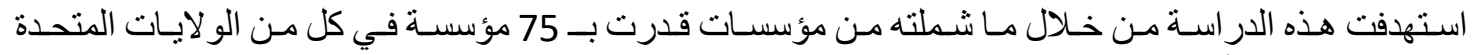

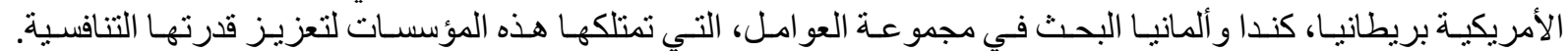

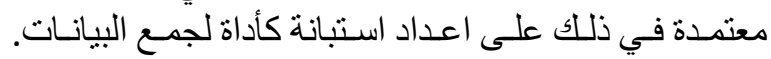

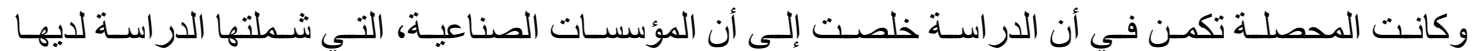

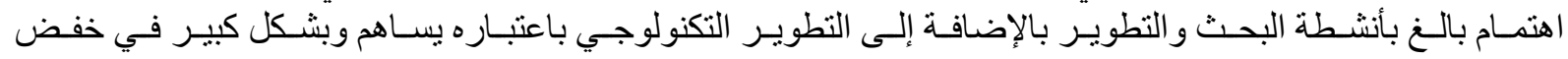

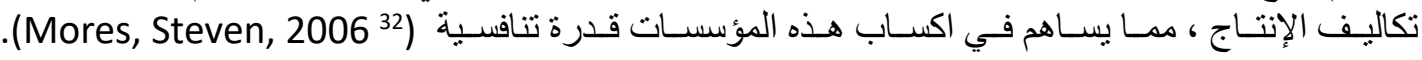

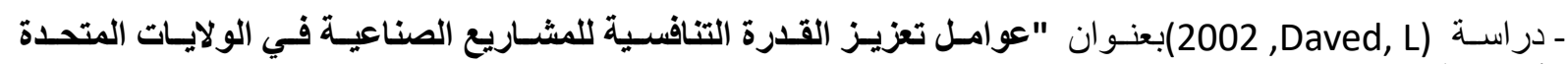

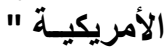

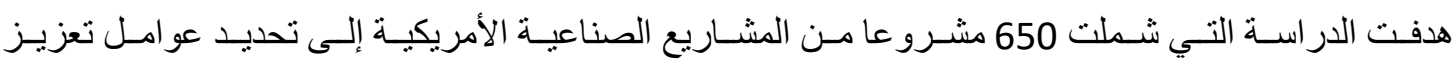

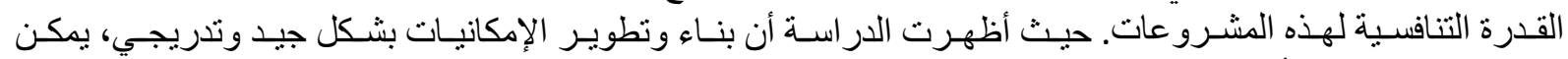

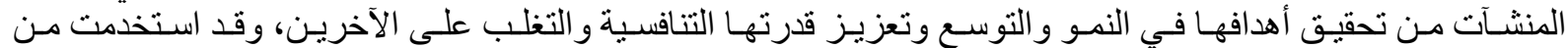

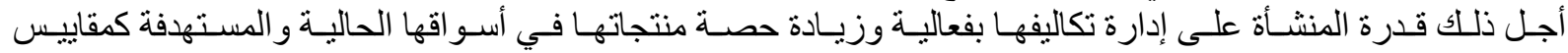

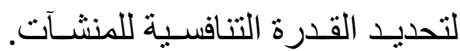

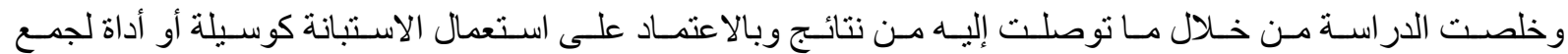

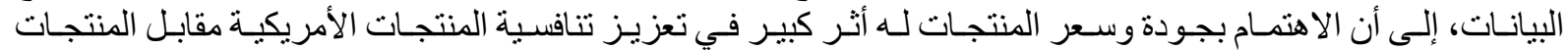

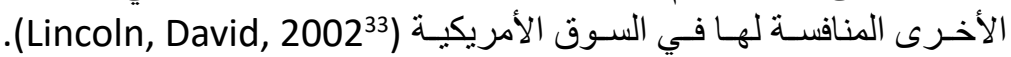
- در اسة (Labich, 1996) بعنوان "تعزيز القدرة التنافسية لمنشآت القطاع الخاص "

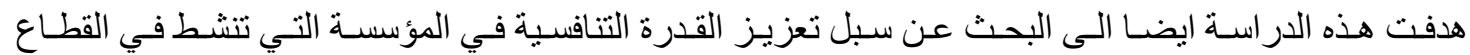

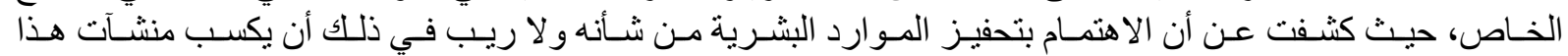

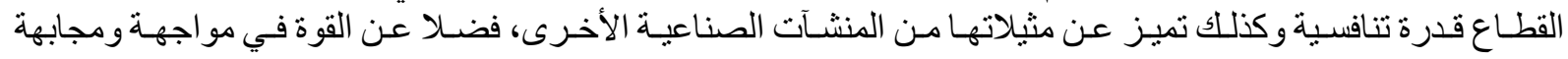

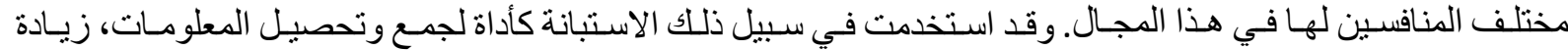

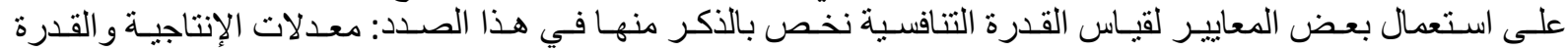
على خفض التكاليف (Labich, K, 199634).

ـ در اسـة (Cadden \& Larid, 1995) المعنونـة بـ "عوامـل تعزيـز القدرة التنافسية لمنشـآت القطـاع الخـاص الصناعية في كندا " دراست 


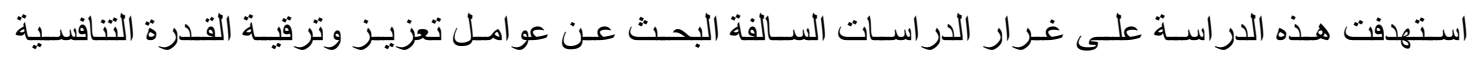

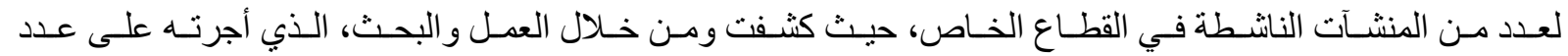

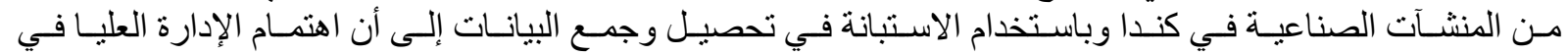

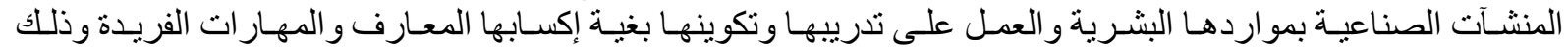

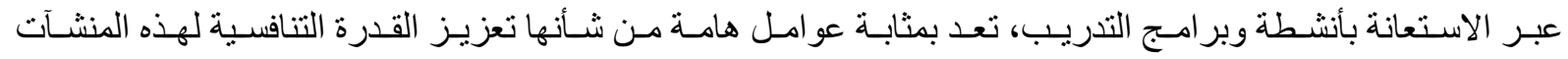

(.Cadden, M, \& Larid,B, ${ }^{35}$ 1995)

- دراسة (1994 Fireman) بعنوان "عوامل القدرة التنافسية لمنثآت القطاع الخاص "

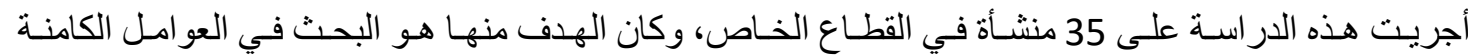

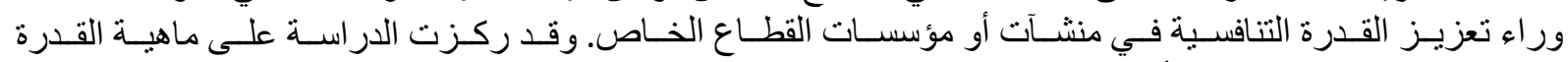

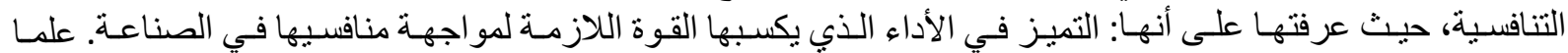

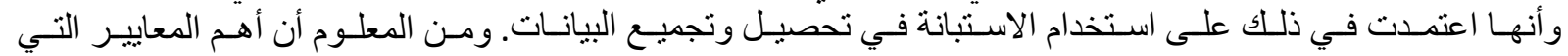

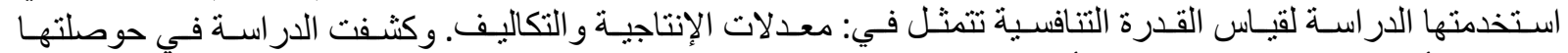

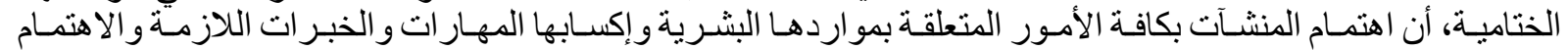

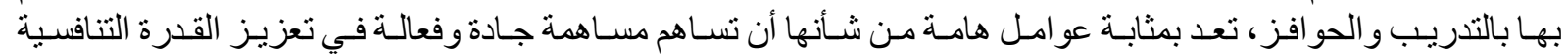

للمنشـأة ( Fireman, J,1994 ).

- در اسة (1980 Abell) بعنوان "(لقدرة التنافسية للمنشآت الصناعية أ

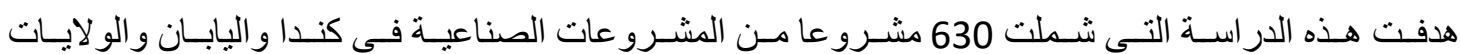

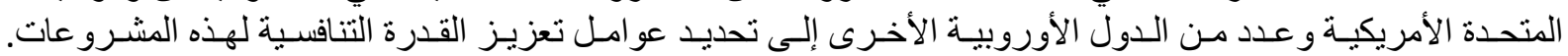

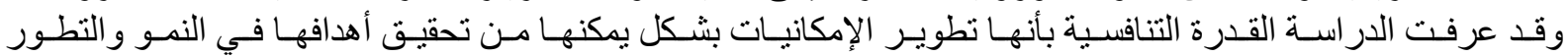

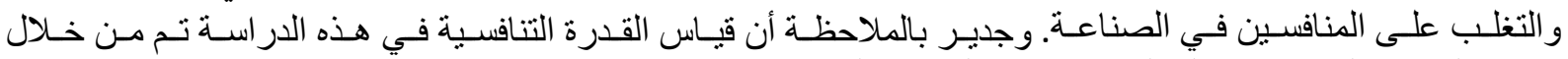

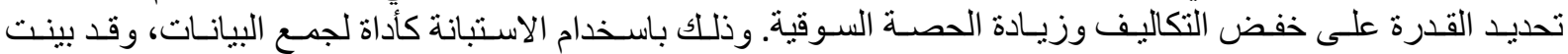

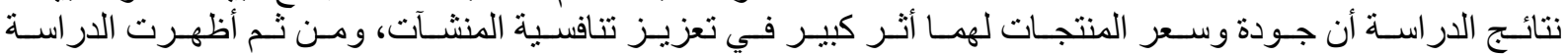

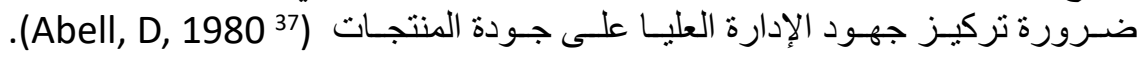

\section{منهجية الار اسة:}

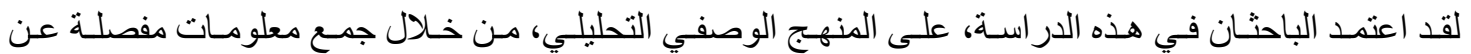

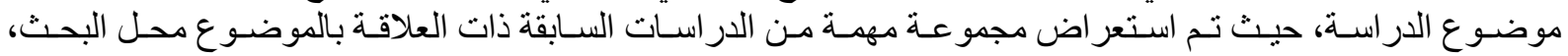

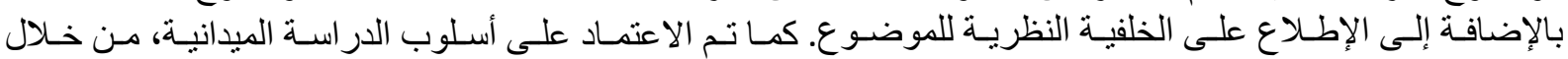

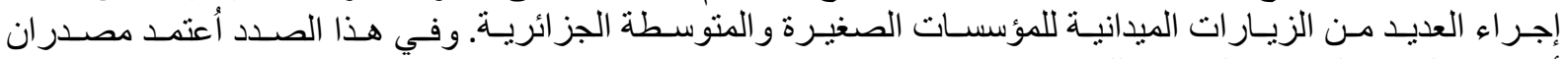

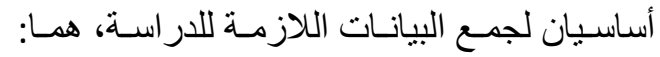

أو لا: المصادر الثانوية: من خلال اعتماد الكتب والأبحاث و الدراسات السابقة التي تتعلق بموضوع الدر اسة.

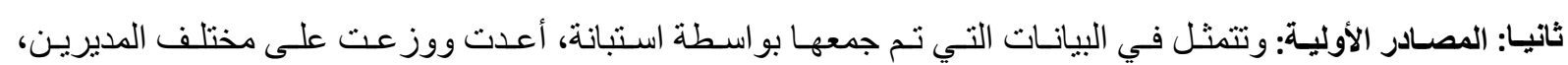

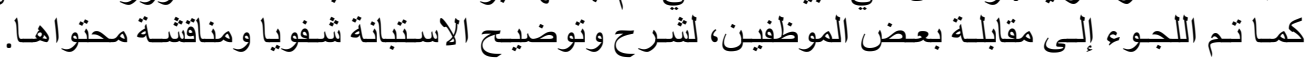

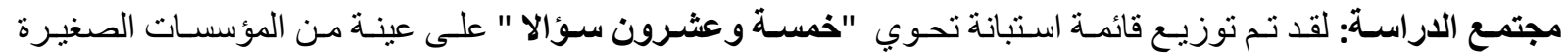

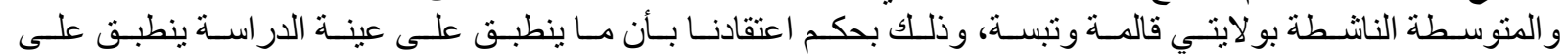

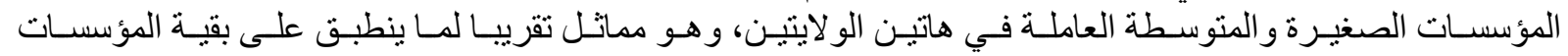

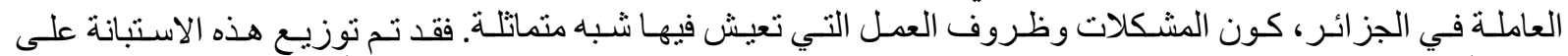

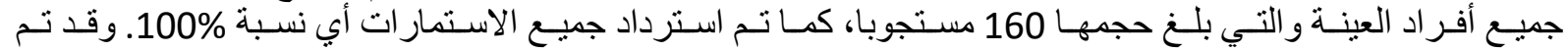

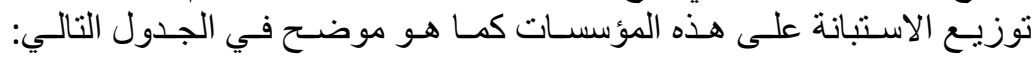


شريف، محي الدين

جدول (1): عدد الاستبانات العائدة بالنسبة للمؤسسات الصغيرة والمتوسطة العاملة بولاية قالمة

\begin{tabular}{|c|c|c|c|c|c|}
\hline \multicolumn{3}{|c|}{ المؤسسات الصغيرة و المتوسطة العاملة بولاية تبسة } & \multicolumn{3}{|c|}{ المؤسسات الصغيرة والمتوسطة العاملة بولاية قالمة } \\
\hline الاستبانات & 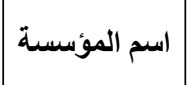 & الرقم & المتباتات & 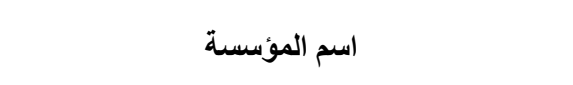 & 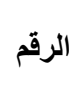 \\
\hline 6 & |للمشيال & 01 & 5 & شركة فنجال للمشروبات الغازية & 01 \\
\hline 4 & |البيضاءة & 02 & 8 & 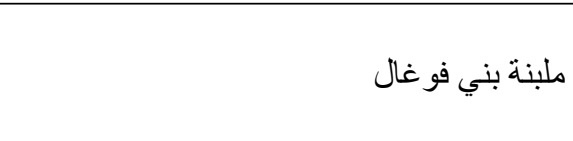 & 02 \\
\hline 6 & ملبنة ميلك & 03 & 4 & شركة التضامن الإخوة بوكبو & 03 \\
\hline 4 & | لمشركة جودي & 04 & 8 & مطحنة مجمو عة عبيدي & 04 \\
\hline 4 & - الصفاء & 05 & 9 & مطاحن الصافية & 05 \\
\hline 16 & شيركوسة & 06 & 2 & مؤسسة در اجي عبد العالي لصناعة المكنسات & 06 \\
\hline 10 & - الحياه & 07 & 2 & مؤسسة الريان لتوضيب وتغليف المواد الغذائية & 07 \\
\hline 7 & |للششركة مروى | & 08 & 4 & شركة البسباسة للمياه & 08 \\
\hline 13 & | تيفركت للمياه & 09 & 2 & و كالة الماسة تور & 09 \\
\hline 5 & 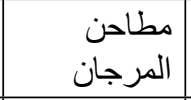 & 10 & 12 & شركة الجنوب لحفظ المو اد الغذائية & 10 \\
\hline 3 & مؤسسة & 11 & 9 & ملبنة كافاك & 11 \\
\hline 2 & | يوكوسلة & 12 & 4 & شركة لوزا منال لعصر الزيتون & 12 \\
\hline \multirow{3}{*}{80} & \multirow{3}{*}{\multicolumn{2}{|c|}{ 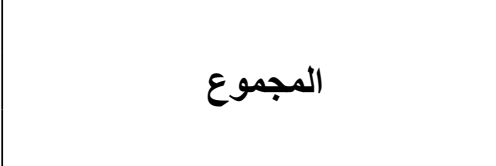 }} & 8 & شركة نفيدسة للاهون & 13 \\
\hline & & & 3 & شركة أبو اب 24 لصناعة الخشب & 14 \\
\hline & & & 80 & 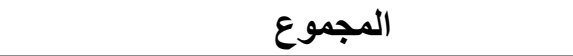 & \\
\hline
\end{tabular}

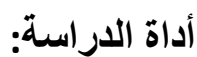

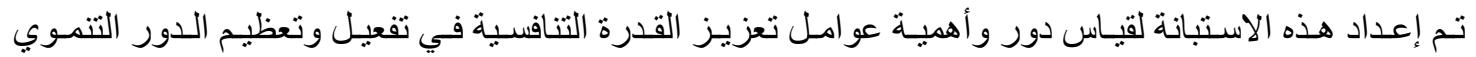

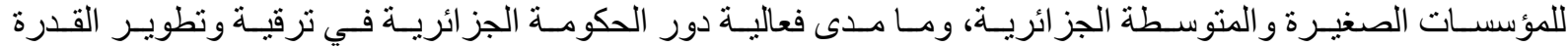
التنافسية لهذه المؤسســات. وقد قسـم هذه الاسـتبانة إلى أربعـة محساور كالآتـي: المحور الأول: عو امل تعزيز القدرة التنافسية للمؤسسات الصغيرة والمنوسطة. المحور الثاني: دور وأهمية تعزيز القدرة التنافسية للمؤسسات الصغيرة والمتوسطة في تفعيل دور ها التتموي. 
المحور الثالث: مدى امتلاك المؤسسات الصغيرة والمتوسطة الجز ائرية (قالمة/تبسة) لعو امل تعزيز القدرة التنافسية.

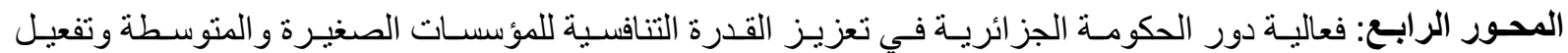
دور هـا التنمـوي. ولقيـاس مـدى استجابة المبحوثيـن لفقرات الاسـتبانة، تـم اسـتخدم مقيـاس ليكارت الخماسـي، كمـا هـو موضـح

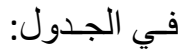

$$
\text { جدول (2): مقياس ليكارت الخماسي }
$$

\begin{tabular}{|c|c|c|c|c|c|}
\hline غير موافق بشدة & غير موافق & لا أدري & موافق & موافق بشدة & التصنيف \\
\hline 5 & 4 & 3 & 2 & 1 & الدرجة \\
\hline
\end{tabular}

المصدر: محمد خير سليم أبو زيد (2010)، التحليل الإحصائي للبيانات باستخدام برمجة SPSS، دار جرير للنشر والتوزيع الأردن، ص ص 416.

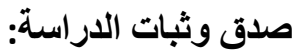

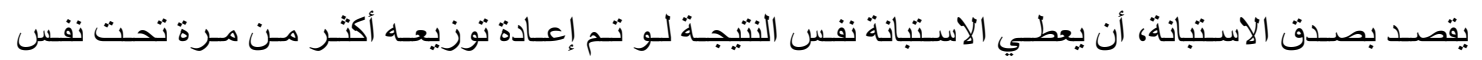

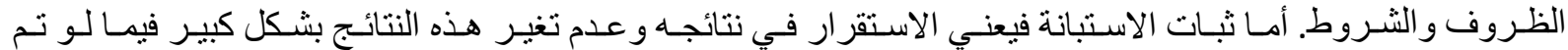

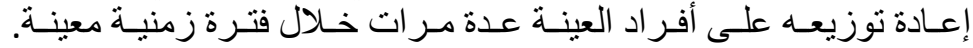

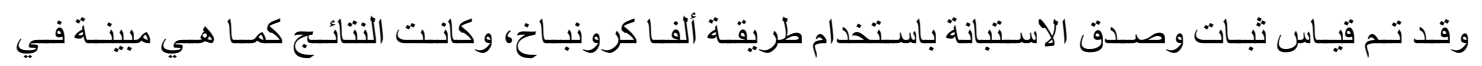

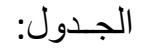
جدول (3): معامل ألفا كرونباخ لقياس ثبات الاستبانة

\begin{tabular}{|c|c|c|c|}
\hline الصدق* & ألفا كرونباخ & عدد الفقرات & \\
\hline 0,88 & 0,787 & 25 & جميع الفقرات \\
\hline
\end{tabular}

SPSS.20 المصدر: من إعداد الباحثبن بالاعتماد على مخرجات

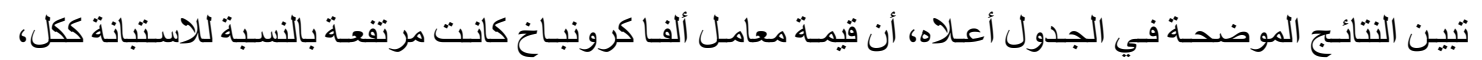

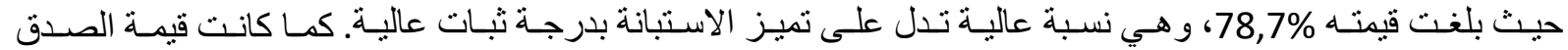
مرتفعـة كذللك، إذ بلغت الأساليب والمعالجة الإحصائية:

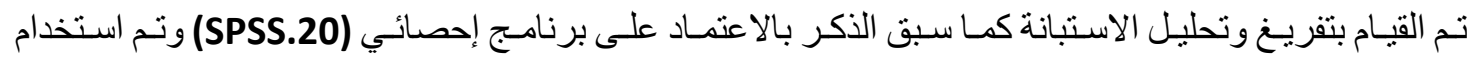

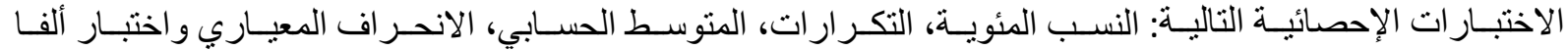

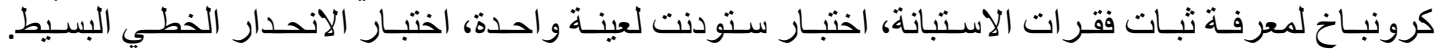

أولا. اختبار الفرضيات

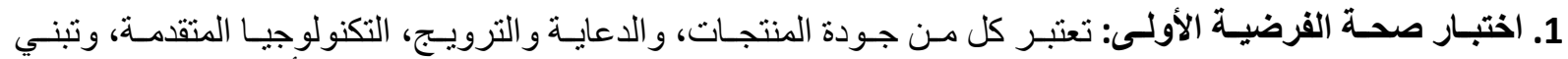

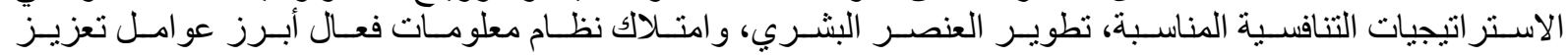

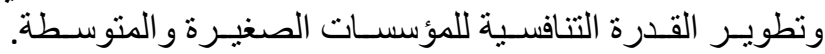
وقد انبثقت عن هذه الفرضية ست فرضيات فر عية، سنعرض اختبار كل و احدة منها ونناقتشها كالآتي: الفرضيـة الفرعيـة الأولى: ليس هنـاك أثثر ذو دلالـة إحصائيـة لجـودة المنتجـات على تعزيـز القدرة التنافسية للمؤسسـات الصغيرة و المتوسـة الفرعة الاوكي 
شريف، محي الدين

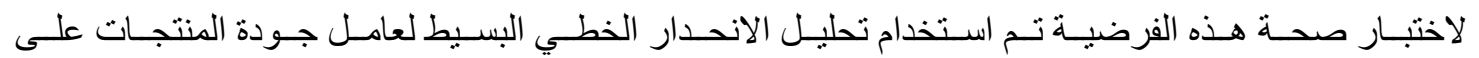

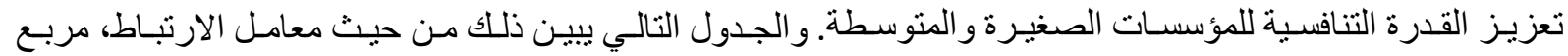

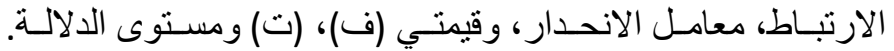

جدول (4): نتائج تعليل الانحدار الخطي البسيط لأثر جودة المنتجات على تعزيز القدرة التنافسية

\begin{tabular}{|c|c|c|c|c|c|c|c|}
\hline نتيجة الفرضية العدمية & مستوى الدلالة & قيمة ت & ق ق قيمة ف & الاتحدار & التحديد Rعلم & الارتباط & \\
\hline & & & & 0,478 & & & قيمة الثابت \\
\hline رفض & 0,000 & 7,500 & 56,246 & 1,247 & 0,263 & 0,512 & جودة المنتجات \\
\hline
\end{tabular}

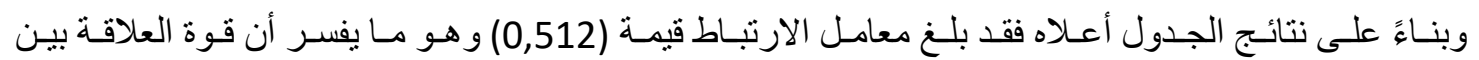

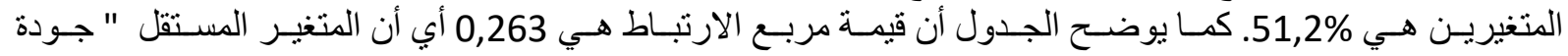

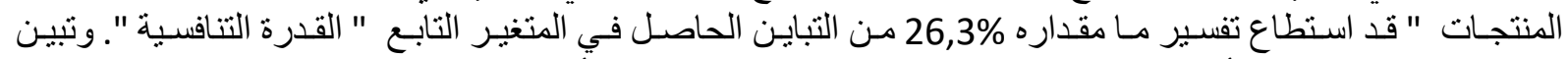

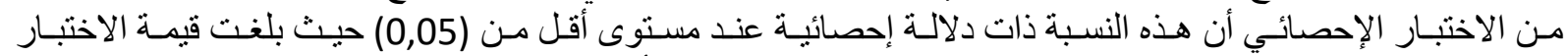

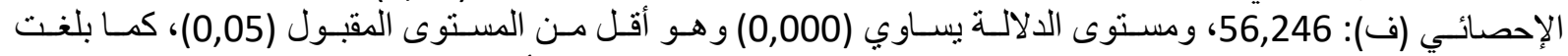

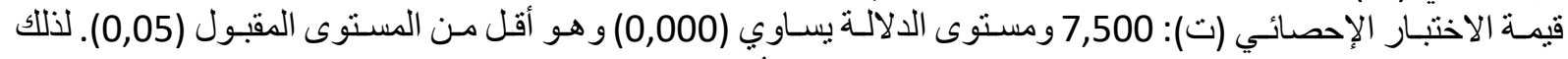

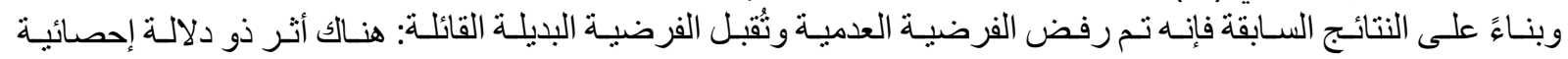

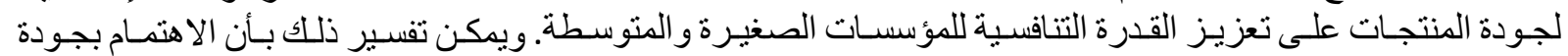

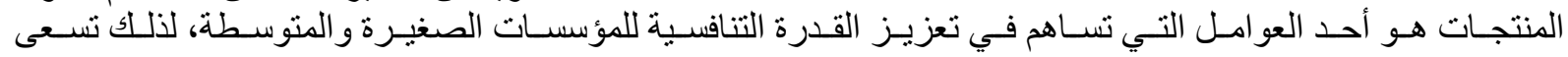

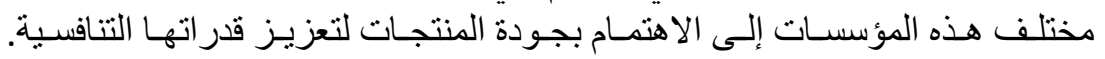

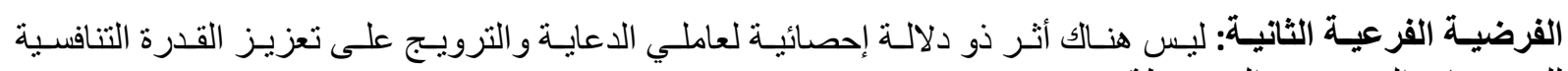

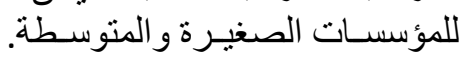

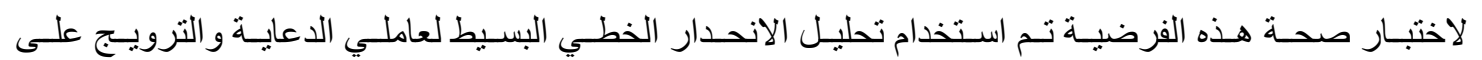

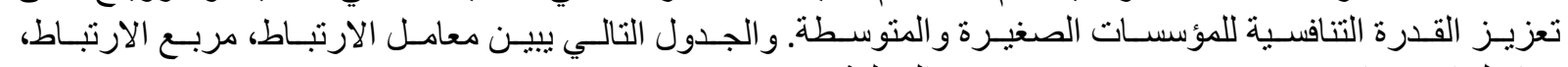

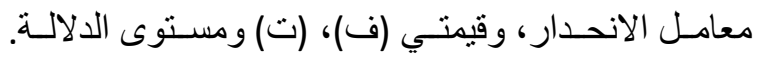

جدول (5): نتائج تحليل الانحدار الخطي البسيط لأثر الاعاية والترويج على تعزيز القدرة التنافسية

\begin{tabular}{|c|c|c|c|c|c|c|c|}
\hline نتيجة ف 0 & الدلالة & قيمة ت & قيمة ف & الاتحدار & التحديد & الارتباط معامل & \\
\hline & & & & 0,480 & & & قيمة الثابت \\
\hline رفض & 0,000 & 8,009 & 64,143 & 1,346 & 0,289 & 0,537 & الاعاية والترويج \\
\hline
\end{tabular}

SPSS.20 المصدر: من إعداد الباحثين بالاعتماد على نتائج برنامجا

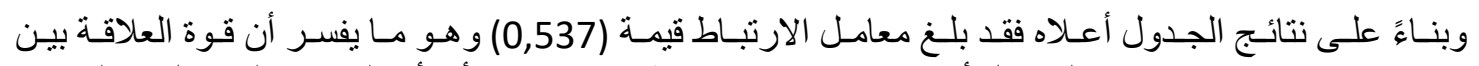

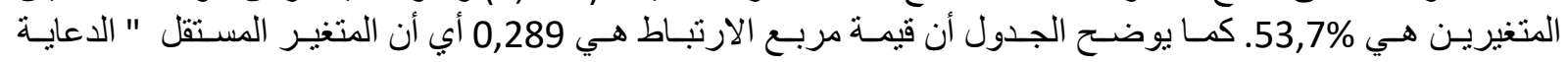

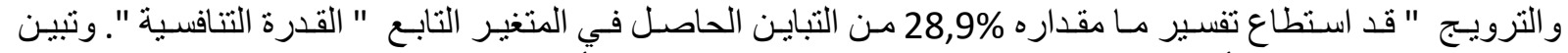

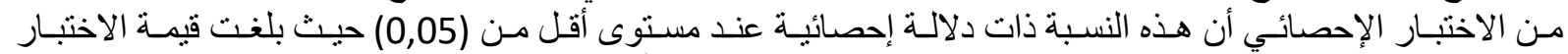

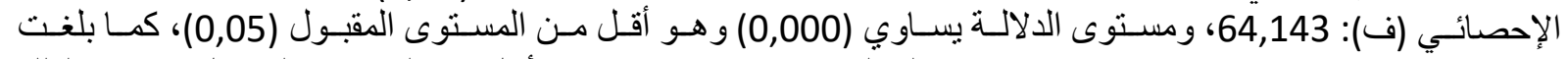

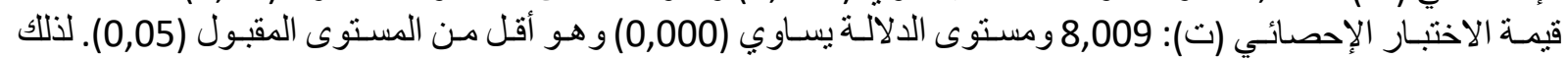

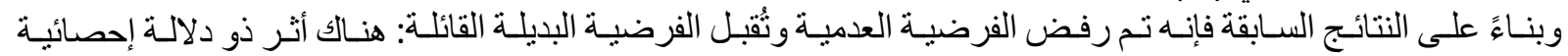

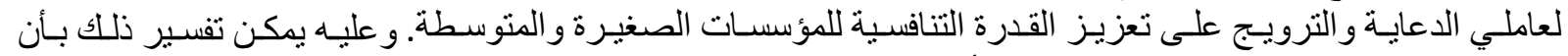

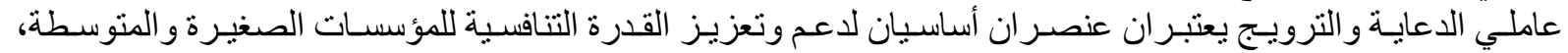

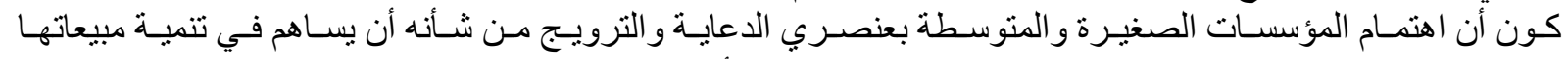

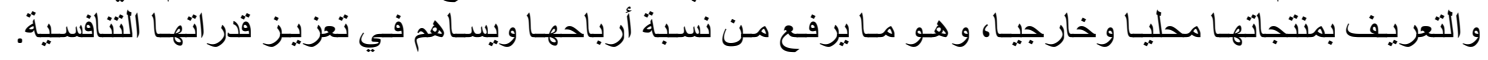


الفرضيـة الفرعيـة الثالثة: ليس هنـاك أثثر ذو دلالــة إحصائيـة لعامل التكنولوجيـا المتقدمـة على تعزيـز القدرة التنافسية

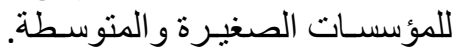

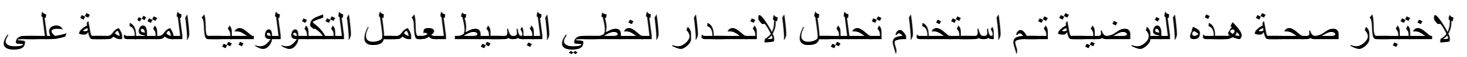

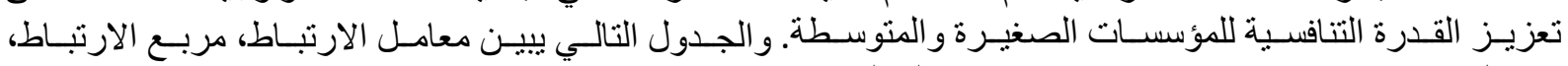

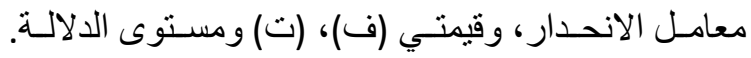

جدول (6): نتائج تحليل الاتحدار الخطي البسيط لأثر التكنولوجيا المتقدمة في تعزيز القدرة التنافية

\begin{tabular}{|c|c|c|c|c|c|c|c|}
\hline نتيجة & مستوى الدلاية & قيمة ت & قيمة ف & الانحدار & التحديد & الارتباط & \\
\hline & & & & 0,318 & & & قيمة الثابت \\
\hline رفض & 0,000 & 5,039 & 25,394 & 0,744 & 0,138 & 0,372 & التكتولومة \\
\hline
\end{tabular}

المصدر: من إعداد الباحثبن بالاعتماد على نتائج برنامج20.SPSS.

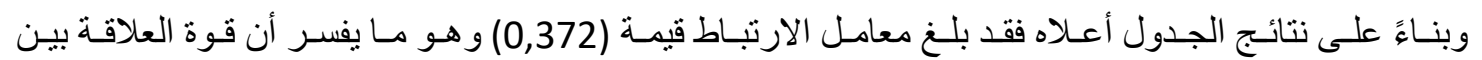

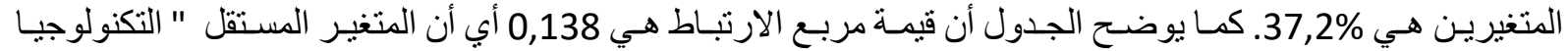

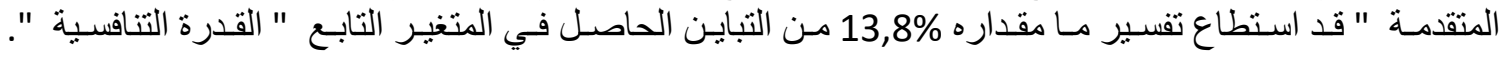

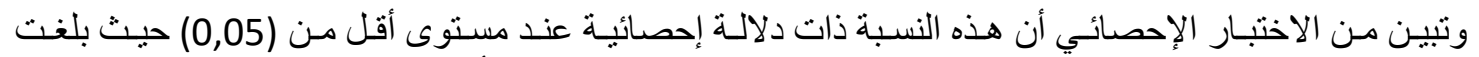

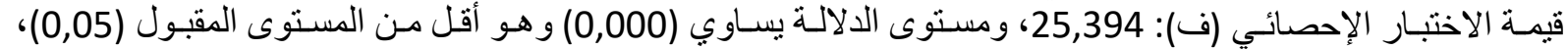

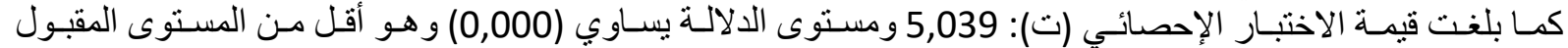

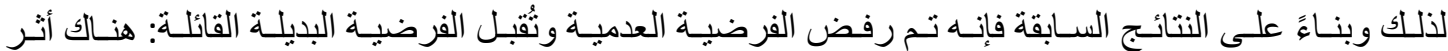

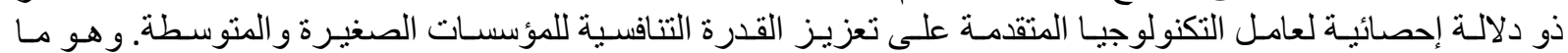

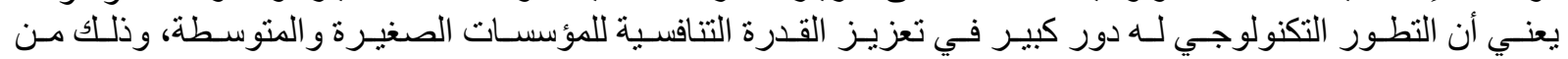

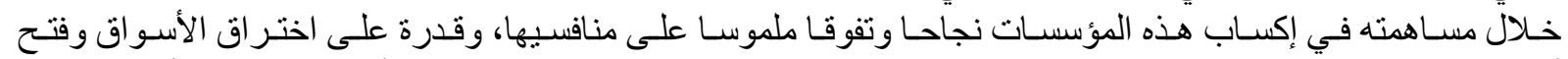

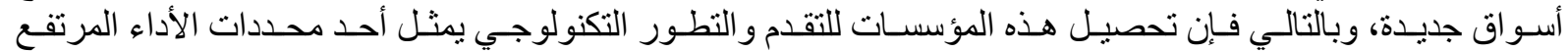

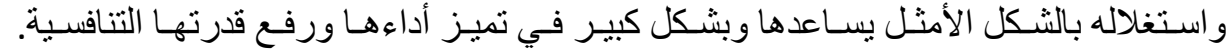

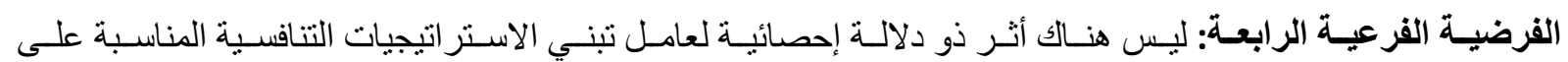

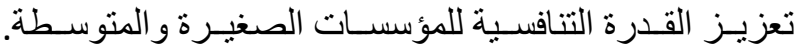

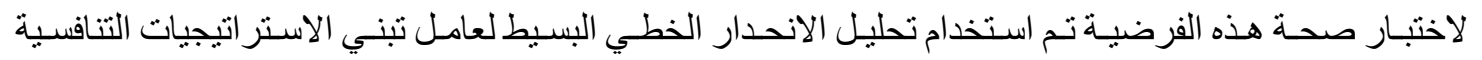

المناسـبة على تعزيـز القدرة التنافسية للمؤسسـات الصغيـرة و المتوسطة.

و الجدول التالي يبين معامل الارتباط، مربع الارتباط، معامل الانحدار، وقيمتي (ف)، (ت) ومستوى الدلالة.

جدول (7): نتائج تحليل الانحدار الخطي البسيط لأثر الاستراتيجيات التنافية في تعزيز القدرة التنافية

\begin{tabular}{|c|c|c|c|c|c|c|c|}
\hline نتيجة & مستوى الدلالة & قيمة ت & قيمة ف & الانحدار & التحديد & الارتباط & \\
\hline & & & & 0,202 & & & قيمة الثابت \\
\hline رفض & 0,000 & 5,458 & 29,787 & 0,907 & 0,159 & 0,398 & الاسترافيجية \\
\hline
\end{tabular}

المصدر: من إعداد الباحثبن بالاعتماد على نتائج برنامج20.SPS. 
شريف ، محي الدين

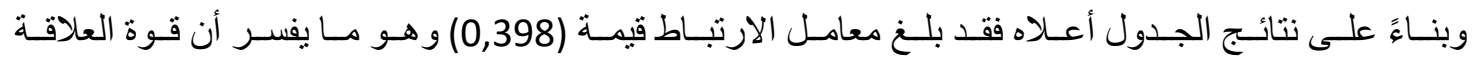

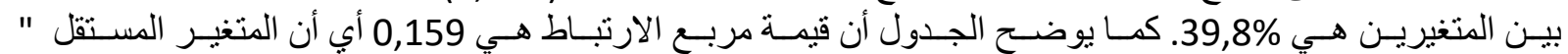

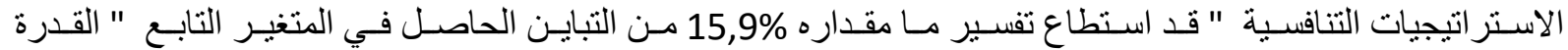

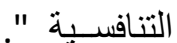

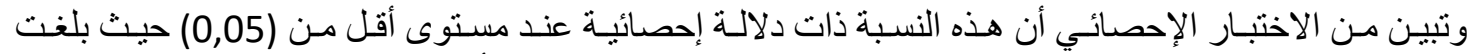

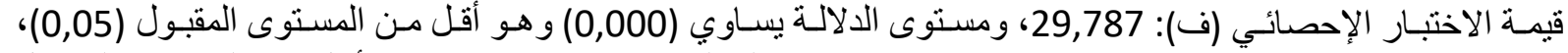

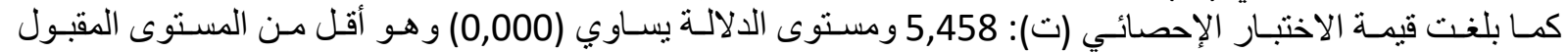

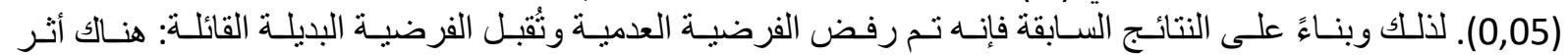

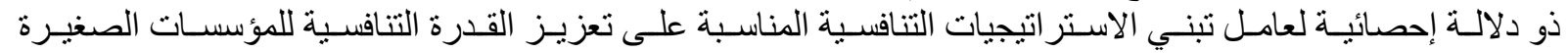
و والمتوسطة.

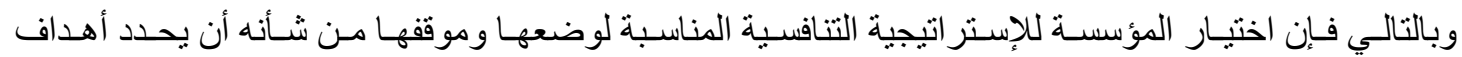

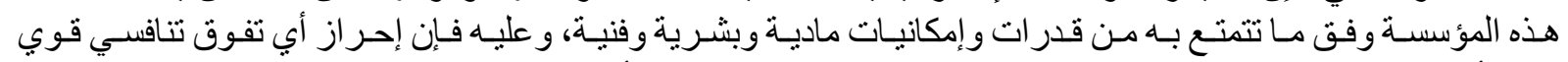

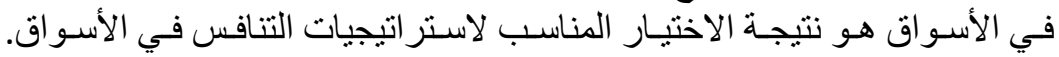

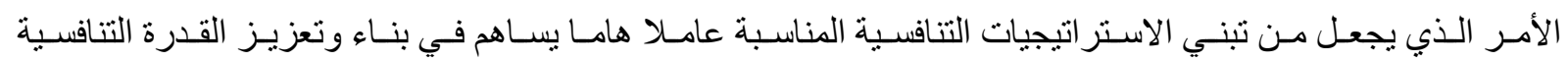

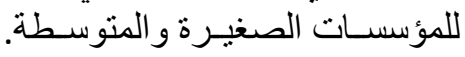

الفرضيـة الفرعيـة الخامسـة: ليس هنـاك أثر ذو دلالـة إحصائيسة لعامل تطويـر أداء العنصـر البشـرب على تعزيـز القدرة

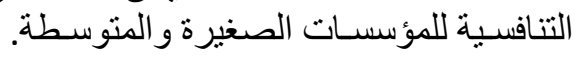

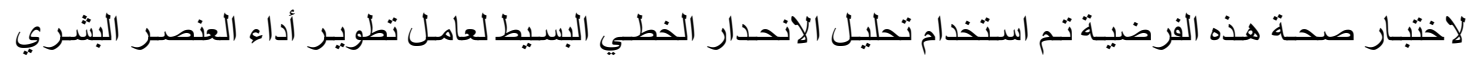

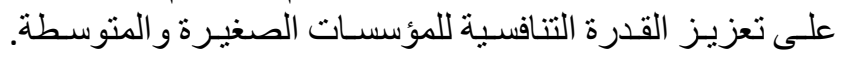

و الجدول التالي بيين معامل الارتباط، مربع الارتباط، معامل الانحدار ، وقيمتي (ف)، (ت) ومستوى الدلالة.

جدول (8): نتائج تحليل الانحدار الخطي البسيط لأثر تطوير أداء العنصر البشري في تعزيز القدرة التنافسية

\begin{tabular}{|c|c|c|c|c|c|c|c|}
\hline نتيجة ف & مستوى الدلاية & قيمة ت & قيمة ف & الانحدار & التحديد & الارتباط & \\
\hline & & & & 0,402 & & & قيمة الثابت \\
\hline رفض & 0,000 & 5,230 & 27,351 & 0,820 & 0,148 & 0,384 & تطوير أداء العنصر \\
\hline
\end{tabular}

SPSS.20 المصدر: من إعداد الباحثين بالاعتماد على نتائج برنامج

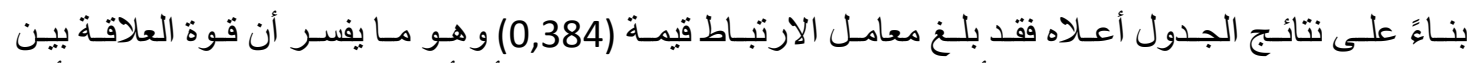

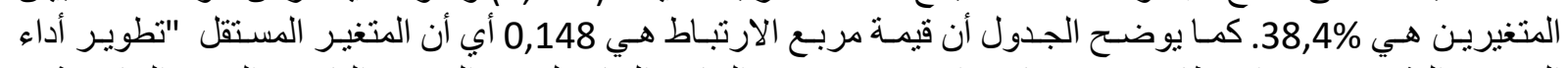

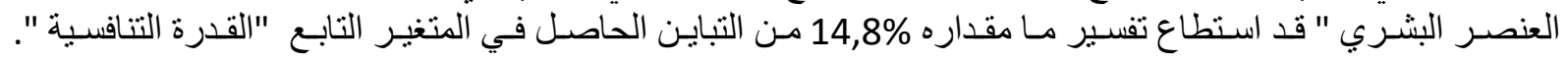

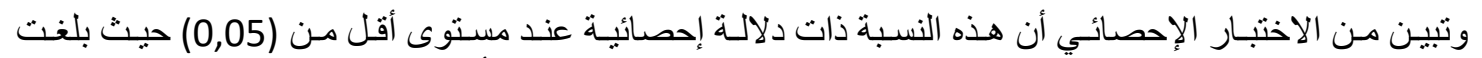

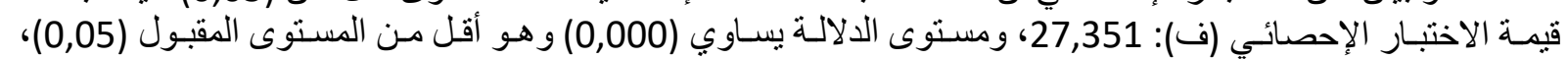

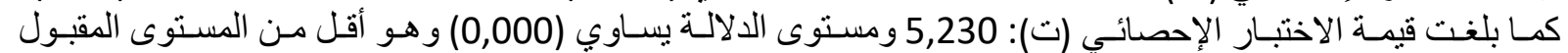

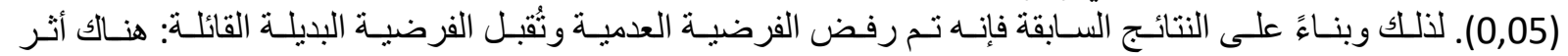

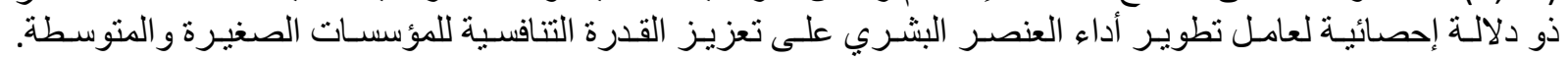

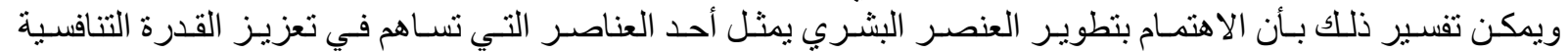
للمؤسسـات الصغيرة ولفيرة المتوسطة الاهنية.

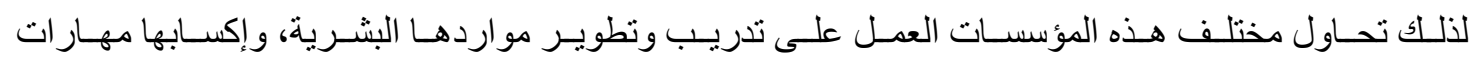

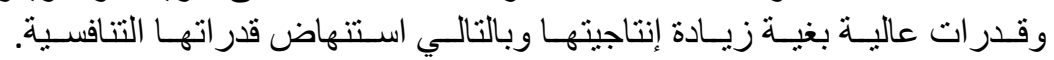




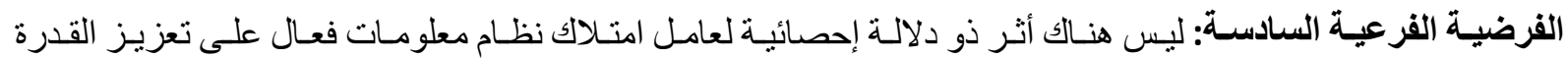

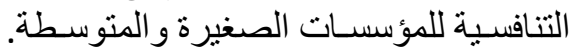

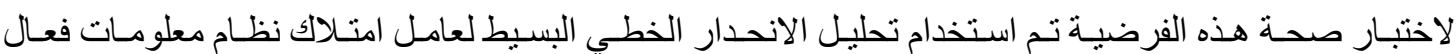

على تعزيز القدرة التنافسية للمؤسسـات الصغيرة ولنية المتوسطة.

و الجدول النتالي يبين معامل الارتباط، مربع الارتباط، معامل الانحدار، وقيمتي (ف)، (ت) ومستوى الدلالة.

جدول (9): نتائج تحليل الانحدار الذطي البسيط لأثر تطوير نظام المعلومات في تعزيز القدرة التنافسية

\begin{tabular}{|c|c|c|c|c|c|c|c|}
\hline نتيجة ف & مستوى الدلالة & قيمة ت & قيمة ف & معامل & معامل & الارتباط & \\
\hline & & & & 0,036 & & & قيمة الثابت \\
\hline رفض & 0,000 & 6,350 & 40,316 & 0,935 & 0,203 & 0,451 & نظام المعلومات \\
\hline
\end{tabular}

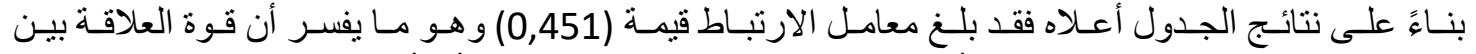

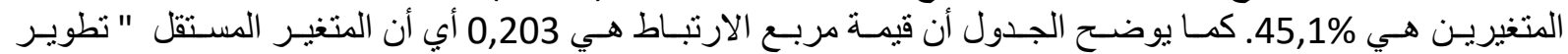

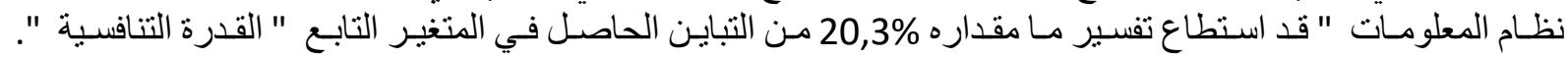

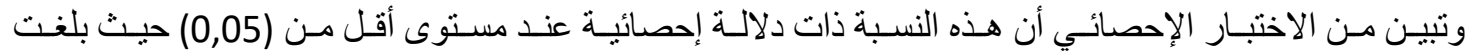

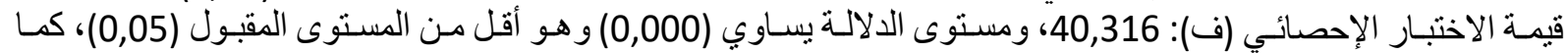

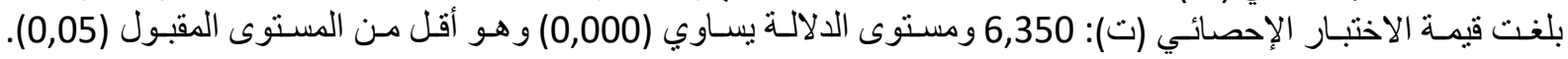

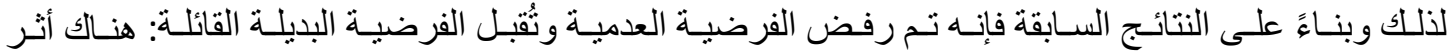

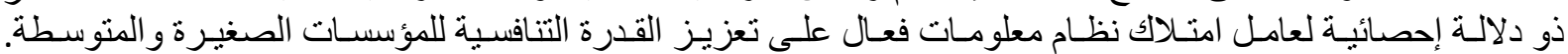

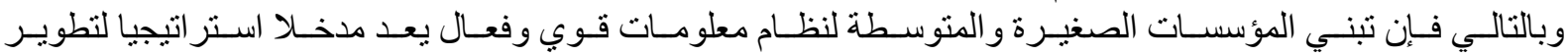

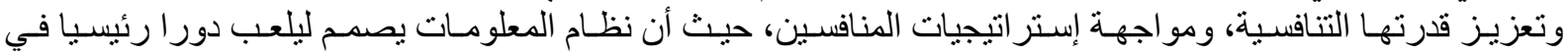

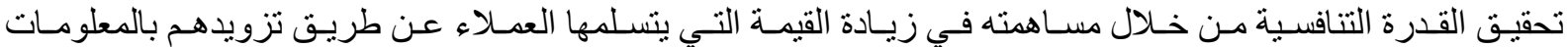

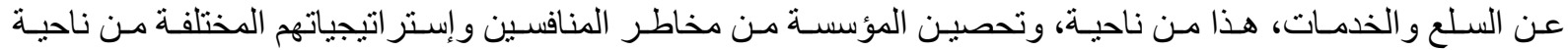

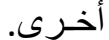

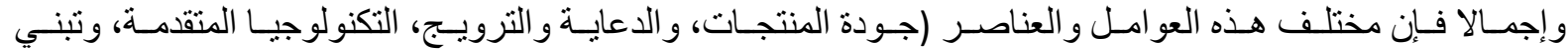

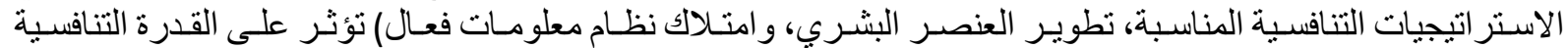

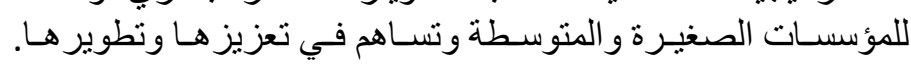

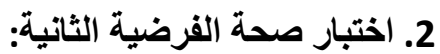

الفرضيـة الصفريـة: القـدرة التنافسـية للمؤسسـات الصغيـرة و المتوسـة ليس لهـا دور و أهميـة في تفعيل وتعظيـم الدور

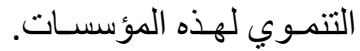

الفرضيـة البليــة: القدرة التنافسية للمؤسسـات الصغيـرة و المتوسـة لهـا دور و أهميـة كبيـرة في تفعيـل وتعظيـم الدور

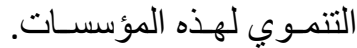

لاختبـار صحسة هذه الفرضيـة تم اسـتخدام اختبـار سنتودنت لعينـة و احدة عند مستوى معنويـة (0,05) والنتائج

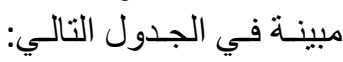

جدول (10): نتائج اختبار ستودنت للفرضية الثانية

\begin{tabular}{|c|c|c|c|}
\hline$T_{t}$ & $T_{\text {, }}$ & sig & درجة الحرية \\
\hline 1,960 & $-20,959$ & 0,000 & 159 \\
\hline
\end{tabular}


شريف ، محي الدين

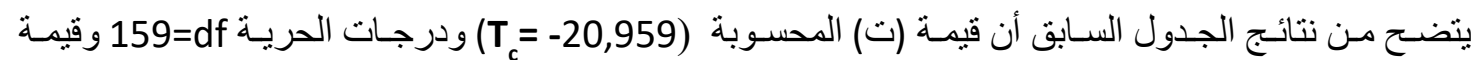
المفو =sig

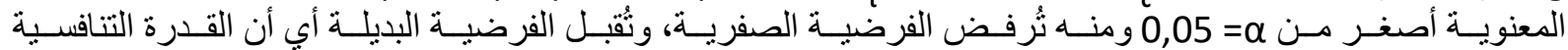

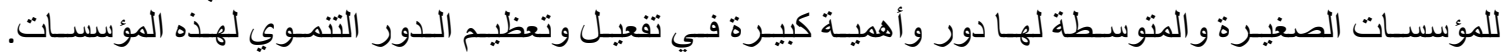
فالمؤسسـات ذات القدرة التنافسـية العاليـة بإمكانهـا المسـاهمة وبأكثر فعاليـة في دفـع عجلـة التتميـة، بمختلف

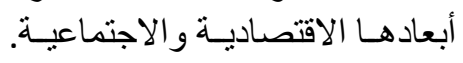
3. اختبار صحة الفرضية الثالثة:

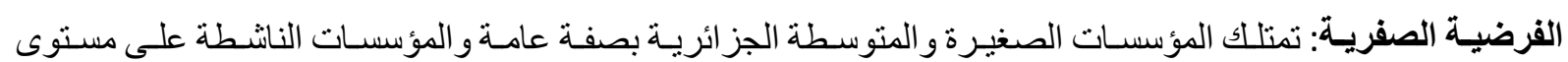

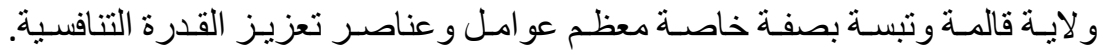

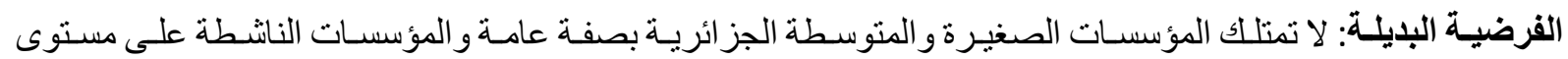

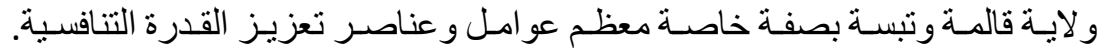
لاختبـار صحسة هذه الفرضيـة تم استخدام اختبـار سـنودنت لعينـة واحدة عند مسـتوى معنويـة (0,05) والنتائجج مبينـة في الجدول التالسي: جدول (11): نتائج اختبار ستودنت للفرضية الثالثة

\begin{tabular}{|c|c|c|c|}
\hline$T_{t}$ & $T_{c}$ & sig & درجة الحرية \\
\hline 1,960 & 18,275 & 0,000 & 159 \\
\hline
\end{tabular}

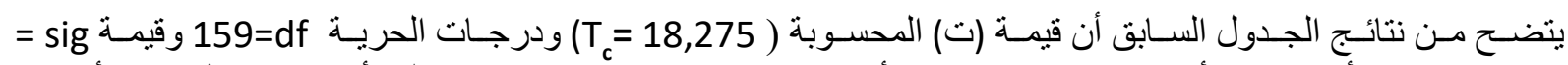

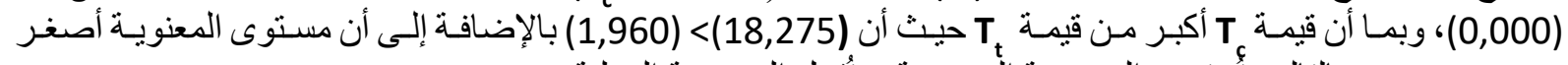

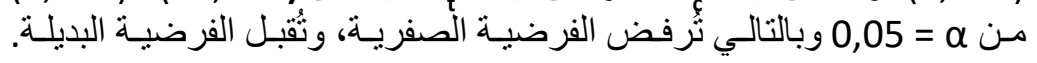

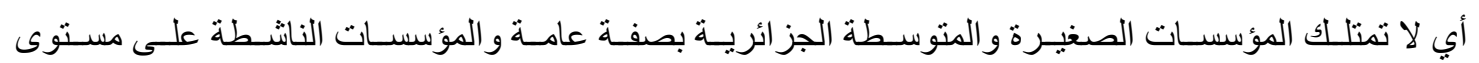

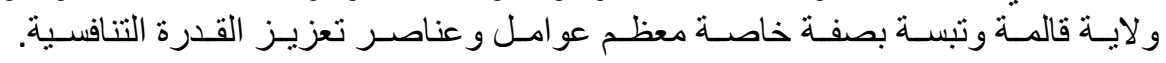

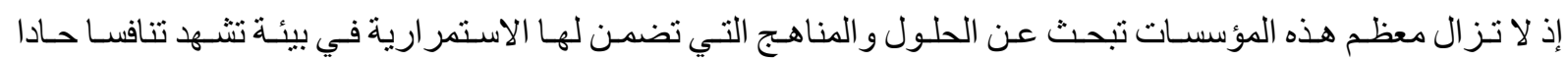

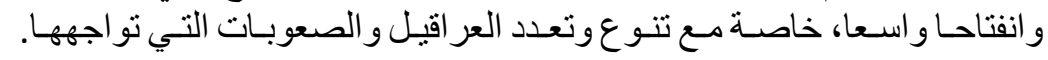

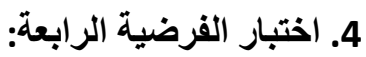

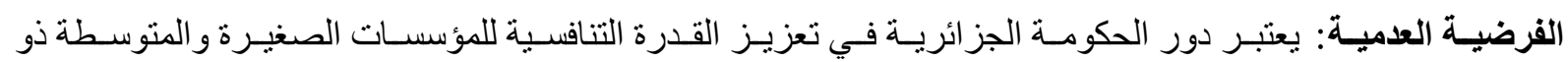

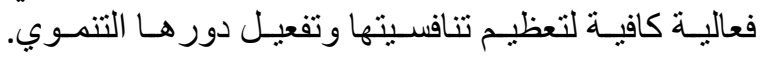

الفرضيـة البديلـة: يعتبـر دور الحكومـة الجزائريـة في تعزيـز القدرة التنافسية للمؤسسـات الصغيـرة و المتوسطة ذو فعاليـة

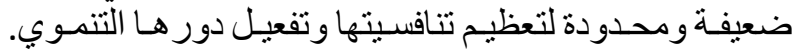

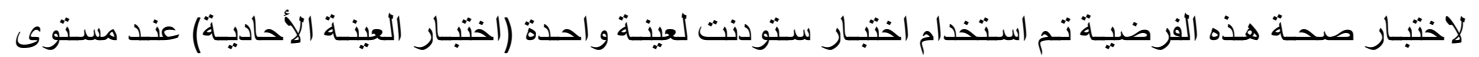

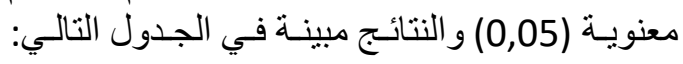

جدول (12): نتائج اختبار ستودنت للفرضية الخامسة

\begin{tabular}{|c|c|c|c|}
\hline$T_{t}$ & $T_{c}$ & sig & درجة الحرية \\
\hline 1,960 & 9,615 & 0,000 & 159 \\
\hline
\end{tabular}




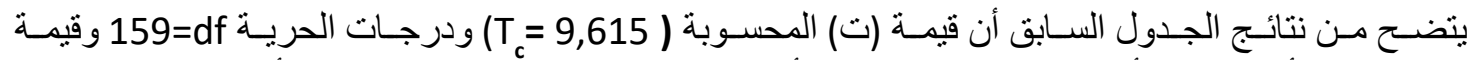

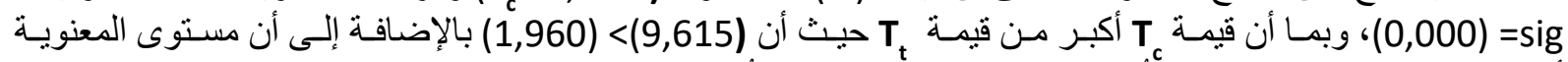

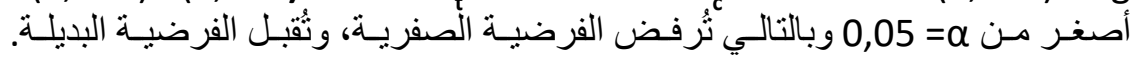

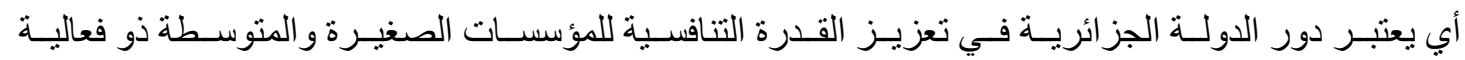

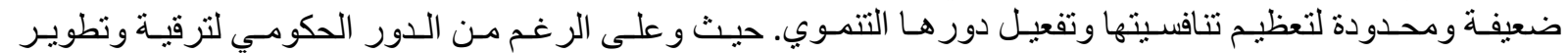

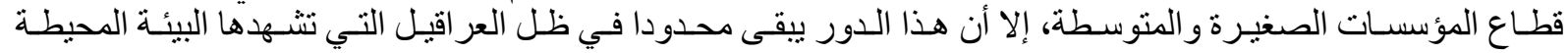
بقطـاع المؤسسـات الصغيـرة و المنوسـة الصنة.

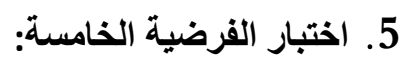

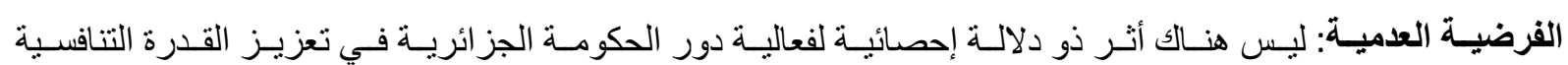

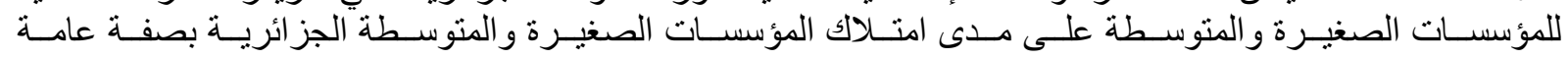

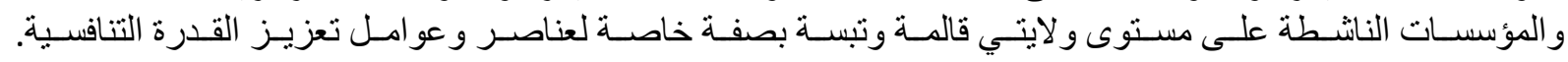

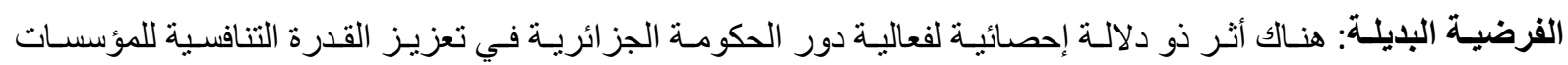

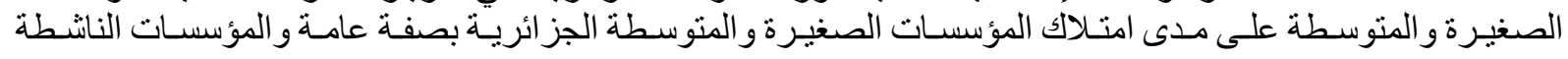

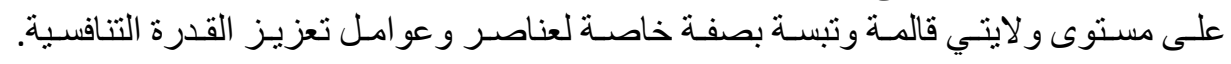

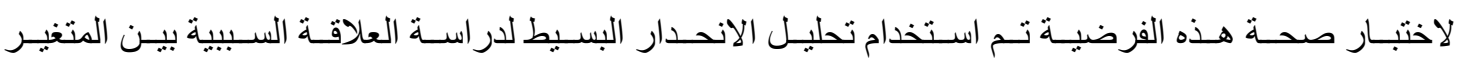

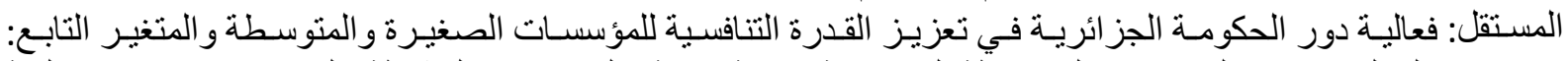

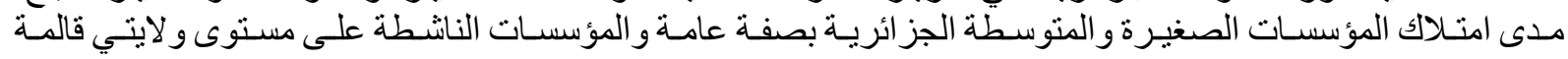

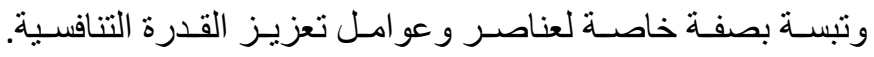

\section{جدول (13): نتائج تحليل الاتحدار البسيط للقرضية السادسة}

\begin{tabular}{|c|c|c|c|c|c|c|c|}
\hline نتيجة & مستوى الدلالة & قيمة & قيمة ف & الانحدار & التحدامل & الارتباط & \\
\hline & & & & 0,86 & & & قيمة الثابت \\
\hline رفض & 0,000 & 10,21 & 104,41 & 0,679 & 0,398 & 0,631 & فعالية دور الحكومة \\
\hline
\end{tabular}

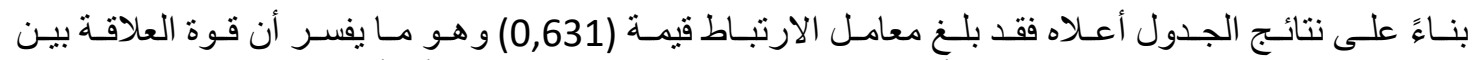

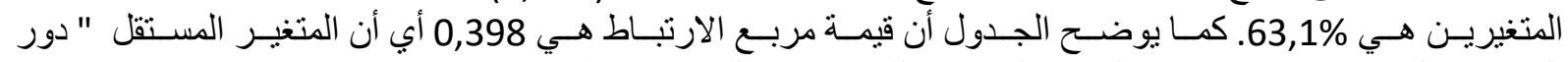

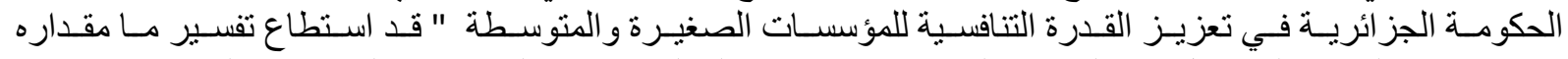

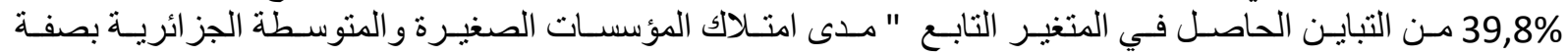

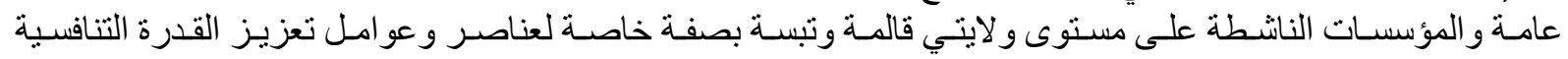

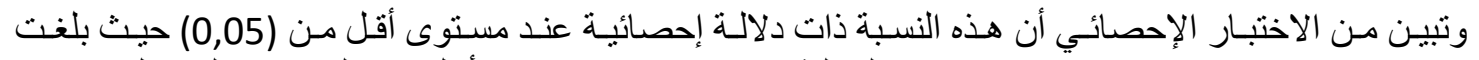

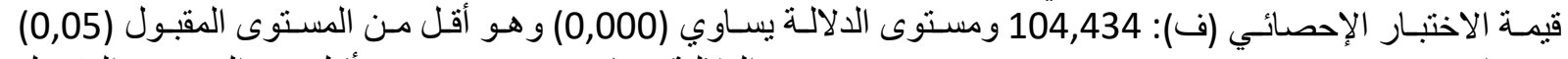

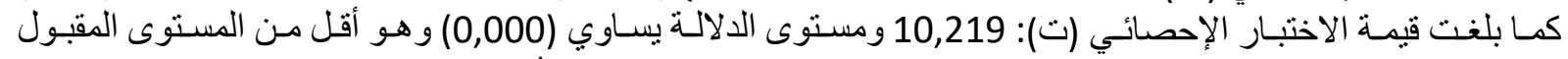

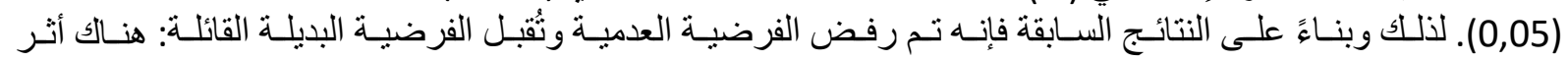

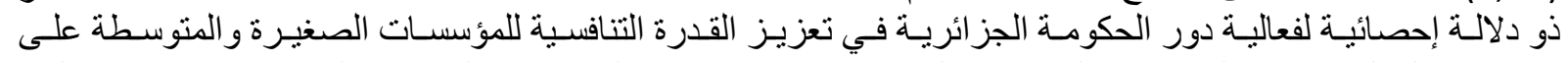

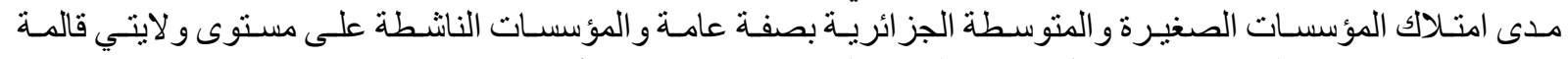

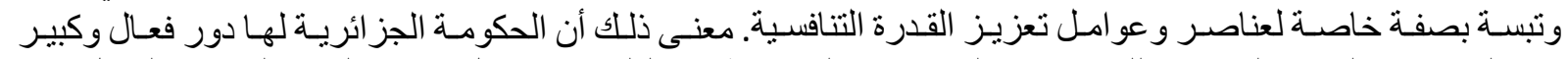

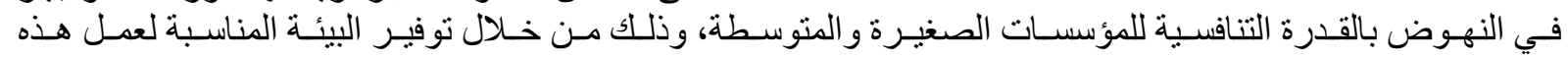

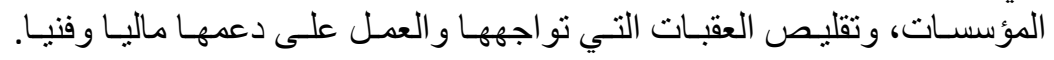


شريف، محي الدين

ثانيا: تحليل بيانات الدراسة

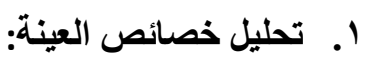

أ. المؤهل العلمي: (متعلم، ثانوي، جامعي): يوضح الجدول رقم (14) النسب المئوية للمؤهل العلمي بالنسبة لعينة

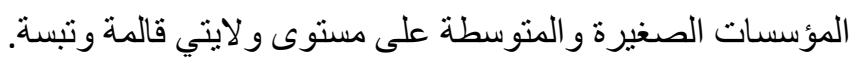

جدول (14):تحليل المؤهل العلمي

\begin{tabular}{|c|c|c|c|}
\hline جامعي & ثانوي & متعلم & البيان \\
\hline 68 & 59 & 33 & 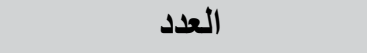 \\
\hline $42,5 \%$ & $36,87 \%$ & $20,62 \%$ & النسبة ضمن إجمالي العينة \\
\hline
\end{tabular}

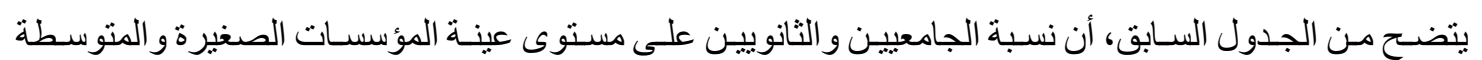

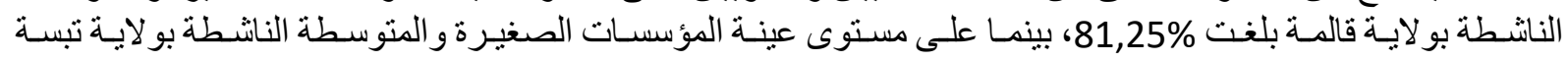

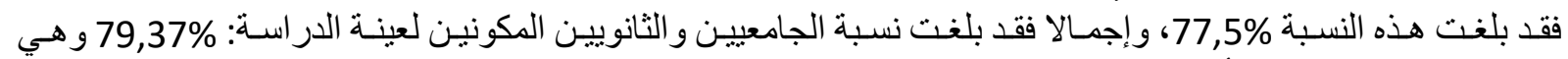

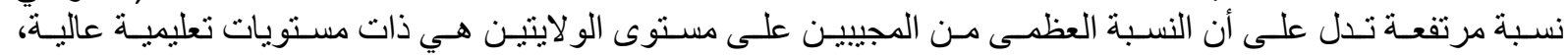

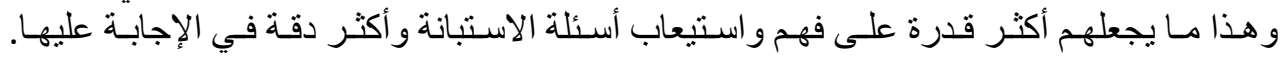

ب. عدد الأصناف: الأصناف التي تنتجها المؤسسة: يوضح الجدول رقانمة (15) النسب المئوية للأصناف التي تتعامل بها

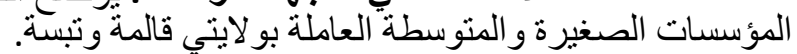

جدول (15):تحليل الأصناف

\begin{tabular}{|c|c|c|c|}
\hline ثُلاثة فأكثر & صنفان & صنف واحد & البيان \\
\hline 17 & 5 & 4 & العدد \\
\hline $65,38 \%$ & $19,23 \%$ & $15,39 \%$ & النسبة \\
\hline
\end{tabular}

نلاحظ من الجدول أعلاه أن المؤسسات الصغيرة والمتوسطة التي تتعامل مع ثلاثة أصناف أو أكثر بالنسبة لعينة

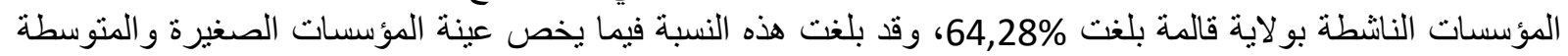

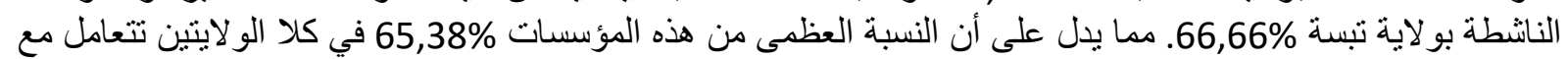

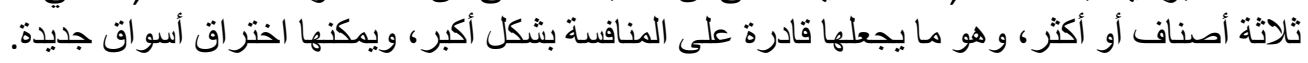

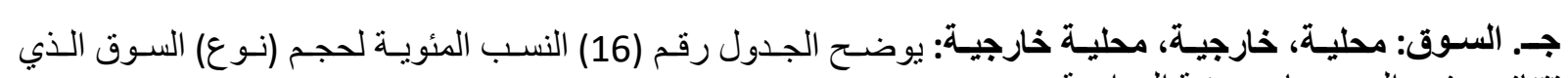

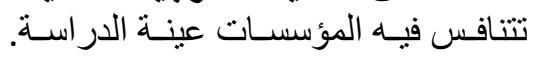

$$
\text { الجدول رقم 16: تحليل السوق }
$$

\begin{tabular}{|c|c|c|c|}
\hline محلية خارجية & خارجية & محلية & البيان \\
\hline 0 & 0 & 24 & العدد \\
\hline $0 \%$ & $0 \%$ & $100 \%$ & لنسبة ضمن إجمالي العينة \\
\hline
\end{tabular}

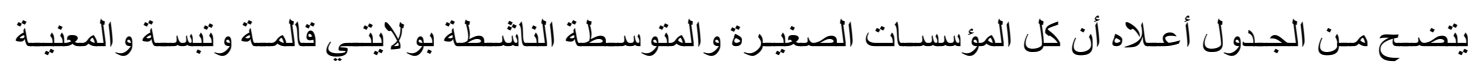

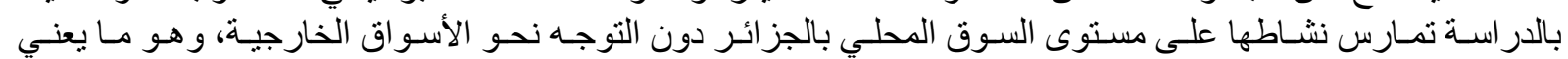

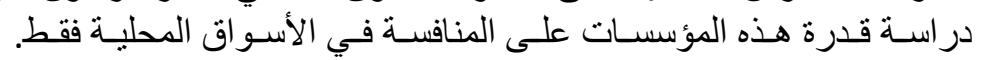




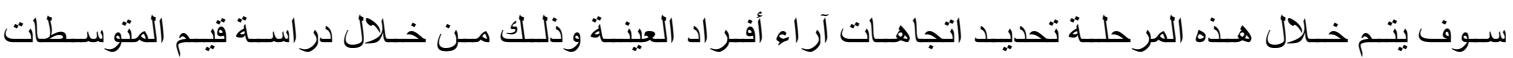

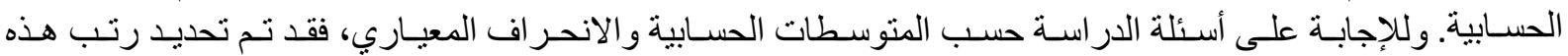

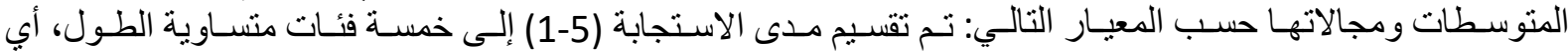

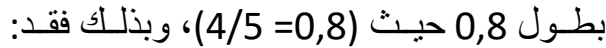

اعتبر المتوسط الحسابي ذو اتجاه موافق بشدة إذا كان ضمن المجال [1 - 1,79].

اعنبر المتوسط الحسابي ذو اتجاه موافق إذا كان ضمن المجال [1,8 - 2,59].

اعتبر المتوسط الحسابي ذو اتجاه لا أدري إذا كان ضمن المجال [2,6 - 3,3].

اعتبر المتوسط الحسابي ذو اتجاه غير موافق إذا كان ضمن المجال [3,4 - 4,1].

اعتبر المتوسط الحسابي ذو اتجاه غير مو افق على الإطلاق إذا كان ضمن المجال [4,2 - 5]

وفيما يلي الإجابة عن أسئلة الدراسة واختبار فرضياتها:

أ. تحليل نتائج المحور الأول: عوامل تعزيز القدرة التنافسية للمؤسسات الصغيرة والمتوسطة

جدول (17): يوضح اتجاه الإجابات المتعلقة بأسئلة المحور الأول

\begin{tabular}{|c|c|c|c|c|c|c|c|c|c|c|c|c|c|}
\hline \multirow{2}{*}{ الاتجاه } & \multirow{2}{*}{ المعياري } & \multirow{2}{*}{ المرجح } & \multicolumn{2}{|c|}{ غير موافق } & \multicolumn{2}{|c|}{ غير موافق } & \multicolumn{2}{|c|}{ لا أدري } & \multicolumn{2}{|c|}{ موافق } & \multicolumn{2}{|c|}{ موافق بشدة } & \\
\hline & & & $\%$ & العدد & $\%$ & العدد & $\%$ & العدد & $\%$ & العدد & $\%$ & العدد & \\
\hline موافق & 1,18 & 2,13 & 6,3 & 10 & 13,1 & 21 & 0,6 & 1 & 47,5 & 76 & 32,5 & 52 & السؤال الأول \\
\hline موافق & 1,22 & 2,33 & 6,3 & 10 & 18,1 & 29 & 5 & 8 & 44,4 & 71 & 26,3 & 42 & السؤال الثاني \\
\hline موافق & 0,97 & 1,87 & 0,6 & 1 & 11,9 & 19 & 2,5 & 4 & 44,4 & 71 & 40,6 & 65 & السؤال الثالث \\
\hline موافق & 1,11 & 2,1 & 1,3 & 2 & 16,9 & 27 & 8,8 & 14 & 36,9 & 59 & 36,3 & 58 & السؤال الرابع \\
\hline موافق & 1,04 & 2,11 & 0 & 0 & 17,5 & 28 & 8,1 & 13 & 43,1 & 69 & 31,3 & 50 & السؤال الخامس \\
\hline موافق & 1,01 & 1,99 & 1,3 & 2 & 12,5 & 20 & 5,6 & 9 & 45,6 & 73 & 35 & 56 & السؤال السادس \\
\hline موافق & 0,48 & 2,09 & & & & & & & & & & & المحور الأول \\
\hline
\end{tabular}

المصدر: من إعداد الباحثين بالاعتماد على مخرجات برنامج SPSS.

نلاحظ من خلال هذا الجدول إجماليا أن هناك موافقة على أن مختلف هذه العناصر والعوامل لها تأثير على العي

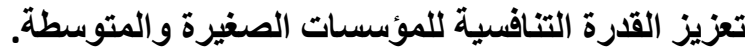

ب. تحليـل نتائسج المحور الثانسي: أهميـة تعزيـز القـدرة التنافسية للمؤسســات الصغيـرة والمتوسطة في تفعيل دورهـا التنموي تحليل 
جدول (18): يوضح اتجاه الإجابات المتعلقة بأسئلة المحور الثاني

\begin{tabular}{|c|c|c|c|c|c|c|c|c|c|c|c|c|c|}
\hline \multirow[t]{2}{*}{ الاتجاه } & \multirow{2}{*}{ الانعياري } & \multirow{2}{*}{ المرجح } & \multicolumn{2}{|c|}{ غير موافق } & \multicolumn{2}{|c|}{ غير موافق } & \multicolumn{2}{|c|}{ لا أدري } & \multicolumn{2}{|c|}{ موافق } & \multicolumn{2}{|c|}{ موافق بشدة } & \\
\hline & & & $\%$ & | العدد | & $\%$ & العدد & $\%$ & العدد & $\%$ & العدد & $\%$ & العدد & \\
\hline موافق & 0,97 & 1,8 & 1,9 & 3 & 8,8 & 14 & 1,9 & 3 & 42,5 & 68 & 45 & 72 & السؤال السابع \\
\hline موافق & 1,01 & 1,99 & 0,6 & 1 & 13,8 & 22 & 5,6 & 9 & 44,4 & 71 & 35,6 & 57 & السؤال الثامن \\
\hline موافق & 1,21 & 2,13 & 4,4 & 7 & 17,5 & 28 & 2,5 & 4 & 38,1 & 61 & 37,5 & 60 & السؤال التاسع \\
\hline موافق & 1,09 & 2,12 & 1,3 & 2 & 17,5 & 28 & 6,3 & 10 & 42,5 & 68 & 32,5 & 52 & السؤال العاشر \\
\hline موافق & 1,23 & 2,25 & 5 & 8 & 18,8 & 30 & 5 & 8 & 38,8 & 62 & 32,5 & 52 & السؤال الحادي \\
\hline موافق & 1,11 & 2,22 & 1,9 & 3 & 18,8 & 30 & 8,1 & 13 & 42,5 & 68 & 28,8 & 46 & السؤال الثاني عشر \\
\hline موافق & 0,55 & 2,08 & & & & & & & & & & & المحور الثاني \\
\hline
\end{tabular}

إجمالا فإنه يتبين من الجدول السابق أن هناك موافقة على أن القدرة التنافسية لها دور كبير وأهمية بارزة في تفعيل الدور التنموي للمؤسسات الصغيرة والمتوسطة. جـ. تحليـل نتائسج المحسور الثالـث: مـدى امتـلاك المؤسســات الصغيـرة والمتوسطة الجزائريـة (قالمة/تبســة) لعوامـل تعزيـز القـدرة التنافسـية جلول (19): يوضح اتجاه الإجابات المتعلقة بأسئلة المحور الثالث

\begin{tabular}{|c|c|c|c|c|c|c|c|c|c|c|c|c|c|}
\hline \multirow[t]{2}{*}{ الاتجاه } & \multirow{2}{*}{ الالحعراف } & \multirow{2}{*}{ المرجح } & \multicolumn{2}{|c|}{ غير موافق } & \multicolumn{2}{|c|}{ غير موافق } & \multicolumn{2}{|c|}{ لا أدري } & \multicolumn{2}{|c|}{ موافق } & \multicolumn{2}{|c|}{ موافق } & \\
\hline & & & $\%$ & العدد & $\%$ & العدد | & $\%$ & العدد & $\%$ & العلد & $\%$ & العدد & \\
\hline غير موافق & 0,9 & 4,2 & 42,5 & 68 & 45 & 72 & 2,5 & 4 & 10 & 16 & 0 & 0 & السؤال الثالث \\
\hline غير موافق & 0,97 & 4,01 & 33,1 & 53 & 48,8 & 78 & 6,9 & 11 & 9,4 & 15 & 1,9 & 3 & السؤال الرابع \\
\hline غير موافق & 1,13 & 3,91 & 35 & 56 & 43,8 & 70 & 3,1 & 5 & 14,4 & 23 & 3,8 & 6 & السؤال الخامس \\
\hline غير موافق & 1,01 & 3,99 & 35 & 56 & 45 & 72 & 4,4 & 7 & 15,6 & 25 & 0 & 0 & السؤال السادس \\
\hline غير موافق & 1,20 & 3,73 & 30 & 48 & 40 & 64 & 8,1 & 13 & 16,9 & 27 & 5 & 8 & السؤال السابع \\
\hline غير موافق & 1,16 & 3,8 & 31,9 & 51 & 41,3 & 66 & 6,3 & 10 & 16,9 & 27 & 3,8 & 6 & السؤال الثامن \\
\hline غير موافق & 1,09 & 3,82 & 29,4 & 47 & 43,8 & 70 & 9,4 & 15 & 15 & 24 & 2,5 & 4 & السؤال التاسع \\
\hline غير موافق & 0,64 & 3,92 & & & & & & & & & & & المحور الثالث \\
\hline
\end{tabular}
المصدر: من إعداد الباحثين بالاعتماد على مخرجات برنامج SPSS.

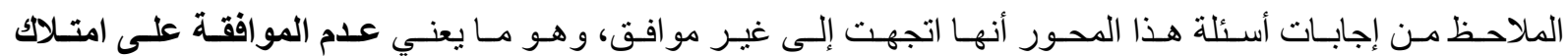

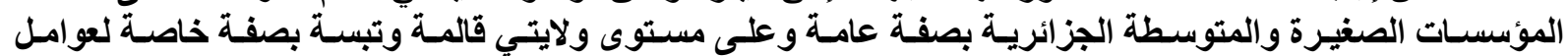
تعزيـز القدرة التتافسية. 


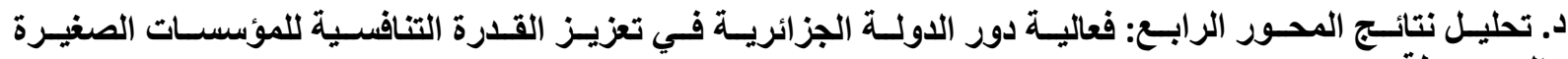

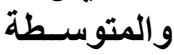

جدول (20): يوضح اتجاه الإجابات المتعلقة بأسئلة المحور الرابع

\begin{tabular}{|c|c|c|c|c|c|c|c|c|c|c|c|c|c|}
\hline \multirow[t]{2}{*}{ الاتجاه } & \multirow{2}{*}{ الالحعراف } & \multirow{2}{*}{ المرجح } & \multicolumn{2}{|c|}{ غير موافق } & \multicolumn{2}{|c|}{ غير موافق } & \multicolumn{2}{|c|}{ لا أدري } & \multicolumn{2}{|c|}{ موافق } & \multicolumn{2}{|c|}{ موافق بثدة } & \\
\hline & & & $\%$ & العدد & $\%$ & العدد & $\%$ & العدد & $\%$ & العدد & $\%$ & العدد & \\
\hline موافير & 1,06 & 3,78 & 27,5 & 44 & 43,1 & 69 & 10 & 16 & 18,8 & 30 & 0,6 & 1 & العشرون الع \\
\hline موافير & 1,23 & 3,69 & 27,5 & 44 & 45 & 72 & 3,8 & 6 & 16,9 & 27 & 6,9 & 11 & و العشادئ \\
\hline موافير & 1,13 & 3,75 & 27,5 & 44 & 45 & 72 & 5,6 & 9 & 19,4 & 31 & 2,5 & 4 & والسؤال الثاني \\
\hline موافير & 1,15 & 3,83 & 33,1 & 53 & 40 & 64 & 8,8 & 14 & 13,8 & 22 & 4,4 & 7 & والسؤ ال الثالث \\
\hline موافير & 1,16 & 3,98 & 38,1 & 61 & 43,8 & 70 & 2,5 & 4 & 9,4 & 15 & 6,3 & 10 & والسؤ ال الر ابع \\
\hline موافق & 1,18 & 2,1 & 3,1 & 5 & 18,1 & 29 & 1,9 & 3 & 39,4 & 63 & 37,5 & 60 & و الخامس العشرون \\
\hline موافقير & 0,69 & 3,52 & & & & & & & & & & & الرابعر \\
\hline
\end{tabular}

إجمـالا فقد لاحظنـا مـن نتائتج الجدول عدم موافقـة على أن جهـود ودور الدولـة الجزائريـة لـه فعاليـة في تعزيز القدرة التنافسية للمؤسسـات الصغيرة والمتوسطة.

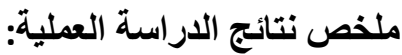

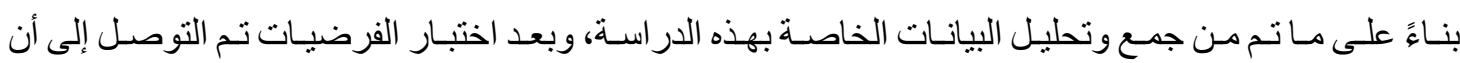

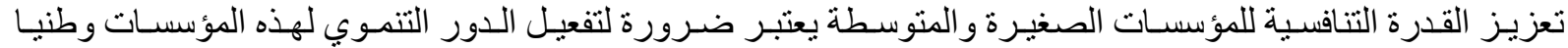
ومحليبا، و النتائُج هي كالآتي:

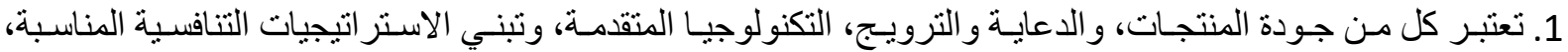

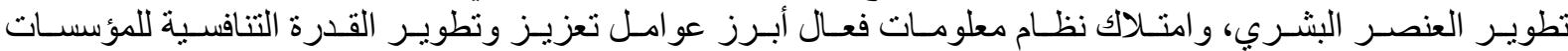

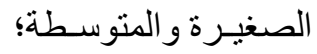

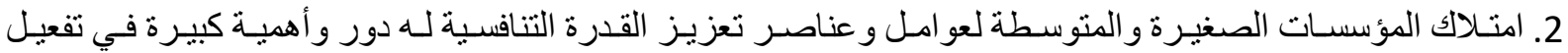

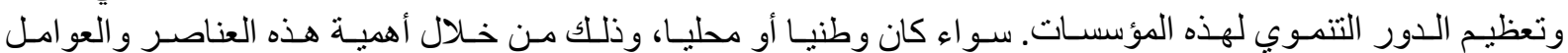

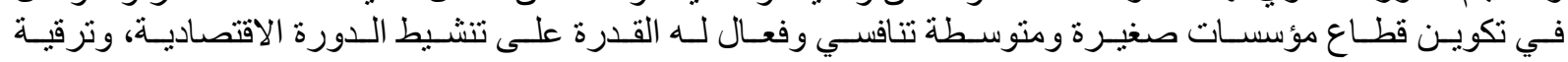

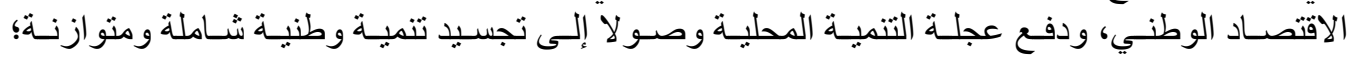

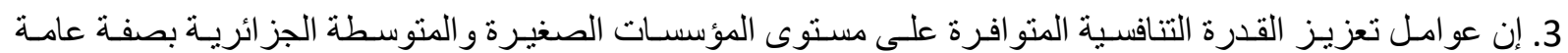

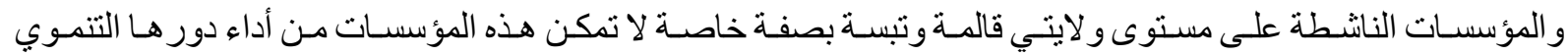

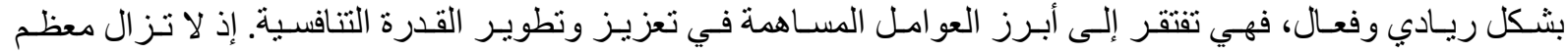

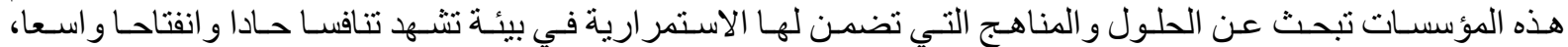

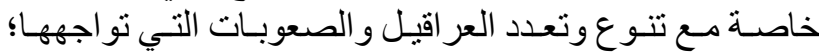
4. يعتبر دور الدولـة الجز ائريـة في تعزيز القدرة التنافسية للمؤسسـات الصغيـرة و المتوسطة ذو فعاليـة ضعيفـة ومحدودة 
شريف ، محي الدين

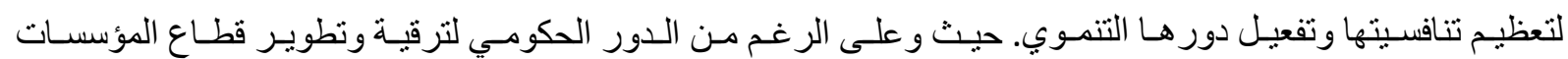

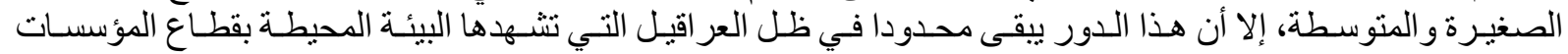
الصغيرة والمتوسطة؛

5. تدنـي القدرة التنافسية للمؤسسـات الصغيـرة و المتوسطة يعود جز ء مهـم منـه إلى عدم تفعيل دور الحكومـة في دعم

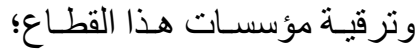

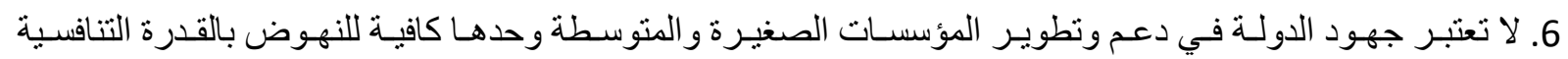

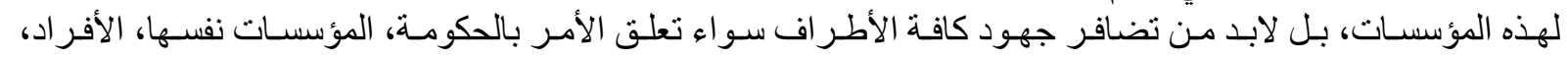

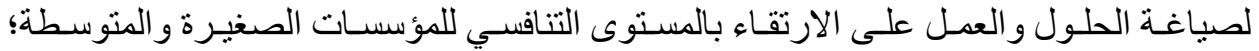

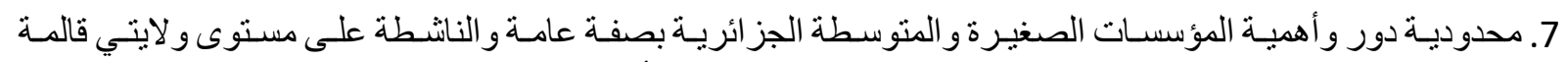

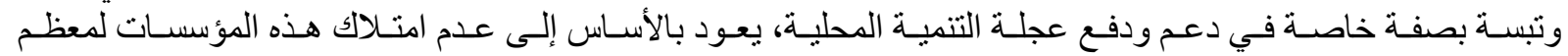

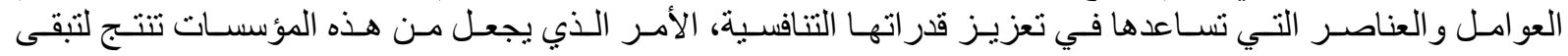

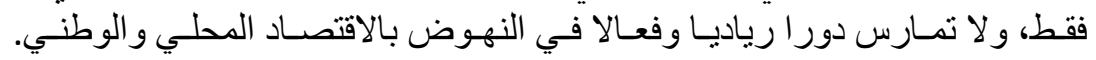

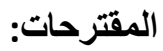

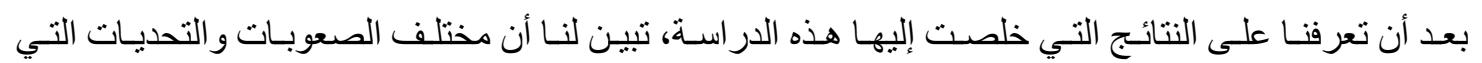

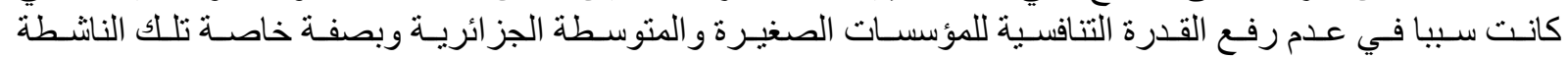

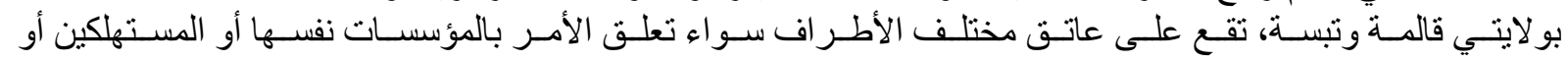

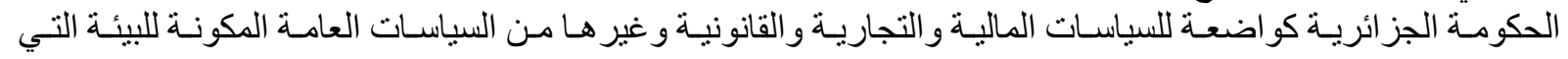

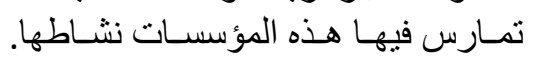

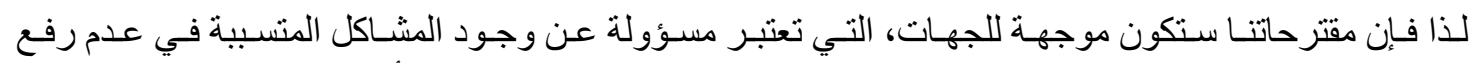

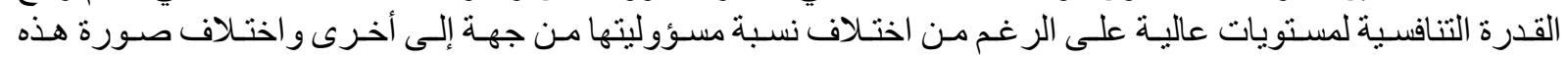

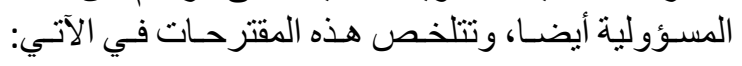

\section{مقترحات موجهة إلى الحكومة وتتمثل في:}

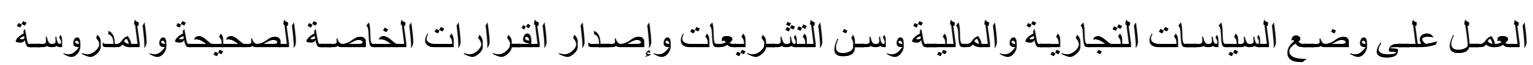

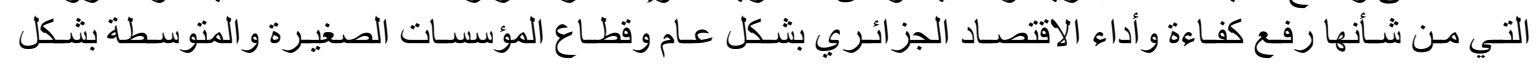

خاص.

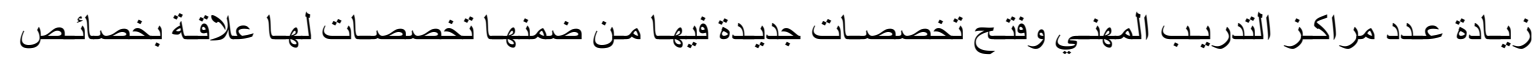

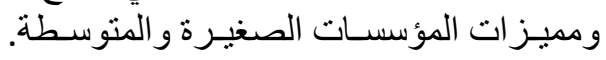

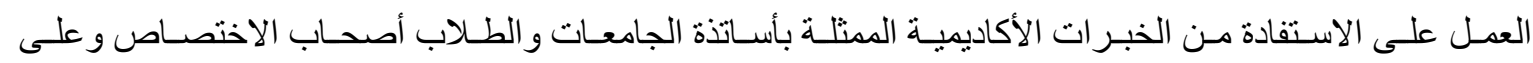

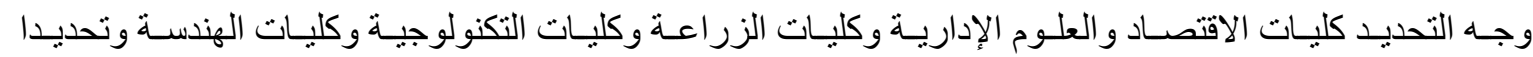

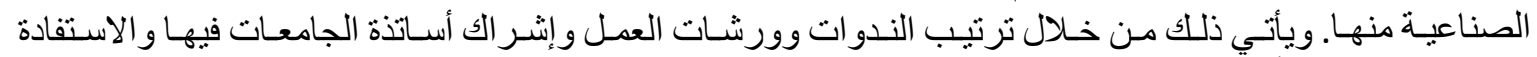

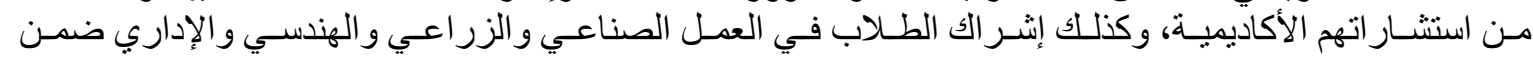

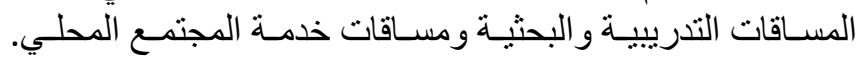

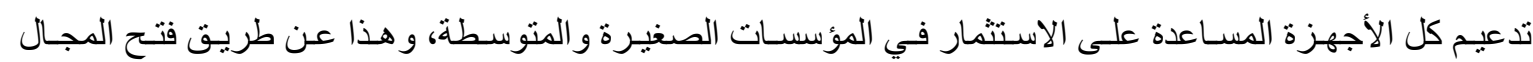

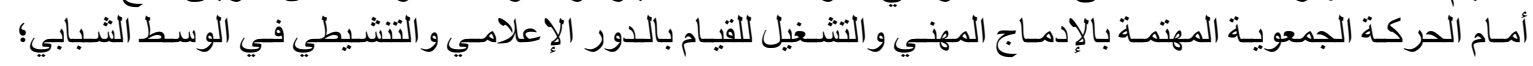

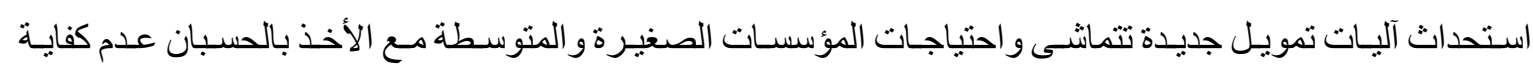
الضمانـات التي تقدمها هذه المؤسيسات

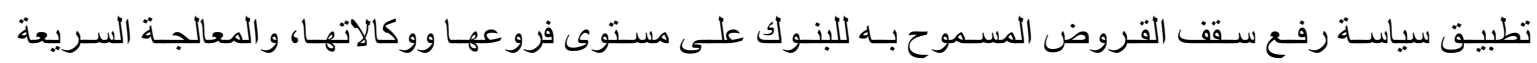

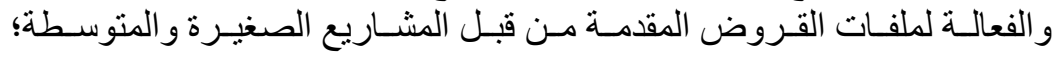

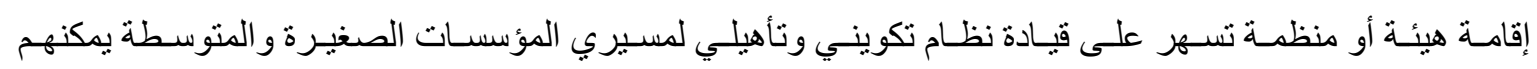


مـن التحكم في أدوات التسـيير الحديثـة ومو اجهـة متغيـرات المحيط؛ دعم المشاركة بين المنظمات الوطنية والأجنبية بغرض جلب الخبرة و التقنية و الأمو ال في الوقت نفسه؛

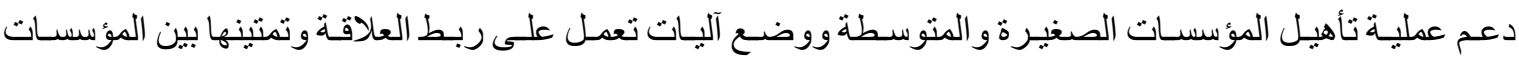

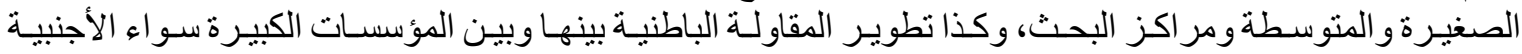

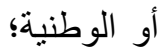

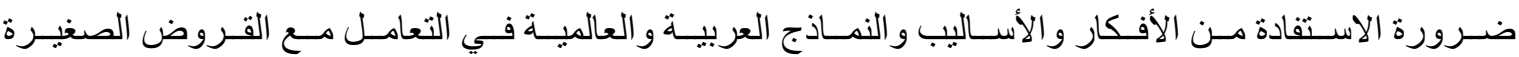

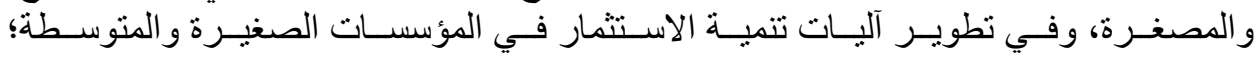

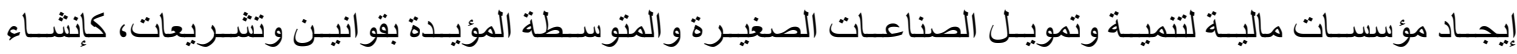

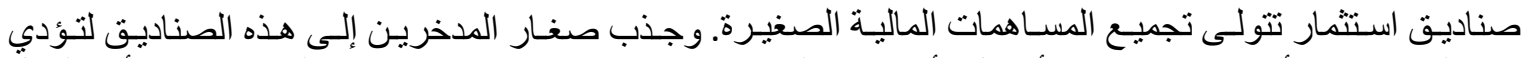

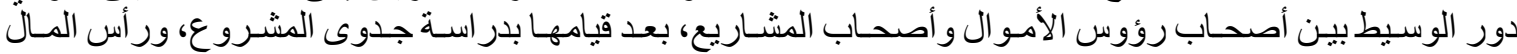

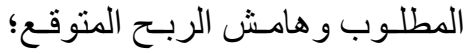

ترقيـة السـوق العقاري بالاعتمـاد على أسـلوب البيـع بالمـز اد العلنهي، مـع الإسـر اع في تسـوية قضـايـا العقـار العالقـة

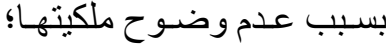

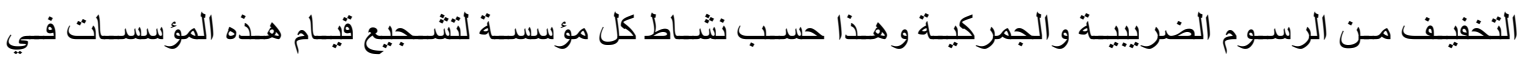
المجـالات الحيويــة.

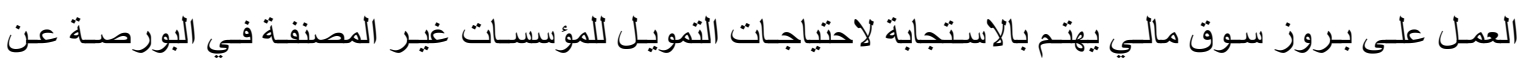

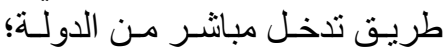

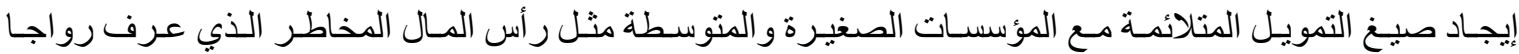

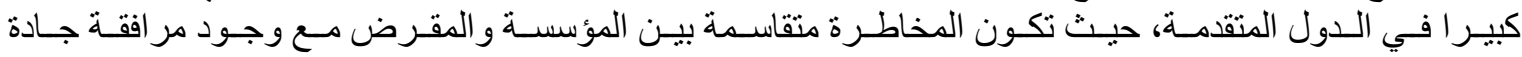

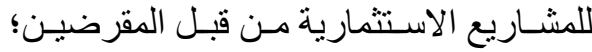

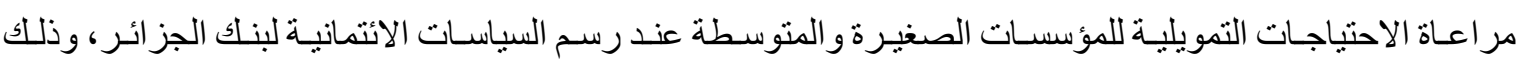

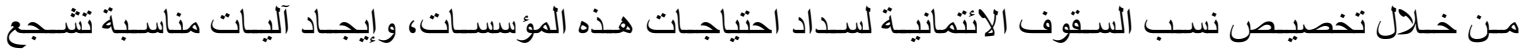

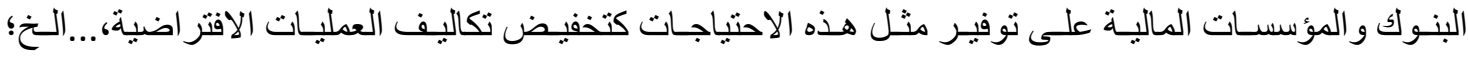

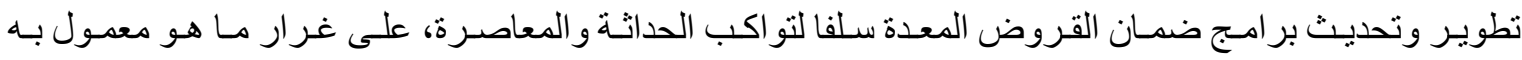

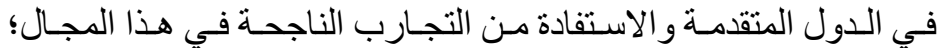

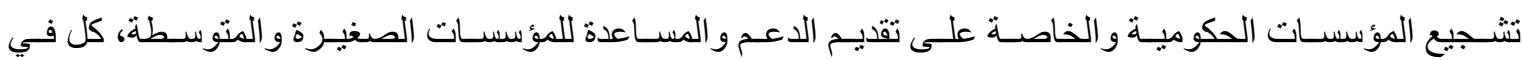

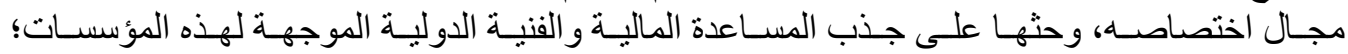

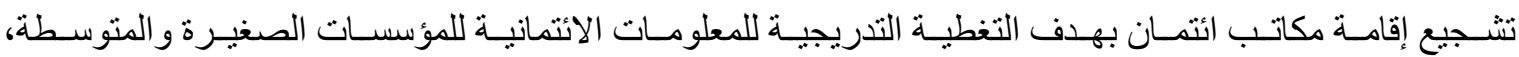

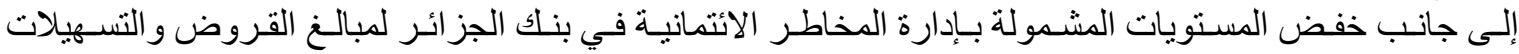

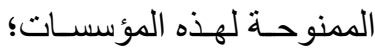

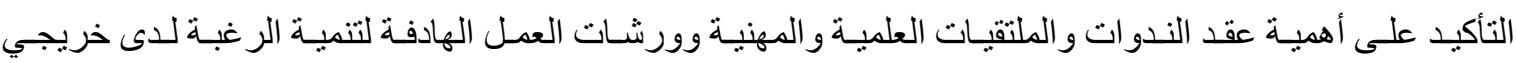

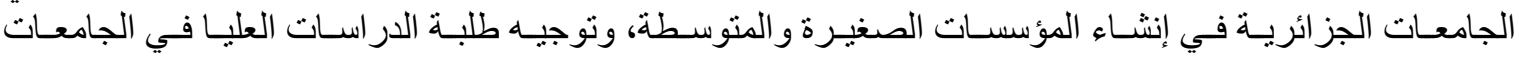

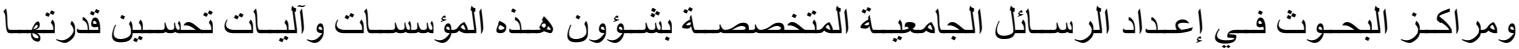
التنافسـية؛

العمل على تفعيل دور الدولة الجز ائرية في رفع قدرة المؤسسات الصغيرة و المتوسطة على المنافسة من خلال: وضوح وشفافية القو انين و التشريعات المنظم للبيئة الاستثمارية المشجعة؛ إنباع سياسات اقتصادية ومالية وتقنية وضريبية متو ازنة ومتر ابطة و إجر اءات إدارية مرنة ومنفتحة؛ 
إعادة النظر في نظام القروض و المنح المقدمة من الدولة، بحيث يصبح دور المصارف المتخصصة أفضل؛

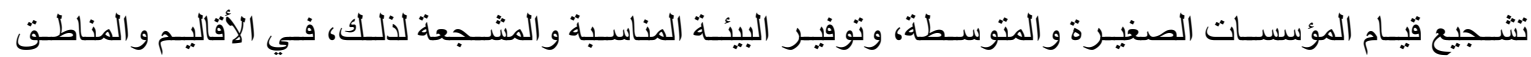
المختلفـة؛

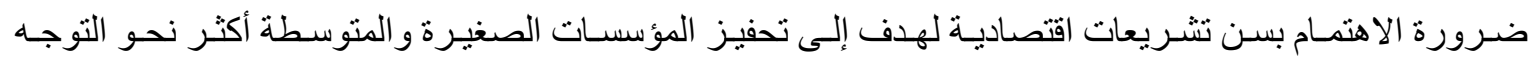

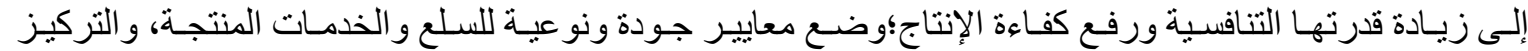

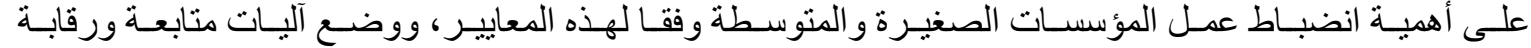
صارمـة؛

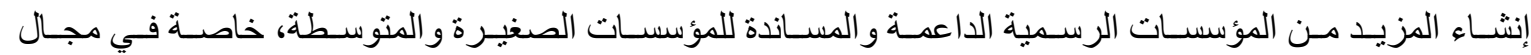

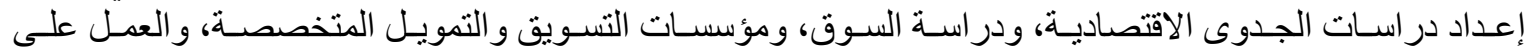

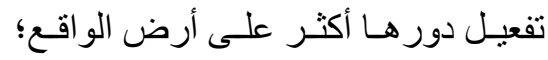

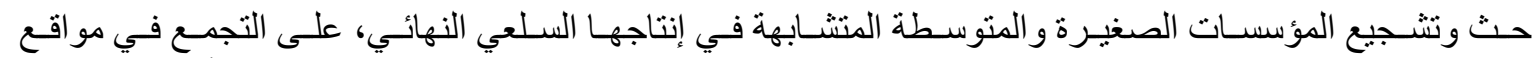

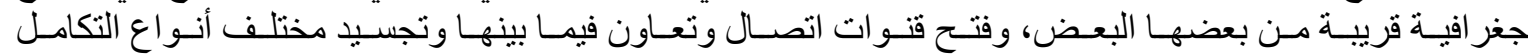
الأمامسي و الخلفي؛

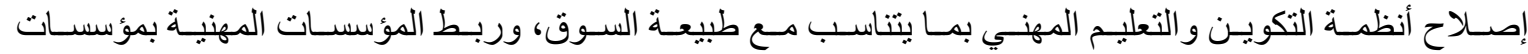

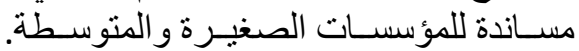

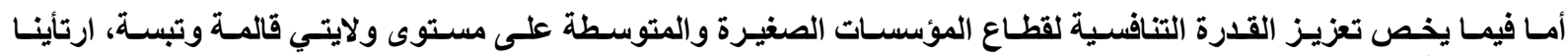
تقديم جملـة مسن التوصيـات نوجزهـا كالآتي:

توفير التسهيلات القانونية و التشريعية مع شرحها وتوضيحها ومحاولة تقليص تفشي ظاهرة البيروقر اطية؛

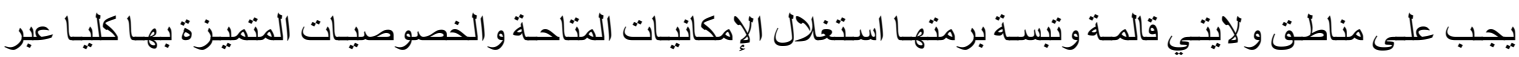

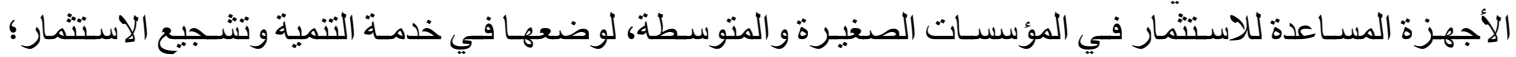

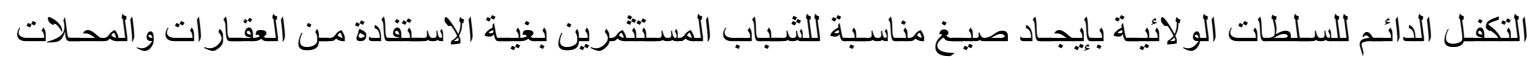

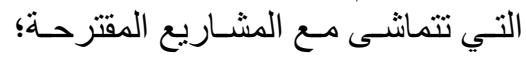

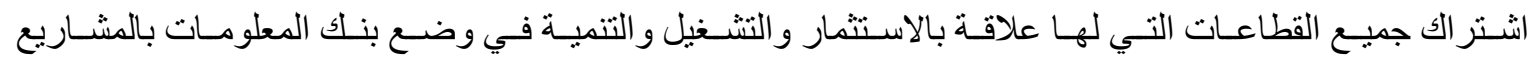

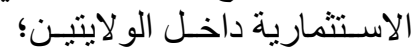

توفير نظام جبائي على مستوى الو لايتين يكون محفز وفحال ويساعد على توفير محيط استثماري ملائم؛ تحسـين مسـتوى الهيـاكل القاعديـة على مسـتوى و لايتـي قالمسة وتبســة بمـا يتـلاءم مـع متطلبـات التطـور الصناعي

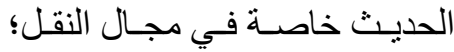

تفعيل دور الإدارة المحليـة بو لايتـي قالمـة وتبسـة في مجـال القيـام بالدر اسـات و إقامـة المـدن، والتجمعـات الصناعيـة

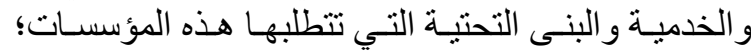

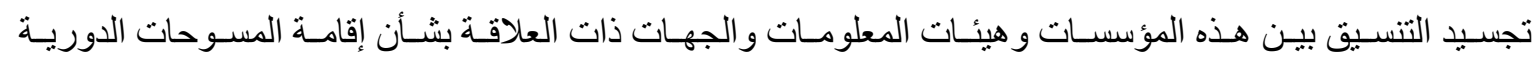

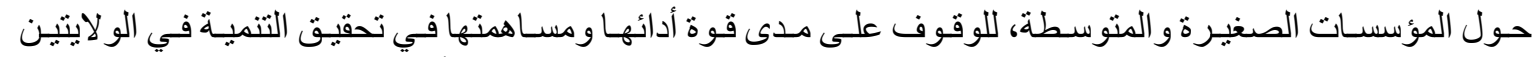

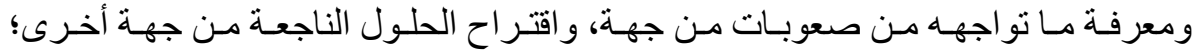

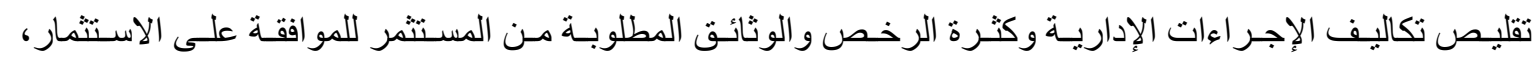

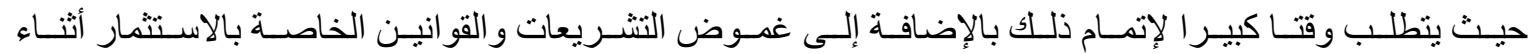

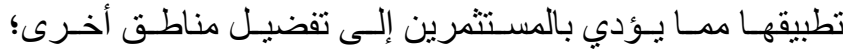

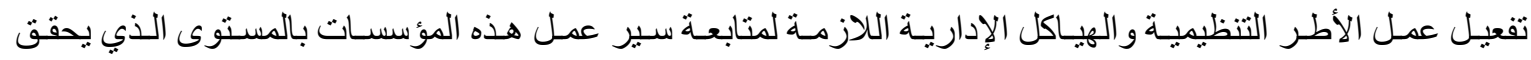

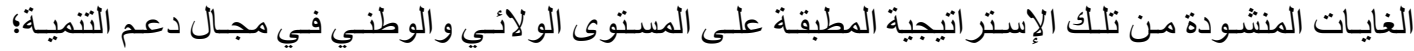




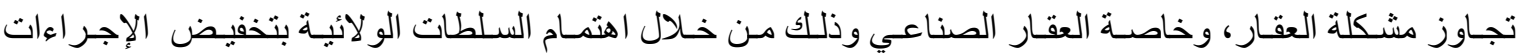
المصاحبـة لإنثـاء العقار.

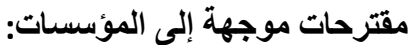

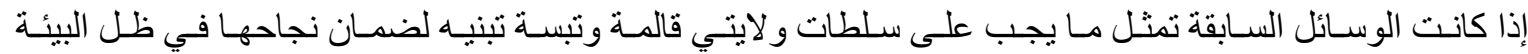

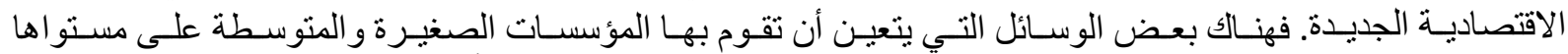

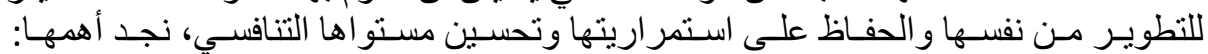

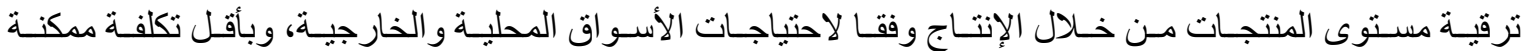

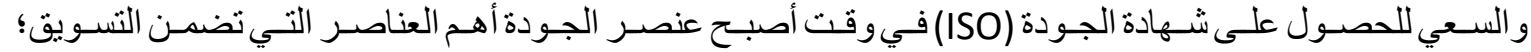

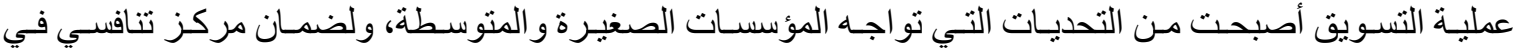

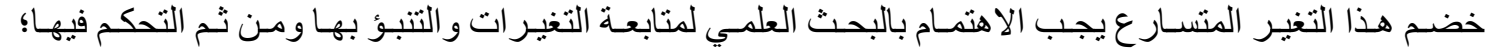

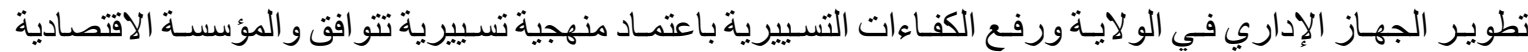

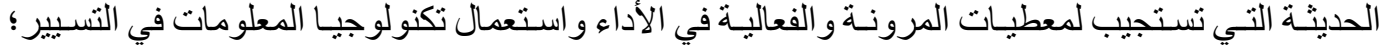
تقليل الاعتماد على الإدارة العائلية للمؤسسات الصغيرة و المتوسطة، وتبني نظم إدارية أكثر حداثة وتطور ا؛

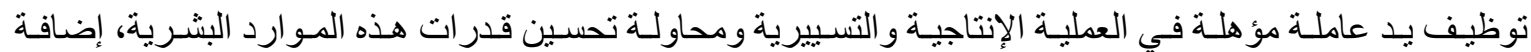

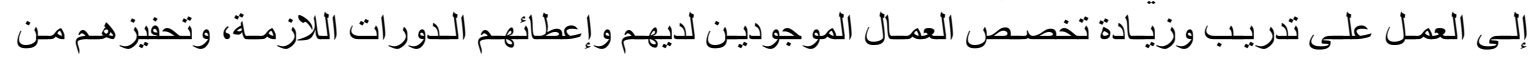

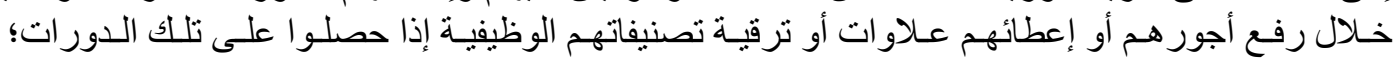

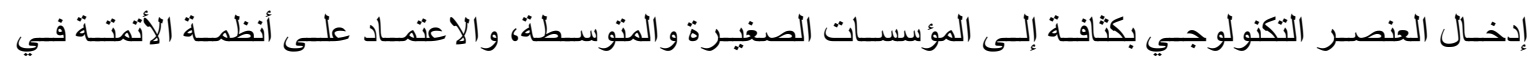
الإنتـاج ولـو بشـكل تدريجـي؛ زيادة التخصص في الإنتاج و عدم إنتاج الأصناف المتعددة وذلك بهدف رفع كفاءة وأداء صناعاتهج؛

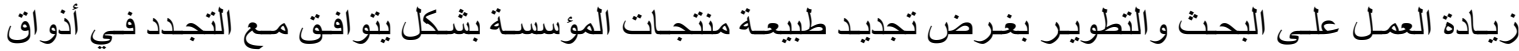

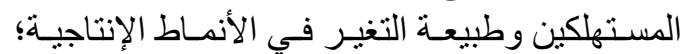

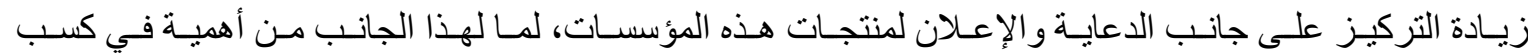

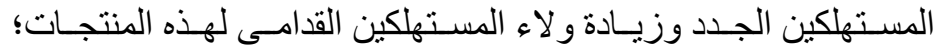

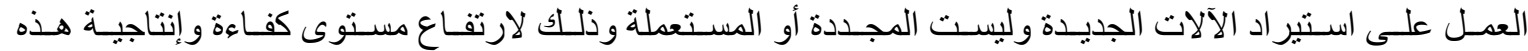
الآلات؛

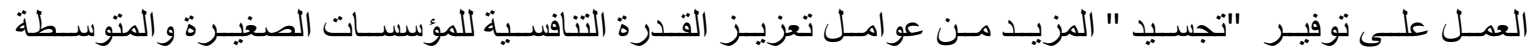

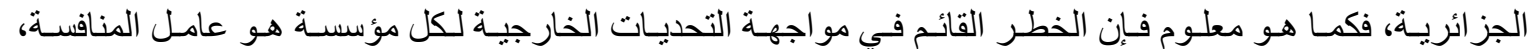

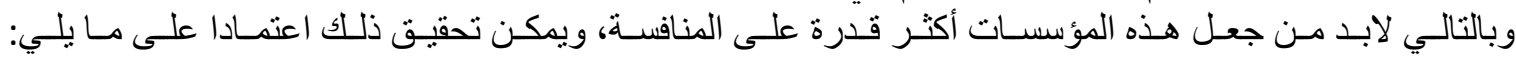

الارتقاء بتصميم المنتجات وجودتها؛

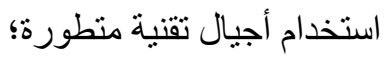

إعادة النظر بخطة القوى العاملة من خلال التدريب و التحفيز لزيادة إنتاجية العمل كما ونو عا؛

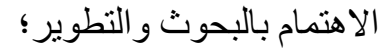

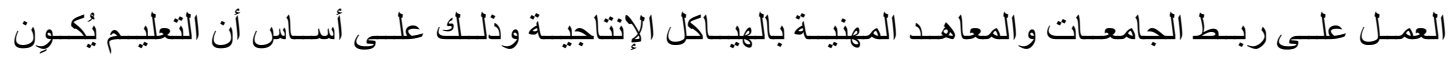

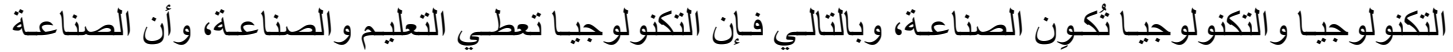


الإطلاع على التقنيات الحديثة والتطوير الفني المستمر للآلات وطرق الإنتاج؛

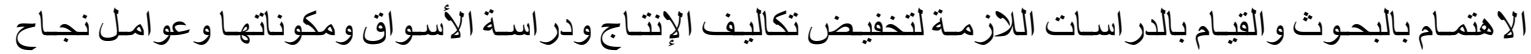
المنافسـة في كل منها؛

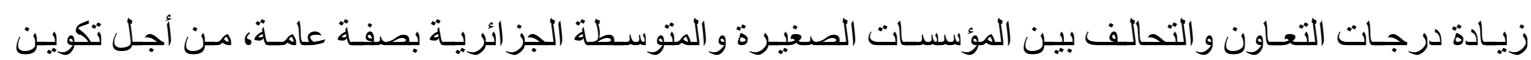
كيانـات أكبر قـادرة على منافسـة مثبلاتهـا؛

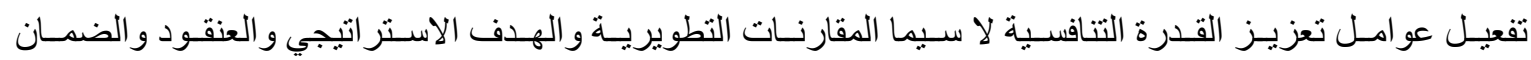

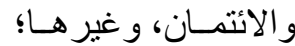

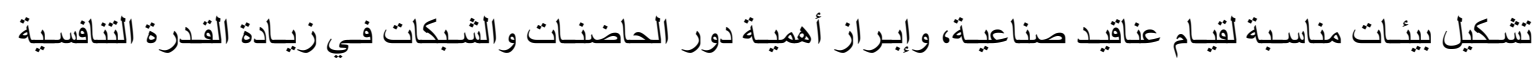
لهذه المؤسسات. مقترحات موجهة إلى المستتهلكين:

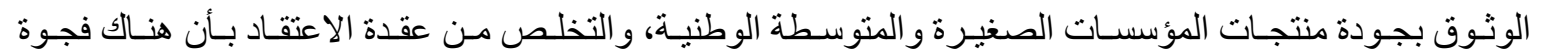

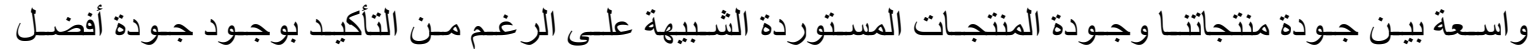

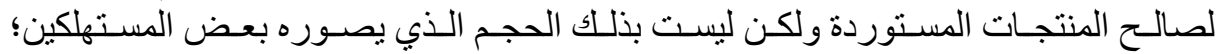

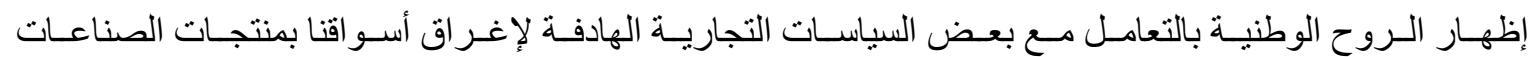

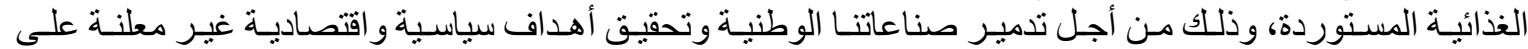
المدييـن القصيـر و المتوسـط وذلئ

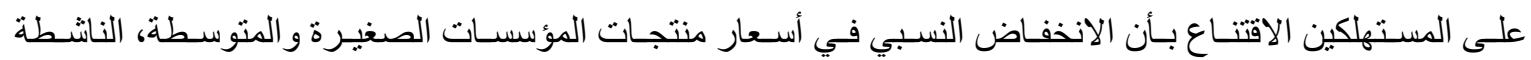

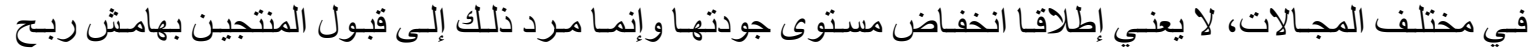
ضئيلـل وانخفاض التكاليف النسبية في إنتاجها؛

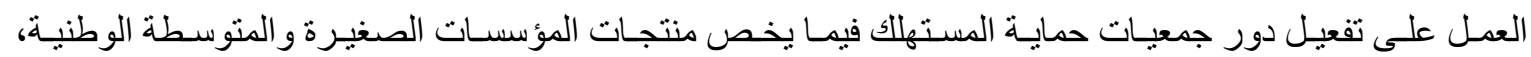

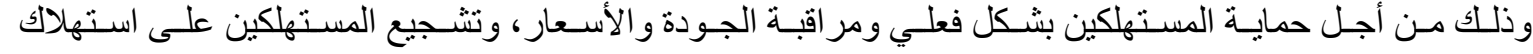
المنتجـات المحليـة وذلـك بالتعـاون مـع الهيئـات الرســية.

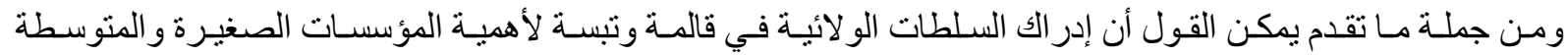

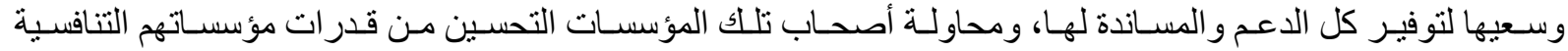

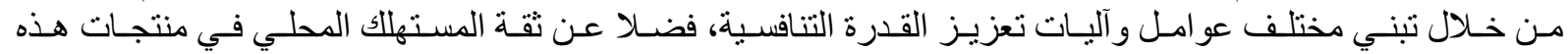

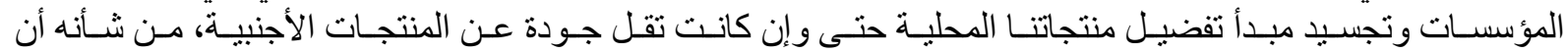

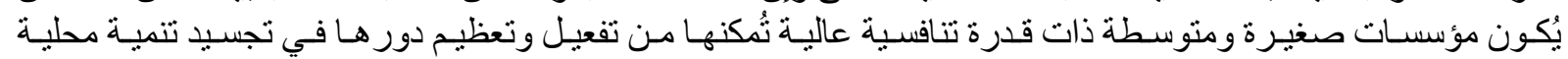

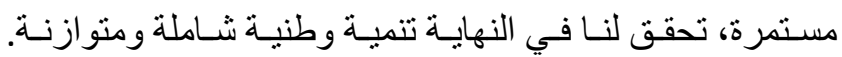

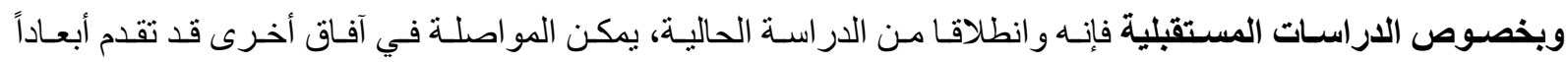

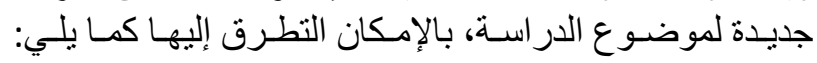

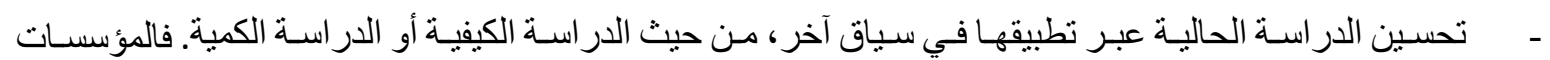

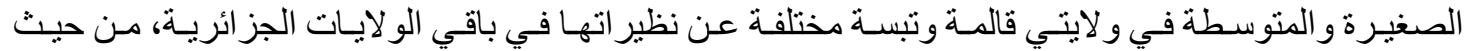

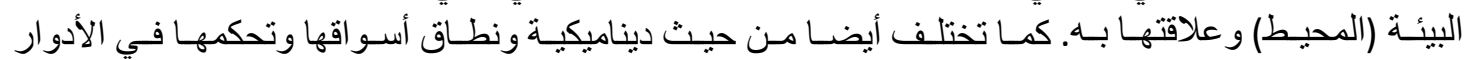

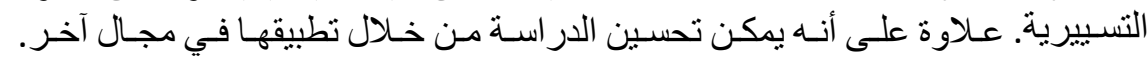

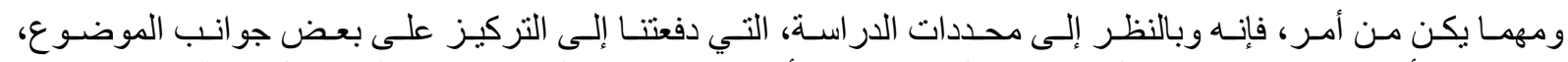

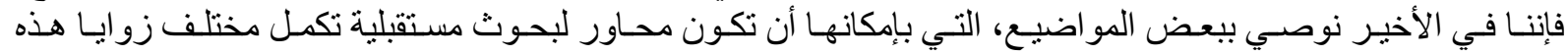

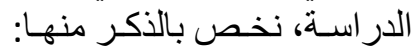

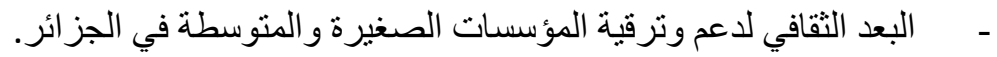

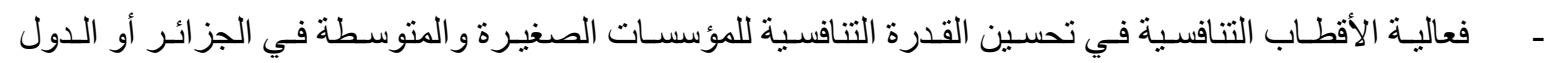

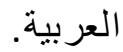

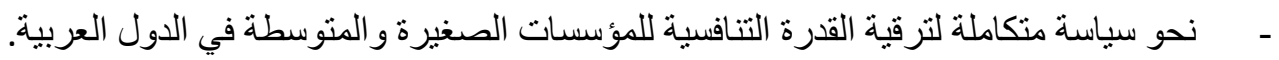

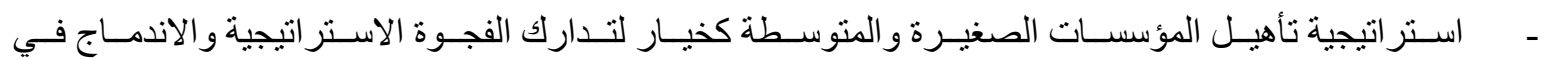
الاقتصــاد التنافسـي. 


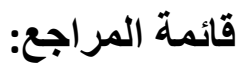

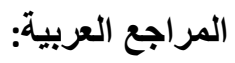

1. أبو زيد محمد خير (2010)، التحليل الإحصائسي للبيانـات باستخدام برمجـة SPS، ط 1، دار جريـر للنشـر، عمـان،

الأردن.

2. أحمد السيد كردي(2010) ، إدارة الموارد البشرية في منظمات الأعمال العصرية، مصر.

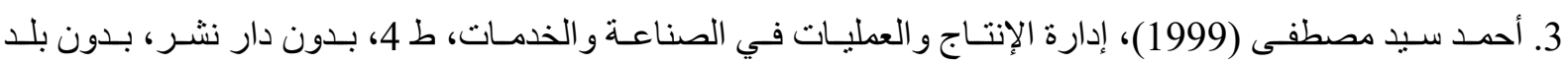

نثـر.

4. الدر ادكـة مأمـون، الثنبيلي طـارق (2002)، الجودة في المنظمـات الحديثة، ط 1، دار صفـاء للنشـر و التوزيـع، عمـان، الأردن.

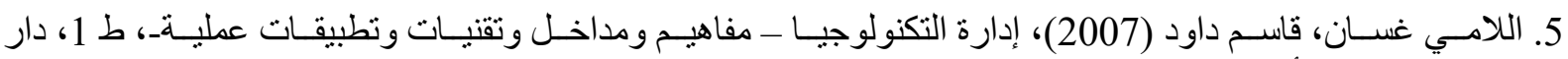
المناهـج، عمسان، الأردن.

6. المختـار حسن محمد أحمد محمد (2009)، الإدارة الإسـتر اتيجية المفاهيم و النـــاذج، الثـركة العربيـة المتحدة للتسـويق و والتوريدات، القاهرة، مصر.

7. الطائي محمد ، الخفاضـي نعمـة عبـاس خضيـر (2009)، نظم المعلومـات الإسـتر اتيجية منظـور الميزة الإسـتر اتيجية،

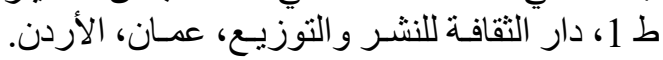

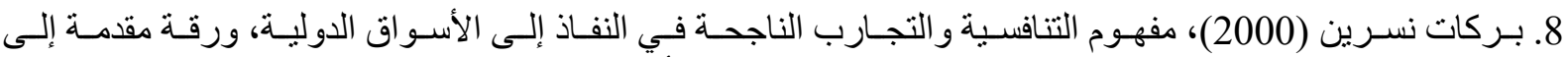

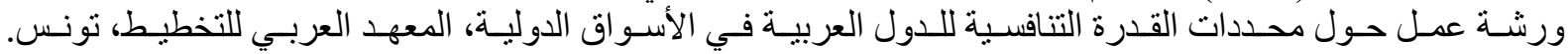

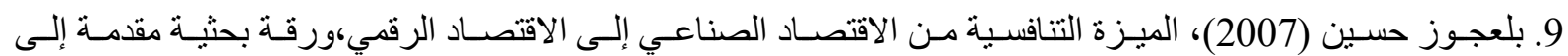

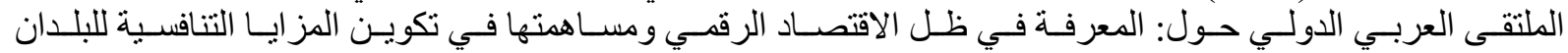

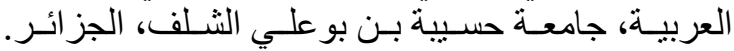

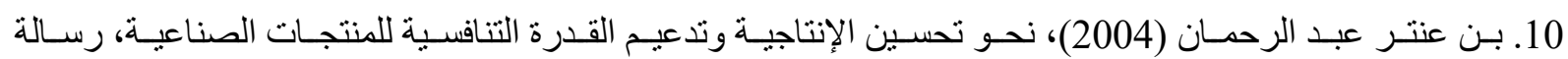

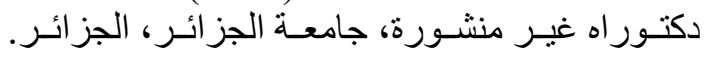

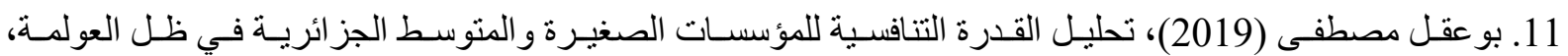

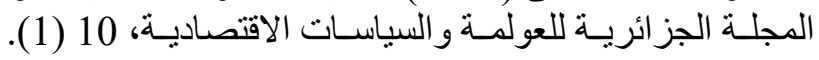

12. جوزيف بروكوبنكو (2000)، إدارة الإنتاجية، منظمة العمل الدولي، جنيف.

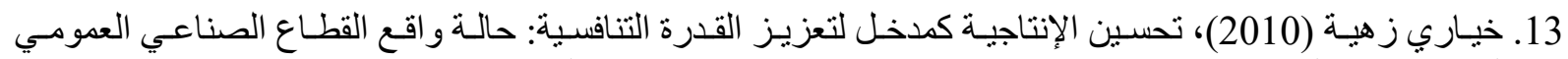

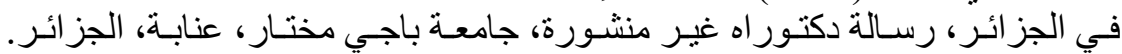

14. سامح عبد المطلب عامر (2011)، استراتيجيات إدارة الموارد البشرية، ط 1، دار الفكر للنشر والتوزيع، الأردن.

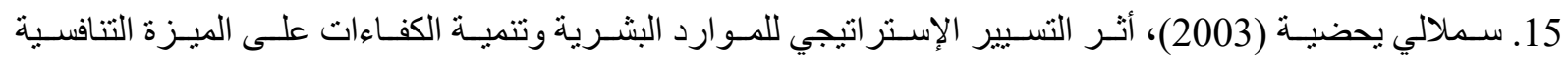

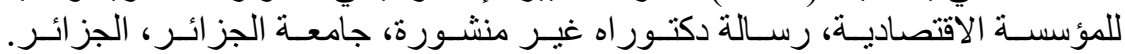

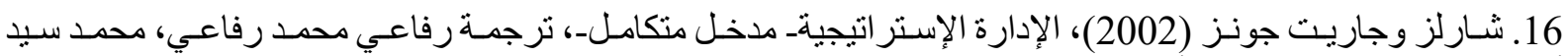

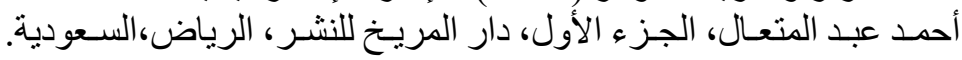

17. عطية طاهر مرسى (2001)، إدارة الأعمال الدولية، ط 1، دار النهضة العربية للنشر، بيروت، لبنان.

18. عبد الهادي سعيد (2002)، التسويق بمفهومه الجديد، دار قباء للنشر و التوزيع، مصر.

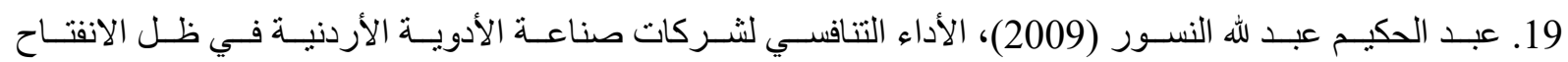

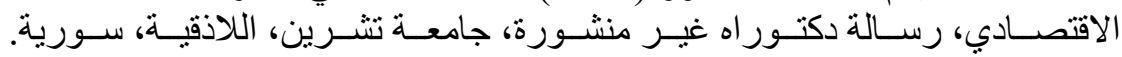




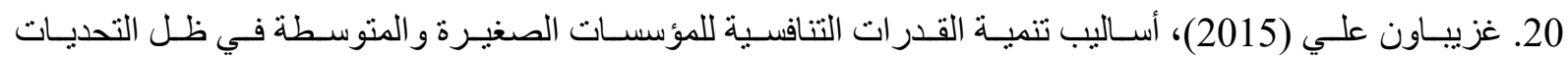

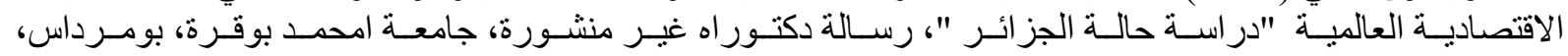
الجزائـر.

21. غـول فرحسات (2006)، مؤشـرات تتافسـية المؤسسـات الاقتصاديـة في ظـل العولمـة الاقتصاديـة، رسـالة دكتـور اه

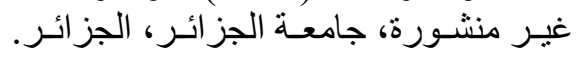

22. فـارس طـارق (2018)، دور ومكانـة المؤسسـات الصغيـرة والمتوسـطة وسـبل ترقيـة قدرتهـا التنافسـية، رسـالة

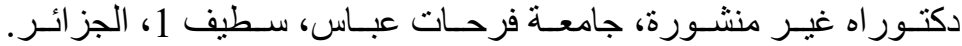

23. ماضي عادل (2007)، تطوير جودة المنتجات، ط 1، دار الكتب الجامعية، الإسكندرية، مصر.

24. مركز الصادرات العربية (2005)، تدعيم القدرات التنافسية للصادر ات العربية إلى الأسواق العالمية، قطر.

25. نبيـل محمــد مرســي (2006، اسـتر اتيجيات الإدارة العليـا (إعـداد، تتفيـذ، مر اجعـة)، المكتـب الجامعـي الحديــث،

الإسـكندرية، مصـر مرد.

26. نوري منير (2012)، نظام المعلومات لمطبق في التسبير، ط 9، ديوان المطبوعات الجامعية، الجزائر.

27. هويشـار معـروف (2006)، تحليـل الاقتصــاد التكنولوجـي، طـ 2، دار جريــر للنشـر والتوزيــع، عمـان، الأردن.

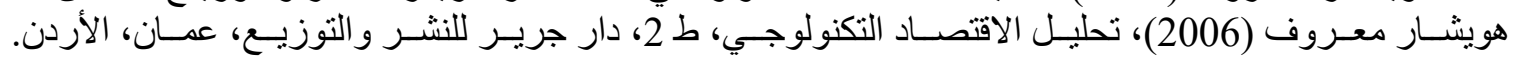

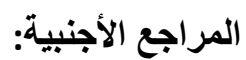

1. Abell, D,(1980), Defining The Business: The Strategic Planning, Prentice-Hall .

2. Cadden, M, \& Larid,B, Factors Affecting (1995), the Competitiveness of private sector In canada, USA.

3. Dahmani, A.M, (1996), Le partenariat et les alliances Stratégiques dans les nouvelles Politiques de développement des entreprises, Economie $N^{\circ} 36$, sans édition, sans pays d'édition, p20.

4. Fireman, J, (1994), Work Force and the Competitiveness, Fortune, Jun 24.

5. Labich, K, (1996), competitiveness in the Privet Sector, Fortune, USA, Sep 9.

6. Lincoln, David, (2002), Marketing and competitive Advantages, New York, USA.

7. Mores, Steven, (2006), Competitiveness Factors in Industrial Firms, Cogan Bidge.

8. Porter M.E, (1998), Competitive Advantage: Creating and Superior performance, Harvard.

9. Wheelen,T.L, Hunger J,D, (2004), Strategic Management and Business Policy, New jersey: Prentice Hall. 


\section{قائمة الملاحق}

\section{الاستبانة}

القسم الأول: معلومات شخصية

الرجاء وضع علامة (x) أمام الإجابة التي تراها مناسبة:

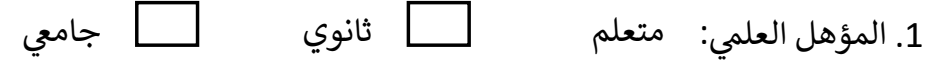

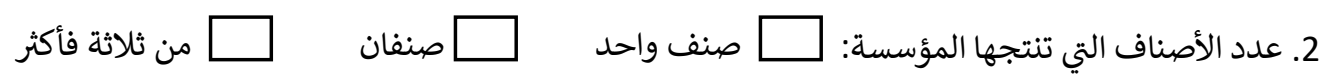

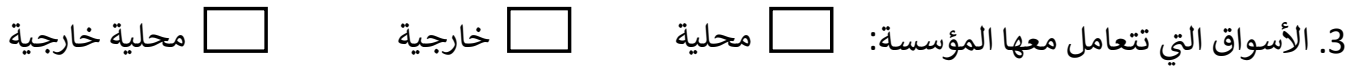

القسم الثاني: المعلومات الخاصة بالبحث

\begin{tabular}{|c|c|c|c|c|c|c|}
\hline موافق الإطلاق & موافيق & لا أدري & موافق & 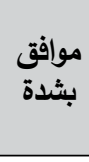 & السؤال & الرقم \\
\hline & & & & & \multicolumn{2}{|l|}{ أولا: عوامل تعزيز القدرة التنافسية للمؤسسات الصغيرة والمتوسطة } \\
\hline & & & & & للمؤسسـات المنتجات تعتبر عامسلا رئيسيا في تعزيز القدرة التتافسية & 01 \\
\hline & & & & & 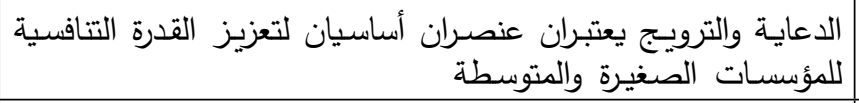 & 02 \\
\hline & & & & & التتافنولوجية المتقدمة والتجديد التكنولوجي دور كبير في زيادة القدرة & 03 \\
\hline & & & & & التتافيدية واختيار اللإستراتيجية التتافسية المناسبة يؤثر على القدرة & 04 \\
\hline & & & & & الصغيرة والمتوسطة البحث والتطوير يؤثر على القدرة التتافسية للمؤسسات & 05 \\
\hline & & & & & 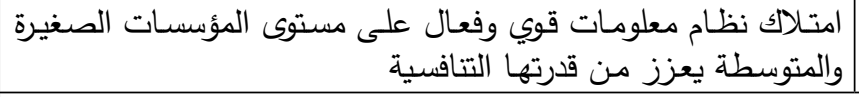 & 06 \\
\hline & & & & & \multicolumn{2}{|l|}{ ثانيا: دور وأهمية القدرة التنافسية للمؤسسات الصغيرة والمتوسطة في } \\
\hline & & & & & 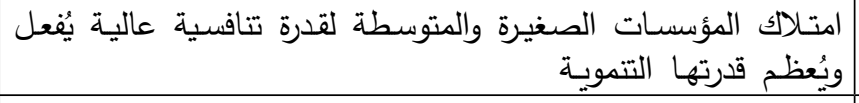 & 07 \\
\hline & & & & & | ومتوسطة تنافسي تعزيز القدرة التتافسية في تكوين قطاع مؤسسات صغيرة & 08 \\
\hline & & & & & 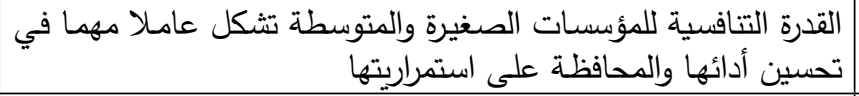 & 09 \\
\hline & & & & & فتشكل المؤسسات الصنية المخيرة والمتوسطة ذات القدرة التتافسية إستراتيجية & 10 \\
\hline
\end{tabular}


شريف، محي الدين

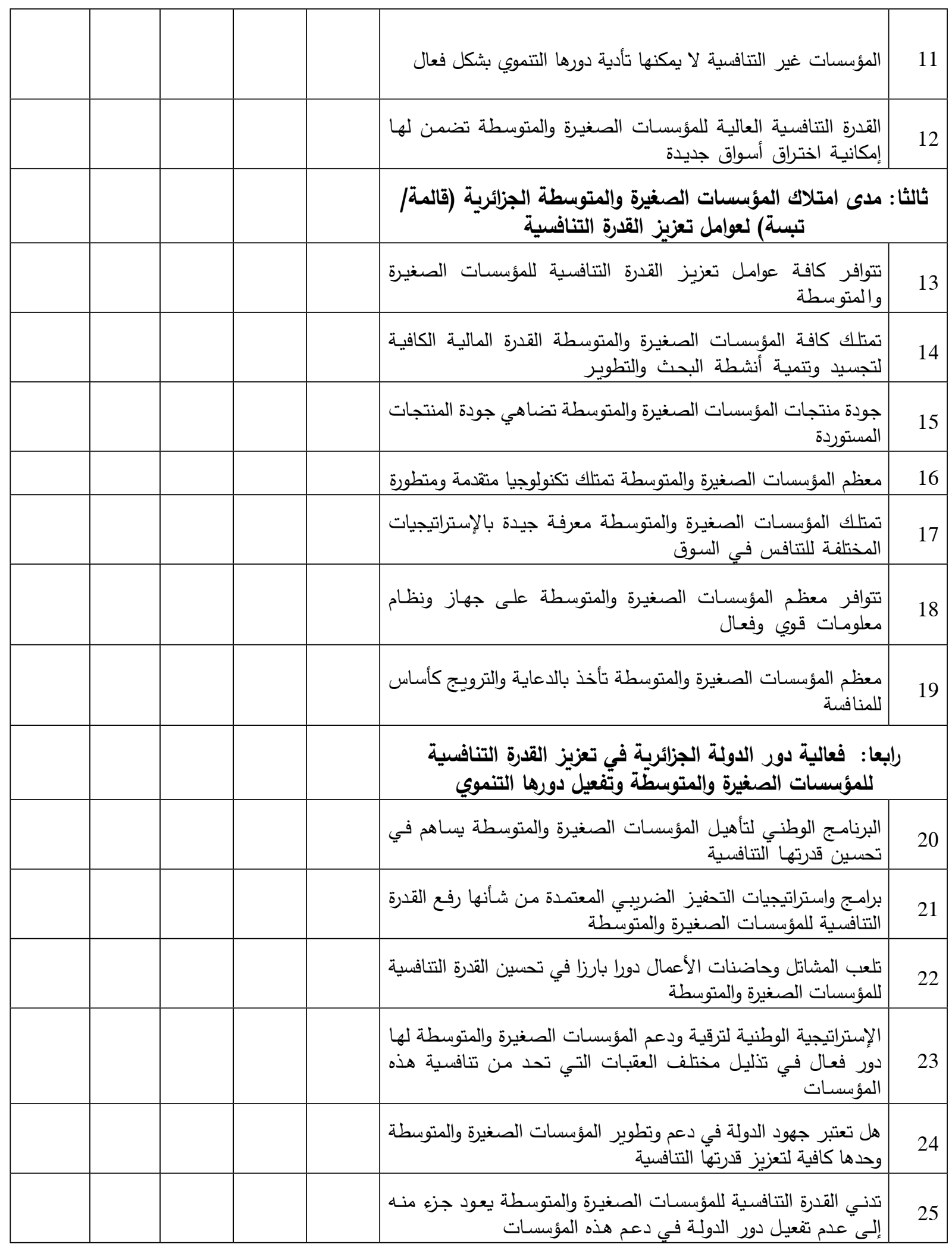

